\title{
On the Most Innovative Outer Access Structure of any Bantu Dictionary: The Lexique kikongo- français by Charles Polis (1938)
}

Gilles-Maurice de Schryver, KongoKing Research Group, Department of Languages and Cultures, Ghent University, Ghent, Belgium; and Department of African Languages, University of Pretoria, Pretoria, South Africa (gillesmaurice.deschryver@UGent.be)

\begin{abstract}
In this article a little-known dictionary manuscript from the 1930s, the Lexique kikongofrançais by the Jesuit missionary Charles Polis, is analysed in great detail. Section 1 expounds on the goal and raison d'être of the study, Section 2 introduces the manuscript, its author as well as the Kikongo variety dealt with, Section 3 presents the inner workings of the Lexique on macro-, microand mediostructural levels, Section 4 gives a lexicographical appreciation based on a large selection of the entries, Section 5 joins the international debate on the exact nature of a dictionary's macrostructure, access structure and access route, and Section 6 compares Polis's work with a dictionary from the same region and period. Conclusions are offered in Section 7 , chief among them the fact that Polis designed the most innovative outer access structure of any Bantu dictionary.
\end{abstract}

Keywords: BANTU, KIKONGO, KINTANDU, FRENCH, DICTIONARY MANUSCRIPT, BILINGUAL LEXICOGRAPHY, MISSIONARY LEXICOGRAPHY, LEMMA SIGN, MACROSTRUCTURE, OUTER ACCESS STRUCTURE, OUTER ACCESS ROUTE, INNOVATION

Samenvatting: Over de meest innovatieve externe toegangstructuur in de Bantoelexicografie: het Lexicon Kikongo-Frans van Charles Polis (1938). In dit artikel wordt een weinig bekend woordenboekmanuscript uit de jaren 1930, het Lexicon Kikongo-Frans van de jezuïet-missionaris Charles Polis, in detail onderzocht. Deel 1 licht het doel en de bestaansreden van de studie toe, Deel 2 introduceert het manuscript, zijn auteur, alsook de behandelde variant, Deel 3 beschrijft minutieus de macro-, micro- en mediostructuur van het Lexicon, Deel 4 geeft een lexicografische appreciatie die is gebaseerd op een ruime selectie van materiaal uit het werk, Deel 5 draagt bij tot het internationale debat over de ware aard van de macrostructuur, toegangstructuur en toegangsroute van een woordenboek, en Deel 6 vergelijkt Polis' werk met een woordenboek uit dezelfde regio en tijd. Conclusies worden aangeboden in Deel 7, de belangrijkste het feit dat Polis de meest innovatieve externe toegangstructuur uit de Bantoelexicografie ontwierp.

Sleutelwoorden: BANTOE, KIKONGO, KINTANDU, FRANS, WOORDENBOEKMANUSCRIPT, BILINGUALE LEXICOGRAFIE, MISSIONARISLEXICOGRAFIE, LEMMATEKEN, MACROSTRUCTUUR, EXTERNE TOEGANGSTRUCTUUR, EXTERNE TOEGANGSROUTE, INNOVATIE 


\section{Goal and raison d'être of the present study}

The main goal of this research article is to present and analyse an unpublished dictionary manuscript for Kikongo: the Lexique kikongo-français by Charles Polis s.j. (1885-†1943). Apart from the fact that this manuscript, of which there are still a handful of extant copies left, deserves to be widely known, what makes this work especially intriguing is that it employs a highly original outer access structure to get at the data. After a cursory examination of the work one could be forgiven to conclude that this is the first example of a Bantu dictionary in which the lexicographer has finally succeeded to atomise a Bantu language's lexicon, breaking it down to its most basic components, to then reassemble the lexicon (and to compile a dictionary in the process) from those building blocks. If this were indeed the case, this would be the first example of a purely stembased lemmatisation strategy in Bantu lexicography, rather than the traditional approach which results in a lemmatisation strategy that is neither purely stembased nor purely word-based, but sits somewhere on the sliding continuum between these two extremes (see De Schryver 2008: 86-88). Questions that immediately arise upon studying Polis's original presentation include:

- Could this outer access structure be applied to all Bantu languages?

- Is this outer access structure perhaps universal?

- Could such an outer access structure perhaps be a solution for all non-corpus-based lexicographic endeavours?

The latter question is a direct result of Polis's claim, in his introduction, that his approach allows for the systematic identification of the missing forms in a dictionary (Polis 1938: Part I, i). Regardless of the answers to these questions, a presentation of this work is important in its own right, as it contains - as will be argued below - a wealth of unique language data on a less-resourced Kikongo variety with a considerable time-depth (over 75 years, down to a century), which is rare in Bantu lexicography.

\section{The manuscript, its author and the Kikongo variety dealt with}

The manuscript consists of 719 typed-up pages, each page slightly larger in size than an A4. Polis, whose name appears on the bottom-right of the first page, 'transcribed' the material from his notes during the course of 1938, while in Leuven. ${ }^{1}$ His manuscript was stencil duplicated and distributed in nine fascicules (Van de Casteele 1968). ${ }^{2}$ It is not known how many copies were made. The Ghent University library has had the copy which used to belong to the agricultural engineer Lode De Wilde (whose name appears on the first page of each of the nine fascicules) for some time, and in 2015 also acquired the copy which used to belong to the missionary-linguists Jan Daeleman s.j. (1922†2014) and Gaston van Bulck s.j. (1903-†1966). 
The manuscript has no title page, which has resulted in a proliferation of designations. The copy of De Wilde was catalogued as Dictionnaire Kikongo (http://lib.ugent.be/catalog/rug01:000184510), while the Daeleman-Van Bulck one was catalogued as Dictionnaire KiKongo-Français, schikking van K. Polis (http://lib.ugent.be/catalog/rug01:002189704). Other copies that are known to us include a couple at the Leuven University library, where it is the Dictionnaire de la langue congolaise (http://www.unicat.be/uniCat?query=sysid:11277820), and one at the Antwerp University library, where it is the Dictionnaire congolais (en formation) (http://anet.be/record/opacanet/c:lvd:355728/N). We have chosen to refer to the work with Lexique kikongo-français, as done by Van de Casteele (1968) in his obituary of Polis, mainly because Polis himself points out in the introduction to his work that it is not yet a dictionary, but rather contains material that may lead to the compilation of a dictionary (Polis 1938: Part I, i). The Ghent University fascicules have been bound into three volumes, those at Leuven University into two, while at Antwerp University the catalogue entry shows nine 'volumes' (in all likelihood the nine fascicules). The version consulted for the present study is the one of De Wilde: the stencilled pages are generally of poor quality, often with faint vertical sections down the middle, and/or (mostly) horizontal ink smears. Several letters are also typed on top of one another, or are otherwise unreadable. With a bit of effort, these issues can of course be overcome (but they give even trained OCR software a hard time). During the binding of the De Wilde copy, on some pages a (very limited) number of lines at the bottom got cut off.

Even though there is no title page, we are certain the language dealt with is indeed Kikongo. This is amongst others clear from the illustrative material, which includes the phrases (1) to (4) - phrases that also tell us something about the process by which the material was collected: ${ }^{3}$

(1) FuM + O, VERBE (Part II, p. 251): ... tufuma ndiinga kikoongo, nous avons une masse (de travail) (dans cette étude) du kikoongo; donc bcp. à combiner, à réfléchir [we have a lot (of work) (in this study) of Kikongo; thus a lot to combine, to work out] ...

(2) FiK + OII, SUBST., mi (Part II, p. 261): ... ba balaanda beeto, sa bamona mmfiku, sa babaka kikoongo mu $\underline{m m f}$., ceux qui viendront après nous, trouveront la difficulté supprimée; ils acquerront le kikoongo sans peine, à bon compte (réflexion d'un aide) [those who will come after us, will find that the difficulty is gone; they will acquire Kikongo without efforts, on the cheap (remark of a helper)] ...

(3) KoZ \& KoS + OI, VERBE (Part II, p. 402): ... muundele ukoonza Na Kosi kikoongo, le Blanc est en train d'épuiser tout le kikoongo de Monsieur Kosi [the White man is busy exhausting all the Kikongo of Mr Kosi] ...

(4) KoZ \& KoS + OI, V.DER., uNA (Part II, p. 403): ... konzununa kikoongo, rechercher tout le kikongo mot par mot [research all of Kikongo, word after word] ...

What is thus immediately apparent from these four example phrases, is that Polis worked with native-speaker language consultants - one of them even 
called Mr Kosi - with whom he tried out all possible 'combinations' in an attempt to pinpoint all the words of Kikongo. Those informants felt that Polis was really getting the maximum out of them, and as a result they concluded that anyone wishing to learn Kikongo in the future would now have an easy time thanks to their efforts.

Knowing that one is dealing with Kikongo is not enough, however, as 'Kikongo' is actually "a disparate continuum of closely related Bantu languages" known as the Kikongo Language Cluster or 'KLC' (De Schryver et al. 2015). The KLC may be divided into four subgroups - North, West, East and South — together with a Central buffer zone, as shown in Figure 1.

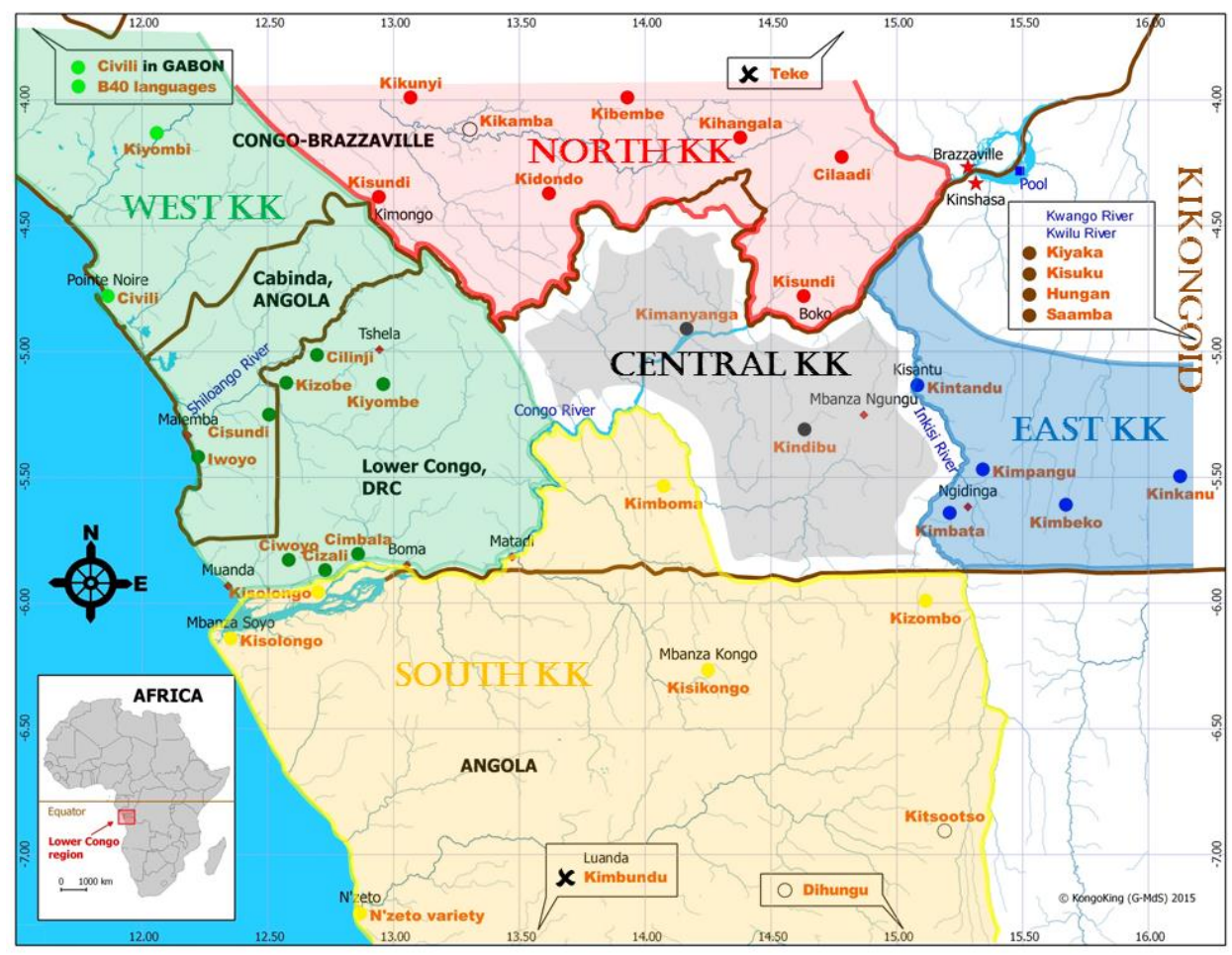

Figure 1: The Kikongo Language Cluster (KLC), with its sub-groups mapped. Colours indicate sub-group membership within the KLC. (Kimbundu and Teke are not part of the KLC, and are therefore preceded by black crosses.)

In order to determine to which subgroup the Kikongo variety described by Polis belongs, and perhaps even to pinpoint the variety itself, we can first turn to the literature. Over the past four years, the KongoKing research group has built up and digitised a documentation corpus which currently stands at over a 
thousand sources on the Kongo kingdom and/or on the Kikongo language. Disappointingly, Polis is only mentioned in seven sources: in the obituary already referred to, in the documentation of one map, in the introduction of one dictionary, in two MAs, in one $\mathrm{PhD}$, and in one scientific article.

From the obituary (Van de Casteele 1968) we learn that Charles Polis was born in Antwerp on November 1, 1885. As a Jesuit he arrived in the Kwango for missionary work on August 15, 1911, and basically stayed there for the rest of his life, being variously posted as a teacher/priest to Kimpako, Leverville, Lemfu, Mbanza-Mboma and Ngidinga. All of these locations are east of the Inkisi River, and all but one (Leverville, the present Lusanga) are close to that river, which thus strongly suggests that Polis is covering one (or several) East Kikongo varieties in his manuscript. Kimpako and Mbanza-Mboma are locations close to Kisantu, where Kintandu is spoken, while Lemfu is situated halfway between Kisantu and Ngidingi, the latter where Kimbata is spoken. See Figure 1 for the major locations, the Inkisi River, and the KLC varieties. Polis's stay in the Congo was interrupted four times for return visits to Belgium, the longest of these during the entire World War I. He died of health complications in a Léopoldville (today Kinshasa) hospital on June 27, 1943.

In the supporting documentation of Boone's (1973: 145) ethnographic map of the Congo, Polis is mentioned for a short contribution on the Mbata (Polis 1942). In contrast, in his dictionary Swartenbroeckx (1973: v) refers to "the excellent Kintandu works" of Polis which he was alas "not able to acquire in time" to help during compilation, while Makaya Lutumba (1999: 9) merely lists Polis together with René Butaye and Joseph Van Wing as contributors to Kintandu. In neither of these, references to actual works in Kintandu are however provided. Makolo Miaka (2000: 8), who clearly copied various pages verbatim from Makaya Lutumba (1999), repeats the exact same paragraph and thus statement regarding Kintandu. Lastly, and arguably the best evidence, Daeleman (1966) points out in his PhD on Kintandu:

Veel nut, inzonderheid bij de studie van de werkwoordafleidingen, hebben we getrokken van de rijke mijn van voorbeelden die amper aangeboord is in het als handschrift gestencilde 'Dictionnaire kikongo-français' van wijlen P. K. POLIS. [A great help, especially when it comes to the study of verbal derivations, was the goldmine of examples found in the hardly perused stencilled manuscript Dictionnaire kikongofrançais by the late Father C. POLIS.] (Daeleman 1966: 7)

In his article on the PB reflexes in Kintandu, Daeleman (1983) also refers to and uses data from Polis's manuscript. In the entire academic literature, then, there is but one scholar who explicitly refers to the work under study: Jan Daeleman, not surprisingly another Jesuit working from Leuven, who put the information contained within Polis's manuscript to good use in the course of his doctoral studies and subsequent research. Since then, Polis's work has regrettably remained untapped. The literature just reviewed further also suggests that the (main?) variety dealt with by Polis must be Kintandu. 
Could the Kikongo variety be derived from Polis's manuscript itself? A good starting point is to look at the (frequencies of) place names used in the illustrative material, ${ }^{4}$ which clearly favour Kisantu and neighbouring locations over Ngidinga: Kisantu $(25 \mathrm{x})$, Kimvulu $(12 \mathrm{x})$, Kimpese $(6 \mathrm{x})$, Lemfu $(4 \mathrm{x})$, Ngidinga $(3 \mathrm{x})$, Kimpako $(2 \mathrm{x})$, Kivuunda $(2 \mathrm{x})$, or Mbe (an old village close to Lemfu, $1 \mathrm{x}$ ). Also compare this to locations much farther away: Mpuumbu and Stanley Pool $(6 \mathrm{x})$ or San-Salvador/S. Salvador $(3 \mathrm{x})$. Rivers are not mentioned often enough to be conclusive, but are indicative: Inkisi $(1 \mathrm{x})$ and Bongolo $(1 \mathrm{x})$ vs. Congo $(0 \mathrm{x})$ and Kwilu $(0 \mathrm{x})$. While the Ntandu (East), Mpangu (East), Mbeko (East), Ndibu (Central), Zombo (South), Solongo (South) and Laari (North) are each mentioned about once or twice, the Mbata (East) are mentioned numerous times. Further analysis reveals that this is actually done to contrast the speech of the Mbata, mostly labelled with the abbreviation $M B$., with the main variety covered in the manuscript. There are well over 180 instances of the labels $M B$. and Mbata throughout the microstructure. Additionally, a note at the start of fascicule $\mathrm{G} / \mathrm{K}$ - is very clear on the fact that Kimbata should be considered the dialectal form in this manuscript:

(5) G/K- (Part II, p. 293): Nota: le sigle (MB.g) indique que le g est maintenu dans le dialecte de Mbata, qui le remplace généralement par v bilabial. [Note: the label 'MB.g' indicates that $g$ is maintained in the dialect of Mbata, where it is generally replaced by the bilabial v.]

While the linguistic explanation is only approximate here, this note does point out an important difference between Kintandu and Kimbata regarding the phonetic outcome of the PB ${ }^{*} \mathbf{p}$ in intervocalic position, as seen in (6) vs. (7): ${ }^{5}$

(6) Kintandu

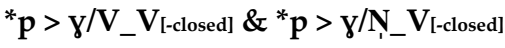

$$
\begin{aligned}
& \text { *-páan- 'give' (BLR 2345) > -yáán- }
\end{aligned}
$$

(Daeleman 1983: 382)

\section{Kimbata}

$$
\begin{aligned}
& { }^{*} \mathbf{p}>\mathbf{v} / \mathbf{V}_{-} \mathbf{V}_{\text {[-closed] }} \&{ }^{*} \mathbf{p}>\mathbf{v} / \mathbf{Y} \_V_{\text {[-closed] }} \\
& { }^{*} \text {-páan- 'give' (BLR 2345) }>\text {-vana }
\end{aligned}
$$

As shown in Bostoen et al. (2013: 63-66), given $\beta, \mathbf{v}, \mathbf{h}, \stackrel{\circ}{\mathrm{\gamma}}$ and $\mathrm{y}$ are all found as unconditioned reflexes of $\mathrm{PB}{ }^{*} \mathbf{p}$ within the KLC, these phonetic outcomes may be seriated most economically by postulating the intermediate proto-sound ${ }^{\circ} \phi$, as shown in (8):

$$
\begin{aligned}
& \text { *p-lenition within the KLC } \\
& \begin{array}{lllllll}
* \mathrm{p} & > & \boldsymbol{\beta} & > & \mathbf{v} & & \\
& > & \mathbf{h} & > & \circ & & \\
& > & \mathrm{\gamma}
\end{array}
\end{aligned}
$$


Kintandu, then, is the endpoint of the bottom series of the split seriation shown in (8), while Kimbata is the endpoint of the top series. Polis covers the forms of the bottom series, thus Kintandu.

Other KLC varieties that are labelled in Polis's manuscript include the southern Kisikongo, as Kis. $(63 \mathrm{x})$, and Kizoombo $(2 \mathrm{x})$, as well as the western Kiyombe, as May. (22 x). There are even a few instances of the Kikongoid Kiyaka $(10 \mathrm{x})$, and the non-related eastern Kiluba/Luba $(2 \mathrm{x})$. In order to contrast 'his Kikongo' with other KLC varieties, Polis must have had access to other existing dictionaries, as he is not known to have travelled widely throughout the Lower Congo region, and thus to have had first-hand experience with other KLC varieties. That he indeed had access to other reference works is evidenced by the fact that he names his colleagues and thus indirectly his sources by name: Laman/Lam. $(23 \mathrm{x})$, Bittremieux $(1 \mathrm{x})$, Butaye $(1 \mathrm{x})$, Gillet $(1 \mathrm{x})$, Georges de Gheel $(1 \mathrm{x})$, Bentley $(1 \mathrm{x})$, and Delplace $(1 \mathrm{x})$. These can be linked to dictionaries for the central Kimanyanga variety by Laman (1936), the western Kiyombe variety by Bittremieux $(1922,1927)$, the eastern Kintandu variety by Butaye (1909) and Gillet and Pâque (1910), the southern Kisikongo variety by Van Gheel $(1652)^{6}$ and Bentley $(1887,1895)$, and the concocted Kikongo by Delplace (1895). All of these reference works indeed appeared before 1938. The gleaned information was in such cases mostly literally lifted from those other sources, as is for instance the case for the excerpt shown in (9) with data copied from and cross-referenced to (10):

(9) SuS + OII, SUBST., ma (Part II, p. 144): ... dinsusu-nsusu, légume apprécié (ocimum sp., petit basilic à feuilles aromatiques servant aux assaisonnements; sec. Fr Gillet) [much-liked vegetable (ocimum sp., small basil with aromatic leaves used to season; according to Brother Gillet)] ...

Dinsusu. - Ocimum sp.

LABIÉES.

Nsusu $=$ poule (generice).

Petit basilic, à feuilles aromatiques servant aux assaisonnements.

(Gillet and Pâque 1910: 14)

While it is a truism that one cannot prove a negative, the total absence of labels to mark Kintandu, in combination with the fact that other varieties are labelled and contrasted with what is being described lexicographically, should be sufficient additional proof that Polis indeed deals with Kintandu.

The only other known sizeable general-language dictionary for Kintandu is Butaye's (1909) Dictionnaire kikongo-français, français-kikongo. Even though that dictionary was published three decades before Polis transcribed his material (it was even published before Polis ever set foot in the Congo), we can be rather certain that Polis did not frequently consult Butaye's dictionary to compile his own work. This assertion is not only based on Polis's idiosyncratic approach to the macrostructure, but also on the actual coverage of the lexicon in his work, the original microstructural contents he presents, and his use of a 
non-standard spelling for Kikongo/Kintandu. Certainly, a valid hypothesis could have been that Polis merely 'pretended' to be devising a new outer access structure, while he was in actual fact rearranging the data of an existing dictionary (including the possibility of the rearrangement of the draft of a dictionary of his own making). This hypothesis is inspired by the fact that it seems rather overwhelming, truth must be told, to imagine a situation whereby one departs from the most basic building blocks of a language $-\mathrm{CV}(\mathrm{C})$ clusters in this case - which are subjected to some systematic manipulations and the addition of other building blocks, the results of which are only kept when meaningful words are the outcome, to end up with a balanced and representative coverage of a language's lexicon. Can this type of introspection really lead to the full coverage of the lexicon - or at any rate, an acceptable one? As we will show in the subsequent sections, this is indeed possible, and the dictionary compilation procedure gleaned from the extracts shown in (1) to (4) must therefore reflect reality: Polis and his team of native speakers pulled off quite a feat.

\section{Presentation of Polis's Lexique}

\subsection{The macrostructure of the Lexique}

\subsubsection{Metalexicographical context}

It is well-known that modern dictionaries for the Bantu languages are corpusbased (De Schryver and Prinsloo 2000a, b), with the very best even aiming to be corpus-driven (De Schryver 2010). In the pre-corpus era the main strategies employed for the actual compilation of the macrostructure were either (i) random, (ii) rule-oriented, or (iii) enter-them-all approaches. In the random approach "words are simply added whenever they happen to cross the compiler's way", in the rule-oriented approach "a set of rules/guidelines presented in the dictionary's front matter must be followed whenever a word cannot be looked up directly" (so the assumption is that everything is covered 'in theory'), and in the enter-them-all approach "the compilers are obsessed to include all conceivable nominal and verbal derivations [working] through a modular paradigm in order to pursue such a comprehensiveness" (De Schryver and Prinsloo 2001: 219-225).

This is not to say that still other strategies have not been tried out. Prinsloo and De Schryver (1999: 264-267) discuss an interesting case whereby Vermeersch (1922) sought out and brought together the vocabulary of Cilubà according to morpho-lexical fields. This approach has been found wanting (Kalonji 1993: 134-136), and may be seen as a variant of the random approach in that there is no system to ensure a systematic coverage. A more recent alternative approach is that by Mbatha (2006) for Zulu, who argues that only content words belong in a dictionary and that just four word classes merit to be recog- 
nised anyway: nouns, verbs, interjections, and ideophones. This could be seen as a variant of the rule-oriented approach, whereby all sorts of meanings now somehow have to be forced onto extremely low-frequent to non-existing verb and noun stems in order to fit in, say, what everyone else recognises to be adjectives, adverbs, etc. For a critique of Mbatha's method, with supporting examples, see De Schryver and Wilkes (2008: 829-830). Polis's approach, now, may be seen as a variant of the enter-them-all approach, also known as the paradigm approach, but unlike the blind generation of often highly infrequent, dubious and even non-existent forms that characterise other modular approaches (see Prinsloo 2014), Polis was only interested in what really exists (and in all openness even added question marks when he was uncertain).

\subsubsection{The Vertical Base}

So how is Polis's Lexique structured on the macrostructural level? To begin with, one needs to acquaint oneself with his alphabetical ordering for consonants (11) and vowels (12):

(11) Consonants

B/P, M, V/F, G/K, D L/T, N, Z/S (, Y, W)

(12) Vowels

a, e, i, o, u (, diphthongs)

As may be seen from (11), Polis first works through the labials (bilabials $B / P$ and $\mathrm{M}$, and labiodentals $\mathrm{V} / \mathrm{F})$, then the velars $(\mathrm{G} / \mathrm{K})$, followed by the alveolars $(\mathrm{D} \sim \mathrm{L} / \mathrm{T}, \mathrm{N}$ and $\mathrm{Z} / \mathrm{S}$ ), and concludes with the semi-vowels $(\mathrm{Y}$ and $\mathrm{W})$. The consonants are thus grouped according to place of articulation (mostly from front to back), and within each group according to manner of articulation (from plosive over nasal, etc.). At each of those levels Polis considers the voiced ones before the unvoiced ones (where relevant). D and L are considered on a par, as they are in complementary distribution in Kintandu. The vowels, shown in (12), follow the standard ordering.

In a first stretch of his manuscript Polis combines each consonant (C) with either a following vowel (-) or a following vowel and itself, as shown in (13), going through all the consonants in his defined ordering (11), and associating each of the vowels in the standard ordering (12) to each of the consonants, one at a time:

$$
\text { C-C }
$$

An extract from the resulting ordering may be seen in (14): 
(14) ... Pa, Pe, Pi, Po, Pu, PaP, PeP, PiP, PoP, PuP, Ma, Me, Mi, Mo, Mu, MaM, MeM, MiM, MoM, MuM, ... Sa, Se, Si, So, Su, Sau, Say, SaS, SeS, SiS, SoS, SuS. (The semi-vowels $\mathrm{Y}$ and $\mathrm{W}$ are not considered here.)

Voiced and unvoiced renderings are treated on a par, before moving to the next consonant. Furthermore, given that $\mathrm{D}$ and $\mathrm{L}$ are in complementary distribution, this means that to for example go from $\mathrm{DaD}$ to $\mathrm{DeD}$ to $\mathrm{DiD}$ etc. one needs quite some gymnastics, as illustrated in (15):

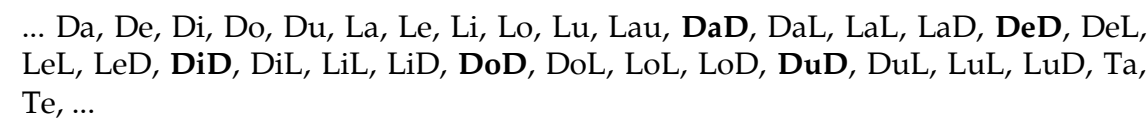
LeL, LeD, DiD, DiL, LiL, LiD, DoD, DoL, LoL, LoD, DuD, DuL, LuL, LuD, Ta, $\mathrm{Te}, \ldots$

In a second stretch Polis combines each consonant (C) with each other consonant $\left(\mathrm{C}^{\prime}\right)$, as shown in (16), running through all the vowels before going to the next consonant:

(16) $\quad \mathbf{C}^{\prime} \mathrm{C}^{\prime}$

This results in the ordering seen in (17):

(17) B-P (an empty category), PaB, PeB, PiB, PoB, PuB, BaM, BeM, BiM, BoM, BuM, PaM, PeM, ... SaT, SeT, SiT, SoT, SuT, ZaN, ZeN, ZiN, ZoN, ZuN, SaN, SeN, SiN, SoN, SuN, ZaS \& SaZ, ZeS \& SeZ, ZiS \& SiZ, ZoS \& SoZ, ZuS \& SuZ. (The semivowels $\mathrm{Y}$ and $\mathrm{W}$ are not considered here.)

For D L one now obtains sequences like (18):

(18) ... PaK, PeK, PiK, PoK, PuK, BaD, BaL, BeD, BeL, BiD, BiL, BoD, BoL, BuD, BuL, BaT, BeT, BiT, BoT, BuT, PaD, PaL, PeD, PeL, ...

While all of this is of an impeccable logic, this ordering is of course not userfriendly. Do note that this was not meant to be, as this work is only a temporary tool for Polis, so the usual dictionary criticism is not warranted. At the same time, Polis did get tangled up in his own system as he starts his dictionary with the sequence shown in (19)a, while it should have been as in (19)b:

(19) a. $\mathrm{Ba}, \mathrm{BaB}, \mathrm{Be}, \mathrm{BeB}, \mathrm{Bi}, \mathrm{BiB}, \mathrm{Bo}, \mathrm{BoB}, \mathrm{Bu}, \mathrm{BuB}, \ldots$

b. $\mathrm{Ba}, \mathrm{Be}, \mathrm{Bi}, \mathrm{Bo}, \mathrm{Bu}, \mathrm{BaB}, \mathrm{BeB}, \mathrm{BiB}, \mathrm{BoB}, \mathrm{BuB}, \ldots$

The difference is not insignificant, as the sequence shown in (19) runs over 25 pages. Overall, there are very few other errors in the actual ordering (the headings are sometimes wrong though). Also, some categories are lumped together, as may be seen from the ampersand ' $\&$ ' in (17). At times, this leads to slip ups: there is for instance an entry for $\mathrm{GaD}$, and another for $\mathrm{GaL} \& \mathrm{GaD} .^{7}$ 
In a third stretch Polis specifically deals with the semi-vowels $\mathrm{Y}$ and $\mathrm{W}$, as well as the diphthongs. For Y, formulas (20) and (21) are applicable, which results in the sequence shown in (22):

(20) Y-

Y-Y

(21) $\quad \mathrm{Y}-\mathrm{C}, \mathrm{W}$

C-Y

(22) Ya, Ye, Yi, Yo, Yu, YaY, YeY, YiY, YoY, YuY, YaB, YeB, YiB, ... YoZ \& YoS, YuZ \& YuS, YaW, BaY, BeY, BiY, BoY, PaY, PeY, PiY, PoY, PuY, MaY, MeY, MiY, ... ZaY, ZeY, ZiY, ZoY, ZuY, SaY, SeY, SoY, SuY.

Likewise for $\mathrm{W}$, formulas (23) and (24) are applicable, which results in the sequence shown in (25):

(23) W-

$$
\mathbf{W}-\mathbf{W}
$$

(24) W-C

\section{$\mathrm{C}-\mathrm{W}$}

(25) Wa, We, Wo, Wu, WaW, WeW, WiW, WoW, WuW, WaB, WeB, WiB, ... WoZ \& WoS, WuZ \& WuS, BaW \& PaW, BeW \& PeW, ... DoW \& LoW, DuW \& LuW, TaW, ToW, Z-W, S-W.

The sequence for the diphthongs (26) is as shown in (27):

(26) VV

(27) ay, au (monosyllabic), au (polysyllabic), ey, eu, oy.

Clearly, not all combinations exist, and when one doesn't, Polis normally does not provide a heading for it, as may be deduced from the gaps in the sequences seen in (22) and (25). When treating each vowel in its own right is not worth the effort, Polis also lumps the material, as is the case for Z-W and S-W in (25). Again, very few errors were found in the sequence, except that an entry $Y-W$ follows SuY, while that entry should actually have replaced (and the data merged with) the earlier YaW (which follows YuZ \& YuS).

Finally, there is also a shorter zeroth stretch, which precedes the three stretches already mentioned, where Polis lists what he calls the 'pre-grammatical forms'. The ordering here mimics the ordering used in stretches one to three, thus first (13) and then (16), presented as (28) and (29). This is followed by a section dedicated to vowels and varia (30), sections on $W$, as (31) rather than (23) and (24), and Y, as (32) rather than (20) and (21), and concludes with a section on diphthongs (33): 
(28) C-

C-c

(29) $\mathrm{C}-\mathrm{c}^{\prime}$

(30) V, varia

(31) W-

$\mathrm{W}-\mathrm{c}, \mathrm{w}, \mathrm{y}$

C-w

(32) Y-

Y-c

C-y

Y-y

(33) VV

Following Polis, the second consonant in the pre-grammatical part has been written in lowercase (although he doesn't follow this convention consistently), which should ease in differentiating this part from the rest of the work. By and large, one notices that the pre-grammatical part thus follows the same sequence as the rest of the work, but not in the details. In addition to the swapping of the semi-vowel sections $\mathrm{Y}$ and $\mathrm{W}$, the changes within those sections, and the addition of a vowel section, the pre-grammatical equivalent of (15), for instance, is also different, as shown in (34):

(34) ... Kik, Kok, Kuk, Da, De, Di, Do, Du, La, Le, Li, Lo, Lu, Dad, Ded, Did, Dod, Dud, Dal, Del, Dil, Dol, Dul, Lal, Lel, Lil, Lol, Lul, Lad, Led, Lid, Lod, Lud, Ta, $\mathrm{Te}, \ldots$

There are also a few errors, such as the erroneous placement of the F- sequence before the $\mathrm{V}-\mathrm{v}$ sequence, where it should be the reverse.

For all these reasons, and in order to make this first level of the macrostructure more accessible to future users, we felt that it was necessary to create an index of the full $\mathrm{CV}(\mathrm{C})$ sequence. We have termed that sequence the 'Vertical Base', where even the shorthand ' $\mathrm{CV}(\mathrm{C})$ sequence' is an approximation, as it refers to the sequence of formulas (28), (29), (30), (31), (32), (33), (13), (16), (20), (21), (23), (24), and (26). The result is shown in Addendum 1. In perusing Polis's manuscript, checking and searching (the electronic version of) Addendum 1 greatly speeds up the look-up process.

We are now in a position to make more sense of the different fascicules of the manuscript, as summarised in Table 1. The short introduction (numbered i-iii by Polis) together with the pre-grammatical forms (numbered 1-67, including one bis-page), constitutes one fascicule. All the subsequent sections (for which the page numbering restarts at 1 , running up to 646 , including two bis- 
pages) each constitute a fascicule in their own right. Given the double numbering, we use Part I to refer to the pre-grammatical part, and Part II to refer to the bulk of the work. The dates in the manuscript indicate that Polis first transcribed the simple and double labials and linguals (fascicules 1 and $2-$ corresponding to Stretch 1 of his $\mathrm{CV}(\mathrm{C})$ sequence), followed by the introduction and pre-grammatical forms (fascicule 3 - Stretch 0 ). He then proceeded with all the mixed consonants (fascicules 4 to 8 - Stretch 2), and concluded with the semivowels and diphthongs (fascicule $9-$ Stretch 3 ).

Table 1: Details of the nine fascicules of Polis's Lexique, linked to the four different $\mathrm{CV}(\mathrm{C})$ stretches of the macrostructure's Vertical Base

\begin{tabular}{lllllll}
\hline No. & Title & Pp. & Fasc. Stretch & Part & Signed \\
\hline 0 & Introduction & i-iii & 3 & - & - & 24 Apr. 1938 \\
1 & Pre-grammatical forms & $1-67$ & $"$ & 0 & Part I & 21 May 1938 \\
2 & Simple \& double labials & $1-80$ & 1 & 1 & Part II 21 March 1938 \\
3 & Simple \& double linguals & $81-144$ & 2 & $"$ & $"$ & 17 Apr. 1938 \\
4 & B/P with other consonants & $145-225$ & 4 & 2 & $"$ & 26 Aug. 1938 \\
5 & M and V/F with other consonants & $226-292$ & 5 & $"$ & $"$ & 2 Sept. 1938 \\
6 & G/K with other consonants & $293-406$ & 6 & $"$ & $"$ & 10 Sept. 1938 \\
7 & D L/T with other consonants & $407-495$ & 7 & $"$ & $"$ & 20 Sept. 1938 \\
8 & N and Z/S with other consonants & $496-599$ & 8 & $"$ & $"$ & 25 Sept. 1938 \\
9 & Words with Y, W and diphthongs & $600-646$ & 9 & 3 & $"$ & 9 Oct. 1938 \\
\hline
\end{tabular}

The information summarised in Table 1 and the $\mathrm{CV}(\mathrm{C})$ sequence shown in Addendum 1 constitute the first entry point to (and the first part of the macrostructure of) Polis's work. Addendum 1 reveals that there are $1592 \mathrm{CV}(\mathrm{C})$ clusters: these, then, are the basic building blocks around which Polis proceeds to construct the entire lexicon of Kintandu. Except for a few empty $\mathrm{CV}(\mathrm{C})$ clusters, for which the heading is listed but no data is provided, each of those clusters is now subjected to a number of manipulations in order to arrive at real words.

\subsubsection{The Horizontal Base}

Still on the macrostructural level, Polis follows up with three types of manipulations of each CV(C) cluster in Part II: Steps 1, 2 and 3 - to which we will collectively refer to with the term 'Horizontal Base'. To enable the presentation of Step 1, each $C V(C)$ cluster may now be written as shown in (35):

$$
\begin{aligned}
& \mathrm{C} \mathrm{V} \\
& \mathrm{C}_{1} \mathrm{~V} \mathrm{C}_{2}
\end{aligned}
$$


Step 1 is concerned with either the palatalization or labialization of the first consonant ( $\mathrm{C}$ or $\mathrm{C} 1)$ and/or the prenasalization of the second consonant $(\mathrm{C} 2$, or for the $\mathrm{CV}$ cluster simply the consonant $\mathrm{C}$ ). Considering either the presence of palatalization (coded $\mathrm{Y}$ ), the presence of labialization $(\mathrm{W})$, or the absence of both $(\mathrm{O})$, in combination with either the presence (I) or absence (II) of prenasalization, results in a $3 \times 2$ matrix, or thus six possibilities, for which Polis uses the codes shown in the column 'Code 2' of Table 2. The linguistic implication of those codes is shown in the last two columns of Table 2, where the superscript ${ }^{j}$ stands for palatalization, the superscript ${ }^{\mathrm{w}}$ for labialization, and the superscript ${ }^{\mathrm{N}}$ for prenasalization (with $\mathrm{N}$ a non-syllabic homorganic nasal). Optional items are shown between round brackets; variation within the options is separated by a comma.

Table 2: Step 1 of the Horizontal Base in Polis's Lexique

\begin{tabular}{|c|c|c|c|c|c|}
\hline Code & Code & Meaning & Linguistic & orr & nula \\
\hline$\underline{1}$ & 2 & & $\mathrm{CV}$ & & CVC \\
\hline Y & & palatalization of $C$ or $C_{1}$ & ${ }^{(\mathrm{N})} \mathrm{C}^{\mathrm{j}} \mathbf{V}$ & | & $\mathbf{C}_{1}^{\mathrm{j}} \mathbf{V}^{(\mathrm{N})} \mathbf{C}_{2}$ \\
\hline & YI & $\begin{array}{l}\text { palatalization of } C \text { or } C_{1} \text {, } \\
\text { and prenasalization of }[C \text { or }] C_{2}\end{array}$ & {$\left[{ }^{\mathrm{N}} \mathrm{C}^{\mathrm{j}} \mathrm{V}\right]$} & | & $\mathbf{C}_{1}^{\mathrm{j}} \mathbf{V}^{\mathrm{N}} \mathbf{C}_{2}$ \\
\hline & YII & $\begin{array}{l}\text { palatalization of } C \text { or } C_{1} \text {, } \\
\text { but no prenasalization of [C or] } C_{2}\end{array}$ & {$\left[\mathrm{C}^{\mathrm{j}} \mathbf{V}\right]$} & | & $\mathrm{C}_{1}^{\mathrm{j}} \mathrm{V} \mathrm{C}_{2}$ \\
\hline $\mathrm{W}$ & & labialization of $C$ or $C_{1}$ & ${ }^{(\mathrm{N})} \mathrm{C}^{\mathrm{w}} \mathbf{V}$ & | & $\mathrm{C}_{1}{ }^{\mathrm{W}} \mathbf{V}^{(\mathrm{N})} \mathrm{C}_{2}$ \\
\hline & WI & $\begin{array}{l}\text { labialization of } C \text { or } C_{1} \text {, } \\
\text { and prenasalization of }[C \text { or }] C_{2}\end{array}$ & {$\left[{ }^{\mathrm{N}} \mathbf{C}^{\mathrm{W}} \mathbf{V}\right]$} & | & $\mathbf{C}_{1}{ }^{\mathrm{w}} \mathbf{V}^{\mathrm{N}} \mathbf{C}_{2}$ \\
\hline & WII & $\begin{array}{l}\text { labialization of } C \text { or } C_{1} \\
\text { but no prenasalization of [C or] } C_{2}\end{array}$ & {$\left[C^{\mathrm{w}} \mathbf{V}\right]$} & | & $\mathbf{C}_{1}^{\mathrm{w}} \mathbf{V} \mathbf{C}_{2}$ \\
\hline $\mathrm{O}$ & & $\begin{array}{l}\text { no palatalization nor labialization of } \mathrm{C} \\
\text { or } \mathrm{C}_{1}\end{array}$ & ${ }^{(\mathrm{N})} \mathrm{C} \mathrm{V}$ & 1 & $\mathbf{C}_{1} \mathbf{V}^{(\mathrm{N})} \mathbf{C}_{2}$ \\
\hline & OI & $\begin{array}{l}\text { no palatalization nor labialization of } C \\
\text { or } C_{1} \text {, but with prenasalization of }[C \text { or }] C_{2}\end{array}$ & {$\left[{ }^{\mathrm{N}} \mathrm{CV}\right]$} & | & $\mathbf{C}_{1} \mathbf{V}^{\mathrm{N}} \mathbf{C}_{2}$ \\
\hline & OII & $\begin{array}{l}\text { no palatalization nor labialization of } \mathrm{C} \\
\text { or } \mathrm{C}_{1} \text {, and no prenasalization of [C or } \mathrm{C}_{2}\end{array}$ & {$[\mathrm{CV}]$} & | & $\mathrm{C}_{1} \mathbf{V} \mathrm{C}_{2}$ \\
\hline I & & prenasalization of $[\mathrm{C}$ or $] \mathrm{C}_{2}$ & {$\left[{ }^{N} \mathbf{C}^{(j, w)} \mathbf{V}\right]$} & & $\mathbf{C}_{1}{ }^{(j, w)} \mathbf{V}^{\mathrm{N}} \mathbf{C}_{2}$ \\
\hline II & & no prenasalization of [C or] $\mathrm{C}_{2}$ & {$\left[\mathbf{C}^{(j, w)} \mathbf{V}\right]$} & 1 & $\mathbf{C}_{1}^{(j, w)} \mathbf{V ~} \mathbf{C}_{2}$ \\
\hline
\end{tabular}

Analysis of the manuscript reveals that Polis also uses the codes shown in the column headed by 'Code 1', thus focusing on the palatalization (Y), labialization $(\mathrm{W})$, or absence of both $(\mathrm{O})$, as well as the prenasalization (I) or absence 
thereof (II), without considering (or specifying) the other level. The use of the single codes $\mathrm{Y}, \mathrm{W}$ and $\mathrm{O}$ is the favoured (but not the sole) approach for $\mathrm{CV}$ clusters, the use of the single codes I and II is the favoured (but not the sole) approach used in the semi-vowel-initial section of the third Stretch, while the use of the double codes (YI, YII, WI, WII, OI and OII) is the favoured (but not the sole) approach in the bulk of the work, thus for the CVC clusters. Not all Codes are used with each $\mathrm{CV}(\mathrm{C})$ cluster; only the applicable ones, and in the order seen in Table 2, from top to bottom.

The codes for the formulas shown between square brackets in the penultimate column of Table 2, namely those to indicate whether or not there is prenasalization of $\mathrm{CV}$ clusters, could have been used, but they haven't. Not only does Polis not codify the prenasalization of CV clusters, he does not do so for the first consonant of CVC clusters either. Rather, he silently lumps its potential presence at Step 3 of the Horizontal Base. Likewise, he does not codify the palatalization or labialization of the second consonant, again silently lumping its potential presence at Step 3 of the Horizontal Base. While this is not linguistically sound, his reasoning must have been that in Step 1 he was only interested in changes around the vowel of each $\mathrm{CV}(\mathrm{C})$ structure.

Step 2 could be said to be the signpost for the word class or part of speech; the two major categories being VERBE to introduce base verbs, and SUBST. to introduce base nouns. Verbs and nouns, as well as occasionally other word classes, derived from this are grouped in a section preceded by V.DER. Word forms that cannot be derived from the previous are brought together under VARIA. While pre-grammatical forms are to be found in their own separate part (i.e., Part I) of the dictionary, references to them are, when applicable, signalled at the start of Step 2 with the signpost PREGR. Step 2 is repeated for each (relevant) Code from Step 1, in the order just described.

Step 3 is used with two of the signposts from Step 2: SUBST. and V.DER. At SUBST. the plural prefix of the nouns that follow is shown, as if to say that a collection (hence the plural) of nouns from that gender is announced. ${ }^{8}$ Table 3 lists the labels used for the nouns at Step 3, together with their actual singular and plural prefixes as well as the gender numbers in use today.

Table 3: SUBST. 'noun prefixes' used at Step 3 of the Horizontal Base in Polis's Lexique

\begin{tabular}{lll}
\hline SUBST. & Singular / Plural prefixes & Modern gender numbers \\
\hline ba & mu-, mw-, N- / ba- & $1 / 2$ \\
bi & ki-, ø- / bi- & $7 / 8$ \\
bu & bu- & 14 \\
ma & di-, ø- / ma- & $5 / 6$ \\
mi & mu-, mw-, N- / mi-, mw-, & $3 / 4$ \\
& N- & \\
tu & lu- / tu- & $11 / 13$ \\
zi & $\mathrm{N}-/$ N-
\end{tabular}


http://lexikos.journals.ac.za

The Lexique kikongo-français by Charles Polis (1938)

\begin{tabular}{llll} 
& & & \\
\hline$(\mathrm{ku})$ & $\mathrm{ku}-/$ ma- & $15 / 6$ & (Part II, pp. 369, 381, 475, 478) \\
$\mathrm{ga}$ & $\mathrm{ga-}$ & 16 & (Part II, p. 314) \\
$(\mathrm{ku})$ & $\mathrm{ku}-$ & 17 & (Part II, p. 318, 636) \\
$g u$ & $g u^{-}$ & $17 ?$ & (Part II, p. 314) \\
$m u$ & $m u^{-}$ & 18 & ? \\
$\mathrm{fi}$ & $\mathrm{fi}-$ & 19 & (Part II, p. 47) \\
\hline
\end{tabular}

The abbreviation $\mathrm{N}$ at gender $9 / 10$ stands for the non-syllabic homorganic nasal, to contrast it with the syllabic homorganic nasal $\mathrm{N}$ found in classes 1, 3 and $4 .{ }^{9}$ Orthographically, Polis differentiates the syllabic from the non-syllabic nasals by doubling the nasal when it is syllabic, for instance: nnkeento/bakeento 'woman/-en' (1/2) and mmvu 'year(s)' (3/4) vs. nzo 'house(s)' (9/10) and mbwa 'dog(s)' (9/10). With only the plain characters of a typewriter at hand, Polis came up with a wonderfully simple and straightforward way to draw attention to the difference between syllabic and non-syllabic nasals, which is most definitely an improvement over the earlier works by Butaye $(1909,1910)$, who doesn't mark the difference and only uses simple nasals. ${ }^{10}$ Further note that Polis orders the nouns in Step 3 using his usual alphabetical ordering, as seen in (11) and (12): B, M, T, Z - followed by the addition of the relevant vowels for each of these. ${ }^{11}$ Only those labels for which nouns are eventually presented are listed. The noun classes under the dashed line in Table 3 are infrequently used; the few instances we noted are referenced.

At V.DER. a large battery of labels for 'extensions' (real or perceived, and the eventual words themselves often with further extensions) is used. The main and more productive ones are shown in Table 4. This table lists the labels in the ordering used by Polis (from left to right, and within each column from top to bottom), which again follows the orderings (11) and (12). Of course no single V.DER. signpost has all these labels; what is not relevant is simply skipped. ${ }^{12}$

Table 4: V.DER. 'extensions' used at Step 3 of the Horizontal Base in Polis's Lexique

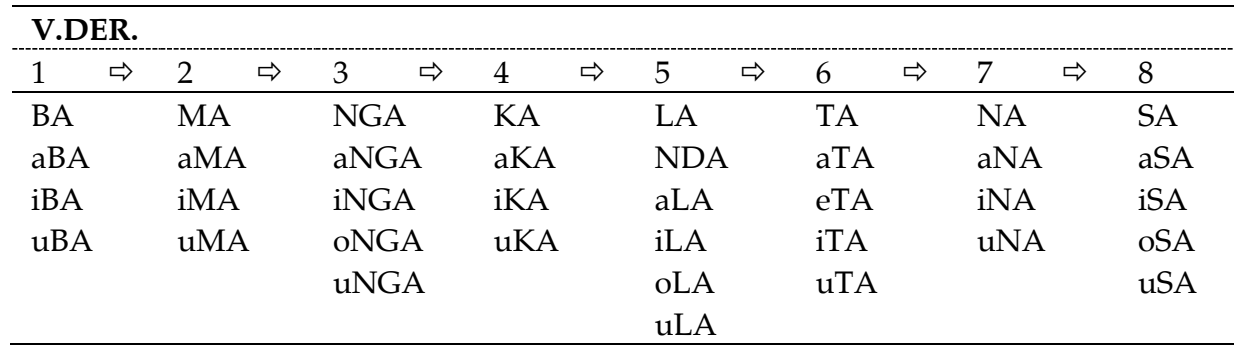

In the case of verbs with verbal extensions, Table 4 reveals that these are thus unfortunately not explicitly marked. Implicitly, though, a possible (first) verbal extension may be guessed from the label, such as the rollative (-Vb-) in column 1 , 
the stative (-am-) in column 2, the imperfective (-ang-) in column 3, the impositive (-ik-) and intransitive oppositive (-uk-) in column 4, the agitative (-al-), applicative (-il-) and oppositive (-ul-) in column 5, the contactive (-Vt-) in column 6, the reciprocal (-an-), expressive (-in-) and debilitative (-un-) in column 7 , or finally the ergative (-as-) and causative (-is-) in column $8 .{ }^{13}$

The Horizontal Base in Part I simplifies that seen in Part II: Step 1 is kept, Step 2 is skipped, and for Step 3 only a set of numbers is used to represent extensions to the base clusters, namely 1 for -B-, 2 for -M-, 3 for -NG-, 4 for -K-, 5 for -L-, 6 for $-\mathrm{T}-, 7$ for $-\mathrm{N}-$, and 8 for $-\mathrm{S}-$. This is analogous with the V.DER. extensions which are otherwise used at Step 3 (compare with Table 4), with this difference that combinations of extensions are marked explicitly here, resulting in for instance 15 for -abala, 38 for -engese, 77 for -anana, 546 for -olokoto, etc.

At last we are now in a position to combine the Vertical Base and the Horizontal Base, as illustrated with a number of selected examples in Table 5, to arrive at 'real words' in Polis's work.

Table 5: Combining the Vertical Base and the Horizontal Base in Polis's Lexique: Selected examples for each of the Codes used

\begin{tabular}{|c|c|c|}
\hline Codes & With CV clusters & With CVC clusters \\
\hline \multirow[t]{3}{*}{$\mathrm{Y}$} & $\begin{array}{l}\text { Da }+ \text { Y, SUBST., bi > kindya, kidya } \\
\text { (Part II, p. 82) }\end{array}$ & $\begin{array}{l}\text { NeM + Y, V.DER., iTA > nyeemita } \\
\text { (Part II, p. 498) }\end{array}$ \\
\hline & - & $\begin{array}{l}\text { ZuG + YI, V.DER., aLA > zyungalakana } \\
\text { (Part II, p. 547) }\end{array}$ \\
\hline & - & $\begin{array}{l}\text { FoT + YII, VARIA > fyote } \\
\text { (Part II, p. 282) }\end{array}$ \\
\hline \multirow[t]{4}{*}{ W } & $\begin{array}{l}\text { Fa }+ \text { W, SUBST., zi }>m f w a \\
(\text { Part II, p. } 45)\end{array}$ & $\begin{array}{l}\text { SaM + W, V.DER., uNA > kiswaamunu } \\
\text { (Part II, p. 538) }\end{array}$ \\
\hline & - & $\begin{array}{l}\text { TeG + WI, SUBST., bi > tweengi } \\
\text { (Part II, p. } 463 \text { ) }\end{array}$ \\
\hline & - & $\begin{array}{l}\text { SeT + WII, V.DER., aMA > sweetama } \\
\text { (Part II, p. 591) }\end{array}$ \\
\hline & & $\begin{array}{l}\text { Set }+ \text { WII, } 4>\text { sweetika } \\
(\text { Part I, p. 59) }\end{array}$ \\
\hline \multirow[t]{3}{*}{$\mathrm{O}$} & $\begin{array}{l}\text { Ka }+ \text { O, Varia }>a k a \\
(\text { Part II, p. 63) }\end{array}$ & $\begin{array}{l}\text { SiN + O, SUBST., bi > kisina } \\
\text { (Part II, p. 595) }\end{array}$ \\
\hline & - & $\begin{array}{l}\text { KoD \& KoL + OI, V.DER., iSA > koondisa } \\
\text { (Part II, p. } 363 \text { ) }\end{array}$ \\
\hline & - & $\begin{array}{l}\text { VuT + OII, SUBST., zi > mvutu } \\
\text { (Part II,p. 272) }\end{array}$ \\
\hline $\mathrm{I}$ & - & $\begin{array}{l}\text { YaG + I, VERBE > yanga } \\
\text { (Part II, p. 609) }\end{array}$ \\
\hline II & - & $\begin{array}{l}\text { YeK + II, V.DER., iKA > yekikila } \\
\text { (Part II, p. 614) }\end{array}$ \\
\hline
\end{tabular}


The words listed in Table 5 are however not the only words generated by each respective Vertical Base + Horizontal Base. For instance, ZuG + YI, V.DER., aLA also leads to zyungalakasa (i.o.w., the ergative replaced the reciprocal as the final verbal extension), or KoD \& KoL + OI, V.DER., iSA also leads to kondisanga (where the imperfective was added), or YaG + I, VERBE also leads to iyanga (now with a preceding reflexive), or even YeK + II, V.DER., iKA which also leads to simply yekika (where the applicative was dropped). Therefore, where and how are these different 'words' (i.e., the ones in italics in Table 5) now listed in Polis's work? This is the topic of the next section, as we move to the microstructure.

\subsection{The microstructure of the Lexique}

\subsubsection{The microstructure in Part II}

Our discussion will be revolving around a single CVC cluster, namely the ZaZ cluster (Part II, pp. 127-128), reproduced in Addendum 2. This one CVC cluster runs over nearly two pages, and is obviously an example of one of the longer ones (recall there are $1592 \mathrm{CV}(\mathrm{C})$ clusters, on 716 pages). It was chosen as it is representative of a large number of the features of Polis's work. The full ZaZ cluster may be synthetized as shown in Table 6. Getting to the ZaZ cluster has been explained in Section 3.1.2 (on the Vertical Base), while the first three columns seen in Addendum 2 as well as Table 6 were covered in Section 3.1.3 (on the Horizontal Base). All of this may be considered as a multi-pronged approach that leads directly into the 48 'items' listed in column 4 of Table 6 .

The items are often, but by no means always, the first 'word' of the microstructure. If not, in all but a few cases the formulaic macrostructure (i.e., the codified Vertical Base + Horizontal Base) enables one to pinpoint the item that is the focus of the lexicographical description. Items that are not at the start of their entry in the microstructure include the verb zanzalaanga at $\mathbf{Z a Z}+\mathrm{OI}$, V.DER., LA for which only an example sentence is provided: "nkasa iye zanzalaanga mu nitu yakulu, le poison se répand à travers le corps" [the poison is spreading through the body], or the noun mazaaza at ZaZ + OII, SUBST., ma which is used in the example: "ndiinga ifwiidi mazaaza, voix rauque (on perçoit des tremblements $z a z a z a)$ " [the voice is hoarse (one notices a trembling $z a z a z a)$ ]. The item nzanzumune is even imbedded in a children's song. Also, some items are actually collocations: nzanza madyaadi, 'carton' di nzanza, kweenda nzanzuba, nzanzala koondi(i), zaaza tiiya, zaza uzaza, zaaza ki bampaangi, nzazi nzazi, and mmbanda $\underline{n z a z i}$. The items are moreover not always presented in their canonical form, given that some remain unlemmatised, as at ZaZ + OI, V.DER., MA where one of the entries is the following example sentence: "ikizanzumuna, je m'explique, m'excuse, me défends" [I explain/excuse/defend myself] rather than the reflexive verb-kizanzumuna as item. 
Table 6: Synthesis (and translation) of the ZaZ cluster in Polis's Lexique

\begin{tabular}{|c|c|c|c|c|c|c|c|c|}
\hline \multirow{2}{*}{$\begin{array}{l}\text { Code } \\
\text { YI }\end{array}$} & POS & \multicolumn{2}{|c|}{ Affix Item } & \multirow{2}{*}{$\begin{array}{l}\text { Grammar ... } \\
-\end{array}$} & \multirow{2}{*}{$\frac{\text { NTD }}{-}$} & \multirow{2}{*}{$\begin{array}{l}\text { Meaning } \\
-\end{array}$} & \multicolumn{2}{|c|}{ COL EG } \\
\hline & PREGR. & & cf. previous & & & & - & - \\
\hline & VERBE & & zyaanza & $\begin{array}{c}>\text { zyanzidi } \mathcal{E} \\
\text { zyeenze }\end{array}$ & $\checkmark$ & to get out quickly & 4 & - \\
\hline & V.DER. & MA & & -zyanzamene & - & be lash; be straight & - & 3 \\
\hline & & KA & zyanzika & $\begin{array}{l}\text { caus. of } \\
\text { zyanzama }\end{array}$ & - & - & - & - \\
\hline \multirow[t]{5}{*}{ YII } & PREGR. & & cf. previous & - & - & - & - & - \\
\hline & VERBE & & $\ldots$ & - & - & - & - & - \\
\hline & SUBST. & $\mathrm{mi}$ & nnzyaasi & - & - & a straight thing & - & 3 \\
\hline & & & nnzyaasi & - & - & name of a bush liana & - & - \\
\hline & V.DER. & & zyaazama & - & 一 & $\begin{array}{l}\text { be long, be stretched } \\
\text { out (of snake, ...) }\end{array}$ & - & - \\
\hline WI & $\ldots$ & & $\cdots$ & - & - & - & - & - \\
\hline \multirow[t]{4}{*}{ WII } & PREGR. & & cf. previous & - & - & - & - & - \\
\hline & VERBE & & $\ldots$ & - & - & - & - & - \\
\hline & SUBST. & bi & zzuaazu & - & - & fly whisk & - & - \\
\hline & & $\mathrm{zi}$ & nzuaazu & - & - & $\begin{array}{l}\text { whipping; noise that } \\
\text { sounds like zua }\end{array}$ & 3 & - \\
\hline \multirow[t]{17}{*}{$\mathrm{OI}$} & PREGR. & & cf. previous & - & - & - & - & - \\
\hline & VERBE & & zaanza & ant. batalala & - & $\begin{array}{l}\text { to be up front, to be } \\
\text { rising, to be in line }\end{array}$ & - & 3 \\
\hline & SUBST. & bi & kinzanza & - & - & tin, tin can & 2 & - \\
\hline & & ma & $z a n z a$ & cf. nza baantu & - & large quantity & 4 & - \\
\hline & & & manzanza & - & - & $\begin{array}{l}\text { fetish nkita which had } \\
\text { its kimpasi }\end{array}$ & - & - \\
\hline & & & $\operatorname{dinzanza}$ & cf. nzaanza & - & small boat & - & - \\
\hline & & $\mathrm{mi}$ & nnzaanza & - & - & bush between streams & - & - \\
\hline & & & nnzaanza & syn. ntaantu & - & $\begin{array}{l}\text { liana or pole serving } \\
\text { as a bridge }\end{array}$ & - & - \\
\hline & & $\mathrm{tu}$ & lunzanza & - & - & $\begin{array}{l}\text { kind of fly very eager } \\
\text { for blood }\end{array}$ & - & - \\
\hline & & & lunzaanza & - & - & wide-openness & 1 & - \\
\hline & & $\mathrm{zi}$ & nzanza & - & - & arrow & - & 2 \\
\hline & & & $\begin{array}{l}\text { nzanza } \\
\quad \text { madyaadi }\end{array}$ & - & - & $\begin{array}{l}\text { edible rat, which } \\
\text { roams the madyaadi } \\
\text { grass }\end{array}$ & - & - \\
\hline & & & nzaanza & - & - & whale boat, steel boat & - & - \\
\hline & & & $\begin{array}{l}\text { 'carton' di } \\
\text { nzanza }\end{array}$ & - & - & $\begin{array}{l}\text { tin sheet used as the } \\
\text { back of a cupboard }\end{array}$ & - & - \\
\hline & & & nzaanza & - & - & line & - & 1 \\
\hline & V.DER. & BA & $z a a n z a b a$ & - & - & $\begin{array}{l}\text { to crawl (of snakes, } \\
\text { insects, ...) }\end{array}$ & - & - \\
\hline & & & $n z a n z a b a(i)$ & - & - & $\begin{array}{l}\text { large insect which } \\
\text { climbs in trees }\end{array}$ & - & - \\
\hline
\end{tabular}




\begin{tabular}{|c|c|c|c|c|c|c|c|c|}
\hline \multicolumn{2}{|c|}{ Code POS } & \multirow{2}{*}{\multicolumn{2}{|c|}{$\begin{array}{l}\text { Affix Item } \\
\text { kinzanzabala }\end{array}$}} & \multirow{2}{*}{$\begin{array}{l}\text { Grammar ... } \\
-\end{array}$} & \multicolumn{2}{|c|}{ NTD Meaning } & \multicolumn{2}{|c|}{ COL EG } \\
\hline & & & & & $\checkmark$ & $\begin{array}{l}\text { a young boy, a small } \\
\text { girl }\end{array}$ & - & - \\
\hline & & & $n n z a n z u b a(u)$ & - & - & $\begin{array}{l}\text { winged insect, comes } \\
\text { out of the ground }\end{array}$ & - & 一 \\
\hline & & & $\begin{array}{l}\text { kweenda } \\
\quad \text { nzanzuba }\end{array}$ & - & $\checkmark$ & to hurry & 一 & 一 \\
\hline & & MA & zaanzama & - & - & $\begin{array}{l}\text { be in line, to make a } \\
\text { line }\end{array}$ & - & 3 \\
\hline & & & zanzumuna & - & 一 & $\begin{array}{l}\text { to do a little and then } \\
\text { move on }\end{array}$ & - & 1 \\
\hline & & & $\begin{array}{c}-k i z a n z u- \\
\text { muna }\end{array}$ & - & - & $\begin{array}{l}\text { to explain/excuse/ } \\
\text { defend oneself }\end{array}$ & - & - \\
\hline & & & & $\begin{array}{l}- \text { zaanzu- } \\
\text { mukini }\end{array}$ & - & $\begin{array}{l}\text { be having pins and } \\
\text { needles }\end{array}$ & 1 & - \\
\hline & & & $\begin{array}{l}\text { zanzumuni } \\
\quad \ldots ?\end{array}$ & - & - & $\begin{array}{l}\text { to oscillate, to go } \\
\text { quickly }\end{array}$ & - & - \\
\hline & & & nzanzumune & - & - & $\begin{array}{c}\text { (maybe just used for } \\
\text { the sound effect?) }\end{array}$ & 一 & - \\
\hline & & NGA & nzanzaanga & $\begin{array}{l}\text { the 1st 'a' H, } \\
\text { the 2nd L }\end{array}$ & 一 & $\begin{array}{l}\text { forest tree whose } \\
\text { wood is not very } \\
\text { strong }\end{array}$ & 一 & - \\
\hline & & KA & zaanzika & $\begin{array}{l}\text { caus. of } \\
\text { zaanzama }\end{array}$ & - & - & - & - \\
\hline & & LA & zaanzala & - & 一 & to crawl; ...? & 一 & - \\
\hline & & & bizaanzala & - & 一 & $\begin{array}{l}\text { that which crawls (i.e., } \\
\text { insects, ants) }\end{array}$ & 一 & 一 \\
\hline & & & $\begin{array}{l}\text { nzanzala } \\
\quad \text { koondi(i) }\end{array}$ & - & 一 & spider web & - & - \\
\hline & & & zanzalaanga & - & - & to spread & - & - \\
\hline \multirow[t]{12}{*}{ OII } & \multirow{2}{*}{\multicolumn{2}{|c|}{$\begin{array}{l}\text { PREGR. } \\
\text { VERBE. }\end{array}$}} & cf. previous & - & - & - & 一 & 一 \\
\hline & & & $z a a z a$ & > zeeze & $\checkmark$ & be very ripe & 一 & - \\
\hline & & & zaaza tiiya & syn. zaasa? & 一 & $\begin{array}{l}\text { to light a line of fire } \\
\text { (along the forest) }\end{array}$ & 一 & - \\
\hline & & & zaza uzaza & - & - & be talkative & 一 & 一 \\
\hline & \multirow[t]{6}{*}{ SUBST. } & bi & $\begin{array}{l}\text { zaaza ki } \\
\quad \text { bampaangi }\end{array}$ & - & 一 & $\begin{array}{r}\text { instinct to imitate, fear } \\
\text { of other's judgement }\end{array}$ & 一 & 一 \\
\hline & & ma & mazaaza & $\begin{array}{l}+ \text { trembling } \\
\text { voice }\end{array}$ & 一 & hoarse & 一 & 一 \\
\hline & & $\mathrm{mi}$ & $n n z a z i$ & - & - & $\begin{array}{l}\text { a strip of bush being } \\
\text { farmed }\end{array}$ & 一 & 一 \\
\hline & & & nzazi nzazi & - & - & along & 一 & - \\
\hline & & $\mathrm{zi}$ & $n z a z i$ & $\begin{array}{l}\text { syn. } N i \\
\text { Kongo }\end{array}$ & 一 & lightning & 一 & 一 \\
\hline & & & $\begin{array}{c}\text { mmbanda } \\
n z a z i\end{array}$ & - & - & kind of plant & 一 & - \\
\hline & \multirow[t]{2}{*}{ V.DER. } & LA & zaazila & - & 一 & to tremble & 2 & - \\
\hline & & & nzaazila & - & 一 & trembling, vibration & - & 1 \\
\hline
\end{tabular}


Following the signpost VERBE the base verbs are shown, here zyaanza at YI, $z a a n z a$ at OI, and zaaza at OII. Even though one could be led to assume that everything that follows is related semantically to each of these starting points, this is of course not the case. While base verbs are often accompanied by their perfect forms (as seen at zyaanza > zyanzidi $\mathcal{E}$ zyeenze and zaaza > zeeze), perfects of verbs with verbal extensions may be items in themselves (such as -zyanzamene and -zaanzumukini), and are thus included without a mention of their more canonical form.

Although Polis is not explicit in this regard, and certainly not systematic, he does include information on grammar (perfects, verbal extensions, etc.), pronunciation (especially on tone), lexical relations (synonyms, antonyms, etc.), various cross-references, and in other CVC clusters also labels and even usage notes. This type of information has been grouped in column 5 of Table 6 .

At times, and in addition to a translation equivalent, Polis also provides a paraphrase in the language itself, information which typically precedes the translation equivalent proper. In Table 6 the presence of such information is indicated with a tick mark $(\checkmark)$ in the column headed by NTD (for Kintandu).

The most important information contained in any dictionary is of course the meaning; in a bilingual dictionary consequently the translation equivalents. Here Polis does rather well although one often needs to 'derive' the generic meaning from a series of collocations (COL) or example sentences (EG). The number of additional collocations and example sentences used to achieve this is indicated in the last two columns of Table 6: these come over and above the items which are collocations or examples in themselves.

\subsubsection{The microstructure in Part I}

By and large, the microstructure seen in Part I mimics that of Part II, albeit that it is on the whole simpler. This has to do with the nature of what Polis terms pre-grammatical forms. These turn out to be mostly ideophones (Doke 1935: 118), a decidedly elusive word category to characterise semantically as well as lexicographically (see De Schryver 2009). Various specific sounds and exclamations are also covered in part I, as well as the occasional infrequent word class. A sample page is shown in Addendum 3, with the synthesis presented in Table 7.

Ideophones, while an important word category of Bantu languages, are often overlooked in dictionaries. Polis's lists are a true treasure trove. Especially interesting are his and his team's attempts to derive other word classes from them, such as their suggestions that nùu /núu gave rise to the verb nuuka, or that nyau gave rise to the verb nyaanga. While the paraphrase and folk etymology seen at nnniii(w)iiiii vacillates between being intriguing and funny, the information does give extra insight into the compilation approach: even casual interlocutors (no doubt grabbed from their bicycles while on the way to the market) provided input on the words' uses, meanings and etymologies. 
Table 7: Synthesis (and translation) of a pre-grammatical page (Part I, p. 24) from Polis's Lexique

\begin{tabular}{|c|c|c|c|c|c|c|c|}
\hline Vertical & Horizontal & Item & Meaning & Grammar ... & NTD & $\mathrm{COL}$ & EG \\
\hline Base & Base & & & & & & \\
\hline $\mathrm{Ne}$ & $\mathrm{Y}$ & nye & of emptiness & - & - & - & 2 \\
\hline & & nnye & of crushing & - & - & - & 1 \\
\hline & & nyee & of piercing pain & - & - & - & 2 \\
\hline & & nyeee & $\begin{array}{l}\text { cry of the cicada } \\
\text { mungyeenga }\end{array}$ & - & - & - & 一 \\
\hline & & nye nye & $\begin{array}{l}\text { the crying of small } \\
\text { children }\end{array}$ & - & - & - & - \\
\hline & W & nwe & of pinching & - & - & - & - \\
\hline & & пие пие & of small movements & - & - & - & 1 \\
\hline & & nuе nue & sound of muffled fart & - & - & - & - \\
\hline & $\mathrm{O}$ & ne & of solitude & - & - & - & - \\
\hline $\mathrm{Ni}$ & W & $n w i$ & of rapidness & - & - & - & - \\
\hline & & $n w i$ & sound of muffled fart & - & - & - & - \\
\hline & & & (May.) of sweetness & - & - & - & 一 \\
\hline & $\mathrm{O}$ & ni ni ni & $\begin{array}{l}\text { cry of small children } \\
\text { when they see a } \\
\text { parent arrive }\end{array}$ & - & - & - & 一 \\
\hline & & $n n i$ & $\begin{array}{l}\text { buzzing (of flies, } \\
\text { wasps, ...) }\end{array}$ & - & - & - & 一 \\
\hline & & nnniii(w)ii & $\begin{array}{l}\text { sound of a bee, with } \\
\text { (w) a small change } \\
\text { in sound correspon- } \\
\text { ding to the moment } \\
\text { the bee stops its } \\
\text { wings to sting }\end{array}$ & $\begin{array}{l}\text { (w) has } \\
\text { become } u \text { in } \\
\text { the word } \\
\text { nyuki 'bee' } \\
\text { (according to } \\
\text { a casual } \\
\text { interlocutor) }\end{array}$ & - & - & 一 \\
\hline No & YW & $\ldots$ & - & - & - & - & - \\
\hline & $\mathrm{O}$ & nno, no & of dripping & - & - & - & 1 \\
\hline $\mathrm{Nu}$ & Y & nyu & $\begin{array}{l}\text { (May.) of piercing } \\
\text { pain }\end{array}$ & - & $\checkmark$ & - & - \\
\hline & & nuu & $\begin{array}{l}\text { of bad smell (with } \\
\text { grimace) }\end{array}$ & $\begin{array}{l}\text { L tone; > v. } \\
\text { nuuka smell }\end{array}$ & - & - & 一 \\
\hline & & nuи & of good smell & $\begin{array}{l}\text { H tone; > v. } \\
\text { nuuka smell }\end{array}$ & - & - & 一 \\
\hline Nau & & nyau & mewing of a cat & > v. nyaanga & - & - & - \\
\hline Nan & $\mathrm{Y}$ & nyana & of tiptoeing & - & - & - & 1 \\
\hline & & nya nya & $\begin{array}{l}\text { exclamation of sur- } \\
\text { prise, of disapproval }\end{array}$ & - & - & - & - \\
\hline & & nyanika & of twinkling & - & - & - & 1 \\
\hline & W & nuana & of rapidness & - & - & - & 一 \\
\hline & & nuanuna & of rapidness & - & - & - & 一 \\
\hline & & nanika & of movement & - & - & 1 & 1 \\
\hline
\end{tabular}




\subsection{The mediostructure of the Lexique}

The mediostructure of a dictionary is the system of cross-referencing (Wiegand 1996, Gouws and Prinsloo 1998). A frequent type of cross-reference found in Polis's work is the one from Part II to Part I, linking the main dictionary material to the pre-grammatical forms. As could be seen from Addendum 2 and Table 6, the reference marker used for this is cfr antea [cf. previous]. The reference position is always the same, namely the microstructural slot following the signpost PREGR. in Step 2 of the macrostructure's Horizontal Base, while the reference address remains undefined. However, given the structure of the dictionary the reference address can be said to be implicit. For instance, the external reference addresses for the reference positions of this type in the ZaZ cluster (see Table 6) cross-refer to the corresponding entries in the Zaz cluster, reproduced in Addendum 4 and synthetized in Table 8. ${ }^{14}$

Table 8: Synthesis (and translation) of the pre-grammatical Zaz cluster (Part I, p. 26) in Polis's Lexique

\begin{tabular}{|c|c|c|c|}
\hline $\begin{array}{l}\text { Vertical } \\
\text { Base } \\
\end{array}$ & $\begin{array}{l}\text { Horizontal } \\
\text { Base }\end{array}$ & Item & Meaning \\
\hline \multirow[t]{4}{*}{$\overline{Z a z}$} & YII & $z y a z y a$ & of gushing forth (e.g. blood) \\
\hline & WII & $z w a z w a$ & $\begin{array}{l}\text { alternating hitting sound of a flexible stick } \\
\text { used to cut grass left and right }\end{array}$ \\
\hline & OI & $\begin{array}{l}\text { zanzumuni } \\
\text { zazumuni }\end{array}$ & of rhythm (dance, fast walk) \\
\hline & OII & $z a z a z a$ & of trembling (arrow, lightning, dance, voice) \\
\hline
\end{tabular}

Several other cross-reference markers are found, including $c f r$ / $c f r$; $c f$ / $c f . ; c f r$ supra; cfr Prov. et devinn. / cfr devinn. [for references to proverbs and riddles]; and syn. These typically link items within a single CVC cluster or from different CVC clusters to one another. In addition to such explicit cross-references to items (i.e., full words) within the microstructure, explicit cross-references to specific Steps in a CVC cluster's macrostructure are also found, such as "cfr NGA, KA" at DoK \& LoK + OII, V.DER., uLA (Part II, p. 458).

Lastly, the excerpts (36) to (38) show that the stacking of near-synonyms in Kintandu (seen at (36)) en lieu of a proper translation equivalent should also be considered to be (implicit) cross-references, for which alternatively aussi [also] (as seen in (37)) or simply cfr [cf.] (as seen in (38)) are used. These three items (maanga, mpyaata and ngoombe) cross-refer to one another, but in three different ways:

(36) MaG + OI, SUBST., ma (Part II, p. 228): nkisi maanga, mpyaata, ngoombo; ta maanga ma nkele, faire le jugement du fusil (tirer de près, s'il touche coupable, sinon libre) [do the gun judgement (shoot at close range, when he hits: guilty, if not: free)]; twe teesa keti fimanga, allons consulter (un brin de fétiche) [let's consult 'a bit of fetish']. 
(37) PaT + YII, SUBST., zi (Part II, p. 209): mpyaata, fétiche pour découvrir la cause magique d'une maladie [fetish to discover the magical cause of an illness]. aussi [also] ngoombo, maanga. ...

(38) GoB + OI, SUBST., zi (Part II, p. 295): ... nggoombo mu baabila ina, la boîte-fétiche est en train de trembler (elle indique le coupable) [the fetish box is trembling (it indicates the guilty person)], cfr maanga, mooko, mpyata....

\section{Lexicographical appreciation of Polis's Lexique}

Before Polis's Lexique can be subjected to a true evaluation, a number of additional lexicographical elements must be pointed out and clarified further.

\subsection{On the language and human resources}

We already concluded that the main KLC variety covered is Kintandu, but is it the 'pure' Kintandu? In more than one place in the dictionary's microstructure, one finds example sentences such as the one seen in (39):

(39) BiB + OI, SUBST., zi (Part II, p. 16): kikongo kizole, ki mbiimba, le kikongo second (en opposition à l'ancien, celui des indigènes), celui des écoles, de fabrication étrangère, avec des obscurités [the second Kikongo (in opposition to the historical one, the one of the natives), the one of the schools, of foreign fabrication, with obscurities] ...

As so often with the laudable missionary efforts to codify a language and to reduce it to writing, they were at times either overzealous in their manipulation of the language, or the mother-tongue speakers felt that despite their efforts, the result still sounded stilted. One thus has to keep in mind that the data may not be as 'pure' as one would want them to be.

That said, one must also realise that Polis tried to give as accurate a picture as possible, being open about disagreements between his collaborators, as for instance seen in (40) and (41):

(40) BuB + OII, V.DER., TA (Part II, p. 25): ... muuntu utabuubuta mu nzo, qqun est en train de tâtonner dans la maison (contesté par d'autres qui disent, baabita) [someone is busy groping along in the house (contested by others who say baabita (rather than buubuta))] ...

(41) KuD \& K3uL + OI, V.DER., uBA (Part II, p. 368): nzau mu kwisa kunduba ina, l'éléphant s'amène de son pas pesant, majestueux [the elephant arrives in his heavy, majestic step]; mwaana mu k. ina, l'enfant rampe à 4 pattes (sens contesté, il faudrait kuluba) [the child crawls on all fours (contested meaning, one would need kuluba (rather than kunduba))] ...

Polis also went to great length specifying where he recorded the material, whether or not in Mbata for instance, as in (42) vs. (43), or showing the differ- 
ences between KLC varieties, especially the differences between Kintandu and Kimbata, as in (44) where the plural of kutu 'ear' is makutu in Kintandu but matu in Kimbata:

(42) TaD \& TaL + OII, V.DER., iSA (Part II, p. 481): quelle direction prenez-vous? [which direction do you take?]; - ntadisa mpuumbu, la direction du Pool, le Nord [the direction of the Pool, the North]; - $\underline{n t}$. Koongo, celle de S. Salvador, le Sud [the direction of S. Salvador, the South]; - $\underline{n t}$. Mbaamba, celle de Mbaamba, l'Est [the direction of Mbamba, the East]; - $\underline{n t}$. Nsuundi, l'Ouest (orientation des Bambata) [the direction of the Nsundi, the West (orientation of the Bambata)] ...

(43) LuL + O, SUBST., tu (Part II, p. 103): ... Luula, le pays des Baluula (Luula Lumeene); on connait ici (\& à Mbata) Luula lu Mpese, et Luula lu Ntari (dans la région de Thysville) [the country of the Baluula (Luula Lumeene); here we know (\& at Mbata) Luula lu Mpese and Luula lu Ntari (in the region of Thysville)].

(44) KuT + OII, SUBST., (ku) (Part II, p. 381): kutu, plur makutu; MB matu; oreille [ear] ...

\subsection{On grammar (comment on form)}

The microstructure of most dictionary entries may be divided into a comment on form and a comment on semantics (Hausmann and Wiegand 1989: 353-357), directed at the items which are the focus of the lexicographical description. The comment on form in Polis's manuscript mainly deals with pronunciation, morphology and additional word-class information.

In our manuscript, pronunciation information typically concerns tone, and could for instance already be seen for the noun nzanzaanga in Table 6 (at $\mathrm{ZaZ}+$ OI, V.DER., NGA), or for the ideophones nuu in Table 7 (at $\mathbf{N u}+\mathbf{Y}$ ). Another example is shown in (45):

(45) Bok + OII (Part I, p. 31): ... nwa uboka (o, ton très bas), la bouche gronde: bruit de l'eau dans la bouche [ $(0$, very low tone $)$, the mouth roars: sound of water in the mouth] ...

Examples of morphological information could also already be seen in Table 6 , in the column headed by 'Grammar ...', where the perfect forms are listed (following '>'), or where causatives are explicitly mentioned (following 'caus. of ). Another example is shown in (46):

(46) PuP + OII, V.DER., KA (Part II, p. 32): ... pupuka, passif de pupula [passive of pupula]

While the main word classes are taken care of at Step 2 of the Horizontal Base, less-frequent word classes are mentioned in the microstructure every now and then, especially following the signpost VARIA. These word classes include: 'adverbe' [adverb], 'adjectif' [adjective], 'pronom personnel / pron. pers.' [personal pronoun], 'pronom interrogatif / pron. interrog.' [interrogative pronoun], 'pronom 
relatif' [relative pronoun], 'pronom démonstratif / pron. dém.' [demonstrative pronoun], 'préposition / prépos. / prép.' [preposition], 'possessif / poss.' [possessive], 'conjonction / conj.' [conjunction], 'locatif [locative], 'particule honorifique' [honorific particle], etc., as well as 'verbe / v.' [verb] and 'auxiliaire' [auxiliary]. Examples are shown in (47) and (48):

(47) Na + O, VARIA (Part II, p. 120): ... na conjonction et prépos. [conjunction and preposition]; bu kikala na ntaangu masiinsa, quand il était environ midi [when it was about midday], na bumbuta tala ye mana, depuis que mes parents m'ont engendré [since my parents begot me], na tee ye kuna nsoongi, tout le long jusqu'au bout [all the way until the end]

(48) NeN + O, VARIA (Part II, p. 124): ... neene, adjectif; grand (dans tous les sens) [adjective; big (in all senses)]

The abbreviation ' $v$.' is mostly found in Part $\mathrm{I}$, where verbs derived from the pre-grammatical forms are listed, as seen in (49). These verbs are not normally repeated in Part II, though (50) shows an exception:

(49) Ful + OII (Part I, p. 39): fulu, remplissement [of filling up]; v. fulusa, fulwasa, fuluka

(50) FuD \& FuL + OII, V.DER., uKA (Part II, p. 277): fuluka, plénitude [fullness (i.e., be full)]; nzo ifulukidi na ndyaa, la maison était pleine [the house was full]; - baantu baf. ye kyeese, les gens étaient remplis de joie [the people were full of joy] ...

\subsection{On meaning (comment on semantics) and etymology}

The dictionary's semantics is actually not as undeveloped as the flat microstructure tends to suggest. While it is for instance true that the numbering of senses is rare, an interesting exception is found in Part II, p. 83 "disasana: 1) se donner mutuellement de la nourriture. 2) se manger l'un l'autre" [1) to give one another food; 2) to eat each other]. In Part II, pp. 106-107, up to seven uses/ senses are even listed (and numbered as such) for $t a$.

Polis also often tries to move from core meanings to peripheral ones when ordering his microstructural material. A small selection of short examples includes: "nzeefo vwamvala, barbe touffue, d'où poilu, velu" [bushy beard, hence hairy] (Part I, p. 10), "nua swe swe, boire en aspirant, d'où prégustation" [drink while inhaling, hence pre-tasting] (Part I, p. 29), " $\underline{m m f u}$, un trépassé, d'où revenant, spectre" [a deceased, hence ghost] (Part II, p. 47), "lungungu, roue, d'où bicyclette" [wheel, hence bicycle] (Part II, p. 60), etc.

In order to support the meanings, the French translation equivalents are at times complemented by Dutch equivalents, such as "flauwkens gaan" [to stroll] (Part II, p. 13), "gaarne groot" [be pretentious] (Part II, p. 32), "reus van'ne mensch" [tall, strong man] (Part II, p. 40), "hij loopt op eiren" [he walks very carefully] (Part II, p. 64), "mond vol tanden" [not know what to say] (Part II, p. 117), "stoefferken" [a pocket square] (Part II, p. 165), or "hij kent den hoofdman" 
[he recognises the authority of the chief] (Part II, p. 632). ${ }^{15}$

Loanwords are labelled. For Portuguese with 'du portugais', for instance: dimpa $<$ pão [bread] (Part II, p. 26), papelo < papel [paper] (Part II, p. 28 bis), or ndoona < dona [lady] (Part II, p. 488); and for French with 'du français', for instance: $\underline{\text { buni }}<$ bonnet [bonnet, hat] (Part II, p. 215), moti $<$ mont [mountain] (Part II, p. 236), or ntoma < automobile [car] (Part II, p. 437).

There are also over 50 instances of the label 'vieux mot' [old word], found at items such as: "mmpu, nom récent du chapeau, couvre-chef; vieux mot mmpeewo" [recent word for hat, headgear; old word mmpeewo] (Part II, p. 27), "kimpuumpu, vieux mot pour kitaansi machette" [old word for kitaansi machete] (Part II, p. 31), or "mmbangi, témoin; le vieux mot est kyeesi" [witness; the old word is kyeesi] (Part II, p. 154). References to lexical material that goes back to the 19th century are especially valuable in this regard, as contrary to the Southern and Western KLC varieties (for which lexical material exists that dates from the mid-17th century, respectively late-18th century, cf. Bostoen and De Schryver (2015)), there are no pre-20th-century sources for the Eastern KLC varieties. Glimpses such as those seen in (51) to (53) are thus highly welcome:

(51) BoB + OII, V.DER., LA (, zi) (Part II, p. 19): ... mboobila, petite torsade de perles d'il y a 40 ans [small spiral-shaped pearl necklace from 40 years ago] ...

(52) Se + Y, VERBE (Part II, p. 135): ... sye nge! vieille formule de salut (d'il y a plus de 75 ans) [old greeting formula (from over 75 years ago)]

(53) NaB + YI, SUBST., bi (Part II, p. 496): kinyaambi kimana osi, une épidémie meurtrière d'il y a plus ou moins 100 ans [a fatal epidemic from roughly 100 years ago]; = kibwaaka; nitu zibweke; le corps devenait (pâle) [the body turned 'pale']; cf nyaangi; ngaambu. - le fétiche causant cette maladie [the fetish causing this sickness]

\subsection{On usage (in the extended microstructure) and labels}

Quite a number of items are labelled for register, using mostly 'péjoratif [pejorative] vs. 'terme honnête' [decent term], as seen in (54) and (55):

(54) PeK + OII, VERBE (Part II, p. 175): peka; courir de tous côtés, à généralement sens péjoratif de courir les femmes [run in all directions, generally has the pejorative meaning of chasing women]

(55) TaK + OII, SUBST., ma (Part II, p. 467): ... taku, fesse [arse]; grossier [rude] terme honnête [decent term], kito, ou [or] sina di kuulu ...

Recurrent text boxes are hard to draw on a typewriter, but had the manuscript under consideration been professionally set, the contents of the various Usage Notes would have been a prime candidate to feature in such text boxes. According to Gouws and Prinsloo (2010) text boxes are a device employed in an extended microstructure: 
Instead of a compulsory and consistently applied homogeneous article structure the lexicographer has the liberty to opt for a less rigid heterogeneous article structure in which the compulsory microstructure, the default version of the specific dictionary, can be supplemented by items representing an extended microstructure. [...] One lexicographic device frequently employed in the presentation of data [is] the lexicographic text box [for which the] default presentation seems to be as article-internal microstructural entries within a typical relation of lemmatic addressing. (Gouws and Prinsloo 2010: 501)

In Polis's work such lexicographic devices are introduced by the label 'Nota:' [Note:], and can be directed at both the comment on form, as in (56), or the comment on semantics, as in (57):

(56) BoB + OI, VERBE (Part II, p. 17): ... boomba muuntu mu maambu, engager qqun à son insu dans une affaire [draw someone into an affair without their knowing], kotisa mu maambu, bu kena mu maambu ko, le faire entrer dans l'affaire alors qu'il n'y est pour rien [make him join the affair while he has nothing to do with it].

(Nota: boomba ne prend pas deux régimes) [(Note: $\underline{\text { boomba does not take two }}$ concords)]

(57) TuM + SUBST., zi (Part II, p. 437): ... ntumu iyisidi, une (invitation) est arrivée [an 'invitation' has arrived], kindaanda [(i.e., a message)].

Nota: le concept d'invitation (incluant liberté) n'est pas de mise ici, il s'agit d'annonce d'événements qu'on doit annoncer et pour lesquels on doit répondre à l'annonce par une visite [Note: the concept of an invitation (without obligations) is out of place here; this refers to the announcement of events which have to be announced and to which one must reply by means of a visit]

Observe that the Note presented at (5) above has, in contrast to (56) and (57), a synoptic assignment, as it is directed at all entries where the label 'MB.g' is used. While the single assignment at (56) and (57) employs immediate addressing, the synoptic assignment seen at (5) does not employ any immediate addressing, only distant addressing.

\subsection{On culture and history}

As is the case for any reference work that seeks to present the lexicon of a language which is foreign to the reader, culture-specific information stands out, both with regard to concrete objects, as in (58), and with regard to the speakers' world view, as in (59):

(58) DaZ \& DaS \& LaZ \& LaS + OI, SUBST., mi (Part II, p. 490): nnlaanzi, bout d'étoffe pendu par devant et par derrière; cache-sexe [piece of cloth hung up in front and at the back; sexual-organ cover, 'G-string'] ...

(59) KoK + OII, V.DER., uLA (Part II, p. 78): kiilo ki nnkookolo mi nsusu, le sommeil du temps des chants des coqs, c'est le troisième sommeil, celui du petit matin [that 
part of sleep during the singing of the cocks, this is the third sleep, the one of the early morning]

Other aspects of the culture, while being rather universal, are certainly marked among the Bakongo/Bantandu, as may for instance be deduced from (60) and (61), which both deal with language:

(60) NiM + O, VARIA (Part II, p. 499): goga lunima, ou goga nseka noomba, parler en permutant l'ordre des syllabes, $b a-n g u$ pour $n g u-b a$, langue secrète des enfants [talk in which the order of the syllables is swapped, $b a-n g u$ for $n g u-b a$, secret language of children]

(61) SaL \& SaD + OII, V.DER., iSA (Part II, p. 583): sadisa muuntu, travailler avec qqn., l'aider; faire pour qqn. [work with someone, help him/her; do for someone] (sadila muuntu); - bansadisa mu kunsaansa, ils m'aident à l'élever, le soigner [they help me to raise him/her, to take care of him/her]; - nyiimpi kena, kaansi bafweete kunsadisila mu maambu maakulu, il est bien portant, mais on doit l'aider pour tout; (devinette; le petit enfant) [he is in good health, but needs to be helped for everything; (riddle; (answer:) the small child)] ...

Finally, Polis's manuscript also contains quite a number of snippets comprising historical information, with for instance references to and descriptions of the course of trade networks passing through the region (62), the location of former local markets and their goods (63), as well as explanations of 'indigenous' customs which turn out to be anything but, being merely the result of historical encounters (64):

(62) Fa + W, SUBST., mi (Part II, p. 45): ... ffwa, unene ngutu; le Stanley Pool est très grand; jadis les gens d'ici faisaient la navette entre le Pool (là où est l'emplacement actuel de la CITAS, parait-il) et le port de Mbala (probablement Ambrizette) [the Stanley Pool is very large; in times past the people from here shuttled between the Pool (there where CITAS is currently located, so they say) and the port of Mbala (probably Ambrizette)]

(63) ZeM + O, V.DER., iSA (Part II, p. 536): zeemisa matadi mu kiseengo, fondre du minerai de fer; il y avait un marché de lingots de fonte à Koonso u Ndeele, l'actuel Boko Kifulama, près de Kisantu [to smelt iron ore; there used to be a market of cast-iron ingots at Konso $\mathrm{u}$ Ndeele, the current Boko Kifulama, close to Kisantu]

(64) DaD + OI, SUBST., zi (Part II, p. 87): $\underline{n d a a n d u}$, shake-hands indigène qui se fait en frottant paume contre paume; les ancêtres avaient vu les Blancs à l'Angola et les imitaient avec un peu d'adaptation [indigenous handshake produced by rubbing palm against palm; the ancestors had seen the Whites in Angola and copied them with a bit of adaptation]

In contrast, explicit references to Polis's missionary work are not very frequent, example (65) shows a rare instance:

(65) YiK + II, V.DER., aMA (Part II, p. 615): bakristu mu yikama, les chrétiens augmentent (en nombre) [there are an increasing number of Christians] 


\section{Metalexicographical analysis of Polis's Lexique}

\subsection{On the nature of the macrostructure}

I have argued elsewhere that a dictionary's macrostructure is not merely the list of lemma signs but also necessarily includes information on the word class and morphology of that lemma sign (De Schryver 2013: 1384). This drew harsh criticism from Rufus Gouws:

Dit is 'n standpunt wat teoreties nie steek hou nie. De Schryver verwar hier die makrostruktuur met die vormkommentaar wat 'n funksioneel en posisioneel segmenteerbare komponent van die mikrostruktuur van 'n woordeboekartikel is. [This is a point of view which doesn't make any sense theoretically. Here, De Schryver confuses the macrostructure with the comment on form, which is a segmentable component - both functionally and positionally - of the microstructure of a dictionary article.] (Gouws 2014: 485-486)

So, what is a dictionary's macrostructure then? According to Wiegand and Gouws's most recent definition (their definition has changed a number of times over the past few decades), in Volume 4 of the International Encyclopedia of Lexicography:

The macrostructure of a printed dictionary is that textual structure that presents the ordering of all those elements of the data memories that contribute to the dictionary type specific macrostructural coverage. (Wiegand and Gouws 2013: 78)

Unfortunately, the concept 'data memory/-ies' is not defined anywhere in the International Encyclopedia of Lexicography. Even in the largest lexicographic documentation corpus available to us (De Schryver 2012), it is only found once, namely in the systematic introduction included in Volume 1 of the Dictionary of Lexicography and Dictionary Research:

All lexicographical partial texts of a dictionary with outer access structure and therefore all the lexicographical partial texts in which an informed user can find lexicographical data in a purposeful way, form the data memory of a printed dictionary. If there is only one word list in a dictionary, this word list is identical to the lexicographical data memory. (Wiegand et al. 2010: 147-148)

A definition which avoids the concept of 'data memory/-ies' has also been provided in Volume 4 of the International Encyclopedia of Lexicography:

A new understanding of macrostructure is introduced: It is the structure which is responsible for the order of all elements of a printed dictionary which make a dictionary type-specific contribution to the macrostructural coverage; the cardinality of its structure-carrying set is identical to the extent of the macrostructural coverage with the result that the macrostructure indicates the macrostructural coverage. (Wiegand et al. 2013: 31) 
No doubt, all of this makes perfect sense within Herbert Ernst Wiegand's General Theory of Lexicography (Gouws 2012), but the outright dismissal of my points seems regrettable, especially given that they also admit:

\begin{abstract}
The term macrostructure and its equivalents in other modern languages of culture has been used in dictionary research for the past more or less six decades. The use of this term by different researchers shows smaller or bigger differences according to the specific reference object. Currently there is no unified metalexicographic use of macrostructure and consequently a unified concept of macrostructure also lacks within dictionary research. II From the perspective of the philosophy of science it is not imperative to have only one concept in a specific discipline for a scientific object. A scientific pluralism could rather lead to findings, especially when the competing theoretical concepts constituting an object from different perspectives are clearly defined [...] (Wiegand and Gouws 2013: 74)
\end{abstract}

My initial point was that in order to be able to differentiate between, say, record as a noun, record as verb, and record as an adjective in a dictionary's macrostructure, knowledge about the word class and/or the morphology is also needed. Considering (part of) the comment on form as microstructural is only a convention. But, point taken, I guess that what I wrote was not based on conventional practice in any of the 'modern languages of culture', but rather the result of a lifetime of work in Bantu lexicography. In that regard, Polis's dictionary provides me with another good example of why I wish to stand by my point of view. Let us start with the traditional definition of the lemma sign:

Strictly speaking, the information contained in the microstructure does not refer to the lemma but to the linguistic sign which the lemma arbitrarily represents in the macrostructure. The sign may be called the lemma sign [...] (Hausmann and Wiegand 1989: 329)

If we now look back at Polis's dictionary, then we see that the arbitrary linguistic sign is simply what we termed the Vertical Base + Horizontal Base. Those two together, which we presented in bold type throughout this article, thus make up each lemma sign. Given that the sequence of all such lemma signs constitutes the macrostructure, it follows from Polis's approach that word class information (at Step 2 of the Horizontal Base) and morphology (at Step 3 of the Horizontal Base) are thus indeed part and parcel of a dictionary's macrostructure. There is (assuming purposeful dictionary consultation and not random browsing) in other words no way that one can arrive at any item in the dictionary's microstructure without passing through the macrostructure, and that macrostructure has word-class information as well as morphological information built into the very lemma signs!

This observation does not mean that no other word class or morphological information cannot appear in the microstructure - and in effect, we saw that it can - the point is that in order to get at the data, (some) word classes and (some) morphology have to be obligatory taken into account at the macro- 
structural level. Assuming that all comments on form are necessarily segmentable and distinct from the macrostructure, as suggested by Gouws (2014: 485486), is thus a faulty theoretical construct which is not rooted in actual practice. Or to paraphrase Michael Rundell's wonderful aphorism, this is yet another case of a lexicographic matter that works in practice but doesn't work in theory (Rundell 2012).

\subsection{On the nature of the access structure}

A dictionary's macrostructure is intimately linked with its outer access structures, as defined by Wiegand:

Informally one can distinguish as follows between macro- and access structures: each macrostructure contains as partial structures $n$ outer access structures (with $n \geq 1$ ); when $n=1$ a special case prevails, i.e. that the macro- and the only outer access structure (regarding the word list) of one and the same dictionary coincide, so that a mono-accessible dictionary with one (outer, index-external) access structure prevails. (Wiegand 1989: 393, Wiegand and Gouws 2013: 77)

In Polis's dictionary there is just one outer access structure, which means that the outer access structure and macrostructure coincide. The outer access structure itself may be defined as follows (again with reference to the latest definitional incarnation of this concept):

An outer access structure is a linear textual structure, whose elements are outer access text elements, which can be accessed externally through the knowledge of general dictionary-external and specifically defined dictionary-internal principles for the linear sequence of the access text elements. (Wiegand and Beer 2013: 113)

As was shown in Sections 3.1.2 (on the Vertical Base) and 3.1.3 (on the Horizontal Base) Polis's dictionary makes especially use of dictionary-internal principles for the linear sequence of the access text elements. Once a lemma sign is reached, the inner access structure takes over. In contrast to the outer access structure, however, there isn't much structure in the inner access structure of Polis's work. The various items to which the lemma signs lead are simply listed in no particular order, and as we saw in Section 3.2 (on the microstructure) both the exact position and the form of those items vary.

\subsection{On the nature of the access route}

Considering the entire access route which a dictionary user can follow to reach the actual lexicographical treatments of each item, one can conclude from the previous section that the innovative outer access structure provides for a rather fool-proof guidance, while the inner access structure is haphazard. 
The outer access structure, while rather fool-proof, is indeed not fully foolproof: During ideal dictionary consultation, a user should be able to look up a word without the need to know anything about that word. In Polis's work, this is not really the case. If one wishes to look up lufwá, for instance, should one go to the cluster L-f, LuF, or Fa in the Vertical Base? Reformulated, if one doesn't already know whether one is dealing with, say, an ideophone, a verb or a noun, each of those starting positions in the Vertical Base is 'correct'. Given that lufwá 'death' is a noun in class 11, the lemma sign is Fa + W, SUBST., tu (Part II, p. 45). No sooner has one mastered this as a user that one runs into trouble for nouns in other noun classes. The plural noun class 6 is a case in point. The noun maanga, for instance, shouldn't be looked up under the cluster $\mathbf{G a}$, but rather under the lemma sign MaG + OI, SUBST., ma (Part II, p. 228), as was seen in (36). And then there are the genuine doublets. Take for instance the word nyalu, should it be looked up under the cluster NaL or YaL? It turns out that it can be found under both: as siidi nyalu yiingi 'he/she disappeared hiding' under the lemma sign NaD \& NaL + YII, SUBST., zi (Part II, p. 514), and as nyalu 'row, layer' under the lemma sign YaD \& YaL + II, SUBST., zi (Part II, p. 617). The second outer access route here is actually the correct one. Another bone of contention concerns collocates, and the question of where they should be looked up (Bogaards 1990). Take for instance nzo tubu: It turns out that Polis covered this particular set under both constituents, as seen in (66) and (67), but this is by no means the general rule:

(66) Zo + O, SUBST., zi (Part II, p. 126): ... nzzo tubu, ensemble de 2 pièces d'étoffe cousues ensemble (d'environ $12 \mathrm{~m}$.) [outfit consisting of two lengths of cloth sewn together (of about $12 \mathrm{~m}$ )] ...

(67) TuB + OII, SUBST., ? (Part II, p. 429): nzo tubu, deux pagnes cousus en un seul [two loincloths sewn together as one]; twiiku.

The strict separation between the type of lexicographical information covered in the pre-grammatical section vs. the main section is also not always adhered to, as may be deduced from (68) vs. (69), where the verbal information (here regarding sweetama) is expounded on both in the pre-grammatical section (Part I), and in the main section (Part II):

(68) Set + WII, 4 (Part I, p. 59): sweetika, resserrement [of tightening]; v. sweetama; au moral aussi, de qqun "in 't nauw gebracht", serré de près dans une affaire [also figuratively, of someone (in Dutch) 'be put in a tight spot', be forced into an affair]; v. swetika. (swatata, mince [thin]; swetete, s'amincir avec effort [to get thinner with effort])

(69) SeT + WII, V.DER., aMA (Part II, p. 591):16 nnti usweetama ga nsuka boonso mbaambi nkay, le bois s'amincit à l'extrémité comme une corne (d'antilope) [the wood thins at the tip, like a horn (of an antelope)]; - kinkutu fiswetamene, le veston est étroit, serrant [the jacket is tight].

nnkaanda uwiidi sweetama, le papier s'est resserré, il reste peu de place pour écrire après tout ce qu'on a déjà écrit [the paper has narrowed, little space remains to 
write after everything we already wrote]; - bisona biswetamene, les lettres sont serrées, l'écriture est serrée [the letters are packed, the writing is compressed]; na swetika; - muuntu swetamene, qqn (est rétréci), on lui coupe la parole [someone 'is shortened', he is cut off (i.e., interrupted, stopped from speaking)]: susa; - muuntu usweetama mu maambu, qqn. est serré dans les affaires, à quia, pas d'issue! [someone is forced into the affairs, nonplussed, with no way out!]

By contrast, the route a user must follow to navigate the inner access structure of Polis's work is definitely challenging at times. Whenever the microstructural description of a certain item is limited to a single example, without the provision of a direct translation equivalent, the user will have to go back and forth between the Kintandu text and its French translation in order to extract the meaning. Doing so for the entry shown in (70), for instance, will hopefully lead to the meaning 'be able to be pulled' for the verb golakana:

(70) GoD \& GoL + OII, V.DER., aKA (Part II, p. 339): myo nnsiinga ka migolakana ko, ces lianes ne peuvent se tirer [these lianas cannot pull themselves] ...

Quite often, however, a substantial amount of cultural information needs to be negotiated in addition, as in (71), where the meaning for the verb suunguta 'to limp' has to be extracted from the wider context:

(71) SuG + OI, V.DER., uTA (Part II, p. 561): nsusu go yadi syeetuka, muuntu mpi yadidi suunguta, (pour soigner une jambe cassée, le féticheur met dans la maison du patient une poule à qui il a cassé et bandé la patte; les deux guériront ensemble), la poule quand elle commencera à se traîner, l'homme aussi commencera (à se mouvoir) [(in order to treat a broken leg, the fetish-priest puts in the house of the patient a chicken whose leg he broke and taped; the two will heal together), the chicken when it will start to drag itself, the person too will start 'to move'].

On occasion, Polis helps the reader by placing the (approximate) translation equivalent, rather idiosyncratically, between brackets, as seen in (71) - an approach which could also be seen in for instance (36), (53), (57) and (69) above. However, without any real structural markers in the microstructure - whether typographical (e.g., various typefaces and font sizes, the use of bold print vs. italics, etc.) or non-typographical (e.g., the use of numbering, various symbols, etc.) - the inner access route is bound to be more convoluted than it needs to be. The fact that there are also quite a number of typos when it comes to all matters punctuation, quotation marks and brackets doesn't help in this regard. ${ }^{17}$

The hardest part to work out in the microstructure remains the task to extract generic meanings when only a series of example phrases and/or collocates is presented, which thus implies going back and forth between each line of a microstructural entry. Some of those meanings will turn out to be related, others won't (cf., e.g., the Meaning column in Table 6). If a comparison with modern corpus-based/driven lexicography is allowed here, Polis thus provides us with the corpus evidence (i.e., collocations as well as short example 
sentences that his language consultants provided for each formula), and tends to leave it to the reader to deduce the meanings from this data. Those deductions are known to be the hard part of the work of a lexicographer (Hanks 2002), so this may also be one of the reasons why Polis does not refer to his work as a dictionary yet: both the items and the translation equivalents are still hidden and often only implicit in his work's microstructure. In a way, this state of affairs could be viewed as the reverse problem of the situation whereby dictionaries typically offer context-free answers to real-world context-sensitive questions:

I [...] demand that the future dictionary pay attention to the contexts in which the professional user needs dictionary help. In other words, I suggest that the only way to overcome the present user dilemma of general (context-free) answers to context-sensitive questions is to try to predict the reasons why the user looks up a particular headword and then try to provide a set of adequate answers. (Varantola 2002: 33)

Of course, Polis was never part of this metalexicographical discussion, but it is nonetheless interesting to note that his and his collaborators' intuition was to present actual data in context, rather than attempt to systematically abstract away that context. Whereas a typical bilingual dictionary's focus is the translation equivalent, that of Polis's dictionary is the illustrative material. That the access route, in the absence of pre-packaged ready-made answers, suffers in the process seems to be merely a trade-off. But does it work? Does Polis's dictionary describe items (in context) that a typical user may need? Does it also describe items (in context) that an advanced user may need? This is the topic of the next section.

\section{Practical evaluation of Polis's Lexique}

\subsection{Billions, millions or hundreds of thousands of combinations?}

The overarching question which remains to be answered is whether Polis's method and presentation actually succeeded in capturing and sharing the lexicon of Kintandu with any reasonable success. If someone were given the 26 letters of the Latin alphabet, and told that words may, say, contain up to eight letters, a fully blind approach would generate over 217 billion possibilities (i.e., $\left.26+26^{2}+26^{3}+26^{4}+26^{5}+26^{6}+26^{7}+26^{8}\right)$. Realizing that Bantu languages have a CV structure - and assuming $\mathrm{C}$ is a single letter also covering cases like CS, $\mathrm{NC}, \mathrm{NCS}, \mathrm{CH}$, etc. (with $\mathrm{S}$ the glides, $\mathrm{N}$ the nasals, and $\mathrm{H}$ aspiration) - this could immediately be reduced to about 123 million (i.e., $26+(21 \times 5)+(21 \times 5)^{2}$ $\left.+(21 \times 5)^{3}+(21 \times 5)^{4}\right)$. Of course, on the one hand words can be longer than eight letters, while on the other hand there are of course numerous combinatorial constraints in any language, which enable one to bring down that number 
substantially. This is exactly what Polis did. First, he realised that he doesn't need all the letters of the alphabet for an approximate description of Kintandu: $c, h, j, q, r$ and $x$ were not used. This is in line with Butaye (1910: 10-12), except that Butaye also uses $r$. Although Polis doesn't list $r$ as part of his alphabet, he does use it sporadically, especially for foreign words, as in Balaari (under the cluster LaD). A comparison with the phonemes in the various Kikongo varieties tabled by Laman (1936: xc-xci) indicates that $h$ could have been kept to indicate aspiration. In any case, with just 20 letters, of which 15 consonants and five vowels, and with the same assumption about $C$, the number of theoretically possible single-letter words and $\mathrm{CV}$-sequences up to eight letters goes down to about 32 million (i.e., $\left.20+(15 \times 5)+(15 \times 5)^{2}+(15 \times 5)^{3}+(15 \times 5)^{4}\right)$. Second, Polis also took Bantu morphology into account, and as we saw he builds everything around single $\mathrm{CV}(\mathrm{C})$ clusters - his Vertical Base. In reality, Bantu word roots are not limited to $\mathrm{CV}(\mathrm{C})$ clusters and may be longer, but he takes care of the longer ones in his Horizontal Base. Indeed, his CV(C) structures of the Vertical Base do not normally take noun class prefixes into account, nor any suffixes (i.e., verbal extensions, and others). These are taken care of in paradigmatic fashion in Steps 2 and 3 of the Horizontal Base, which further brings down the random variation. Disregarding diphthongs and vowel length to simplify the present thought experiment, the maximum number of $C V(C)$ structures in the pre-grammatical and main sections would then be $2 \times((15 \times 5)$ $+(15 \times 5 \times 15))$ or two series of $1200 \mathrm{CV}(\mathrm{C})$ clusters. Polis actually ended up with 1592 clusters in the Vertical Base (cf. Section 3.1.2), 527 of which in Part I and 1065 in Part II. Each of the 1065 CV(C) clusters in Part II was subjected to the six Step 1 combinations of palatalization, labialization and prenasalization (cf. Code 2 in Table 2), and for each of these also the Step 3 variation, thus the seven main noun prefixes on the one hand (cf. Table 3) and the more than 30 main extensions on the other (cf. Table 4). Together with the base verbs and varia from Step 2, that's still about 300000 combinations that must have been tried out in Part II. Given the absence of base verbs and noun classes in Part I, as well as generally fewer extensions and no varia, the number of pre-grammatical combinations tried out may have been around 30000 . Of the total of 330000 combinations, it is estimated that no more than about 5\% resulted in actual words and were subsequently treated in Polis's work.

In order to evaluate the eventual selection, one would ideally be able to compare it with Kintandu corpus data. This is problematic for a number of reasons, chief among them the idiosyncratic spelling adopted by Polis. Amongst others Polis tends to double vowels in environments of compensatory lengthening (i.e., V:NC and CSV:) whereas others don't mark this as it's predictable, he uses $y$ for glides whereas others use $i$, he doesn't mark tone whereas several others do, etc., but in contrast he for instance differentiates between the syllabic vs. non-syllabic homorganic nasals (at noun level) whereas others don't. ${ }^{18}$ Nonetheless, what is feasible to do is to compare Polis's work with Butaye's dictionary, and vice versa. Two tests to this end are discussed next. 


\subsection{Test 1: Polis vs. Butaye}

Butaye's (1909) dictionary consists of a number of sections; the part which interests us here is the first, i.e., the Kintandu-French direction. Compared to that section, Polis's work is about three times larger. Given that Butaye brought together around 8300 lemma signs for Kintandu, but also that the treatment for each lemma sign in Polis is much more extensive, with most of Polis's lemma signs leading to multiple items in the microstructure, the assumption is that Polis covers more of the Kintandu lexicon than Butaye does. As a first test to check this hypothesis, we took every tenth page in Polis's work, selected the top item on each of those pages, and checked whether or not it is also covered by Butaye. The data for this test is shown in Addendum 5 .

Of the 71 test items from Polis, as many as 27 have no equivalent in Butaye. For 6 of those who have, the correspondence is furthermore only approximate. Extrapolating from this random sample, anything between $54 \%$ and $62 \%$ of the material from Polis is also covered by Butaye, while $38 \%$ up to $46 \%$ isn't. For the pre-grammatical items, the correspondence is even lower: only two (one of which dubious) of the seven Polis items is also included in Butaye. Here the overlap is thus a mere $14 \%$ to $29 \%$.

While some of the missing items clearly belong to the fringes of common vocabulary, such as the ideophones $k y u$ and $z w e$ for the sound the throat makes when one swallows, respectively the instance of a thorn entering the body, or the verb kedingiinza used for the pounding in small double beats such as that of one's heart, others seem much more common, such as the ideophone $z u b u$ to refer to intelligence or vigilance, the noun ntuuta for a quarrel, or even the verb vidika used to say something in a round-about way. If anything, this clearly indicates that Polis's dictionary contains a good number of unique items, especially ideophones and words derived from them, not covered by the otherwise excellent dictionary of Butaye.

\subsection{Test 2: Butaye vs. Polis}

A comparison of Butaye's dictionary with Polis's work has the potential to be even more revealing, as Butaye's dictionary can be treated as a corpus whose main lexical material ought to be in Polis's work. In this regard we are rather fortunate that Butaye took the trouble to mark all the main lemma signs in his dictionary with tramlines (i.e., two vertical parallel lines $\|$ ), ${ }^{19}$ leaving the common ones unmarked, while also marking dialectal/local forms with an asterisk $\left.{ }^{*}\right)$. About one fifth of Butaye's lemma signs are preceded by tramlines. In order to obtain a sufficiently large and balanced sample the following procedure was followed: we selected the first lemma sign from each page, but exploiting Butaye's frequency indications, we consistently took the first unmarked word (i.e., lemma sign) from an even-numbered page and the tramline-marked word from an odd-numbered page. The focus was also on true words rather than 
formatives and affixes, and those words also had to have a (recoverable, e.g. through cross-referencing) meaning. This procedure resulted in a set of 154 main (i.e., supposedly frequent) words, and 154 common (i.e., supposedly less frequent) words. Each of these was then looked up in Polis's dictionary, where we searched for 'the same word' (with either the same or an adapted spelling) having 'the same meaning' (broadly defined) and 'the same word class' (glossing over erroneous class assignations in either work). In the process, the practicability of Polis's innovative outer access structure was also tested. The full data set for this extensive test is shown in Addendum 6, which immediately reveals that Polis's dictionary can indeed successfully be used as a proper dictionary. From a user's perspective, this is an important result, one which can only be considered valid following such an extensive test.

Overall, $73 \%$ of the lemma signs from Butaye could be found as items in Polis. A further $4 \%$ were used throughout the dictionary but were not listed following their logical position in Polis's macrostructure, while for $7 \%$ of the lemmata a related item could be found in the macrostructure. Overall, then, just $16 \%$ of the material from Butaye could not be found in Polis at all. This stands in sharp contrast with the $38 \%$ to $46 \%$ of the material from Polis which could not be found in Butaye. A quick back-of-the-envelope calculation may now even suggest the number of items in Polis's dictionary. If up to $84 \%$ of the 8300 lemmata in Butaye can eventually be found in Polis, these $8300 \times 0.84$ or about 7000 items must also be in Polis. If 7000 items can be seen, the first test tells us that this represents only $54 \%$ to $62 \%$ of what is really covered, which suggests that Polis contains about 12000 items.

These are the overall figures. When the data is split up according to main lemmata vs. common lemmata, as done in Table 9 and Figure 2, a highly interesting pattern emerges. Indeed, while as many as $73 \%$ of the Butaye lemmata can be looked up directly in Polis, there is a marked difference between the findability of frequent vs. less-frequent parts of the lexicon, with Polis covering as many as $87 \%$ of the frequent ones, but only $60 \%$ of the less-frequent ones. From the point of view of the material that cannot be found at all, the difference is even more marked, with just $5 \%$ of the main material not covered in Polis vs. $27 \%$ of the common material.

Table 9: Butaye lemmata vs. Polis items: Statistics for the full sample

\begin{tabular}{lrrrrrr}
\hline Butaye lemma is ... & \multicolumn{2}{c}{ Full sample } & \multicolumn{2}{c}{ Main lemmata } & \multicolumn{2}{c}{ Common lemmata } \\
& $\mathbf{N}$ & $\mathbf{\%}$ & $\mathbf{N}$ & $\mathbf{\%}$ & $\mathbf{N}$ & $\mathbf{\%}$ \\
\hline in Polis as item & 226 & $73 \%$ & 133 & $87 \%$ & 93 & $60 \%$ \\
used in Polis & 12 & $4 \%$ & 8 & $5 \%$ & 4 & $3 \%$ \\
related item in Polis & 21 & $7 \%$ & 5 & $3 \%$ & 16 & $10 \%$ \\
not in Polis & 49 & $16 \%$ & 8 & $5 \%$ & 41 & $27 \%$ \\
\hline SUM & 308 & $100 \%$ & 154 & $100 \%$ & 154 & $100 \%$ \\
\hline
\end{tabular}



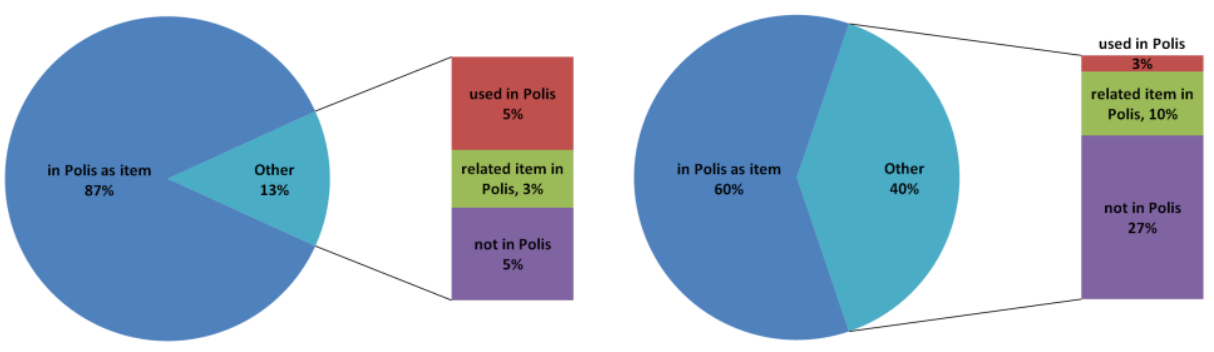

Figure 2: Butaye lemmata vs. Polis items: Main lemmata (left) vs. common lemmata (right)

While the macrostructural coverage of no two dictionaries can ever be the same (unless blatant copying is involved), one can expect any general language dictionary to cover at least the largest part of the frequent section of a language's lexicon. The left pie diagram shown in Figure 2 indicates that Polis succeeded well on this level.

Given that the sample extracted from Butaye also comes with part-ofspeech (POS) information, a further breakdown is possible in order to answer questions like: Which types of words did Polis typically miss, or conversely, which types did he tend to include at the expense of others? In other words, did Polis pay particular attention to nouns, or verbs, or perhaps any other word class? The answers to these questions are summarised in Figure 3 for the main lemmata and in Figure 4 for the common lemmata.

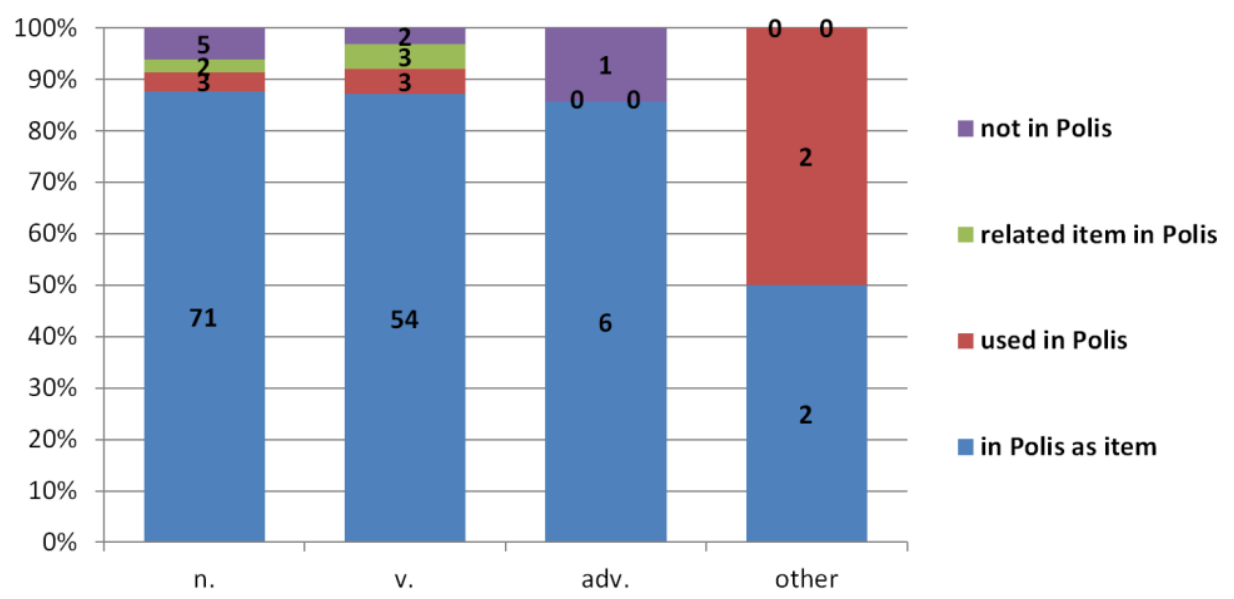

Figure 3: Main Butaye lemmata vs. Polis items: POS distribution (with the number of actual occurrences in the sample shown in the histograms) 


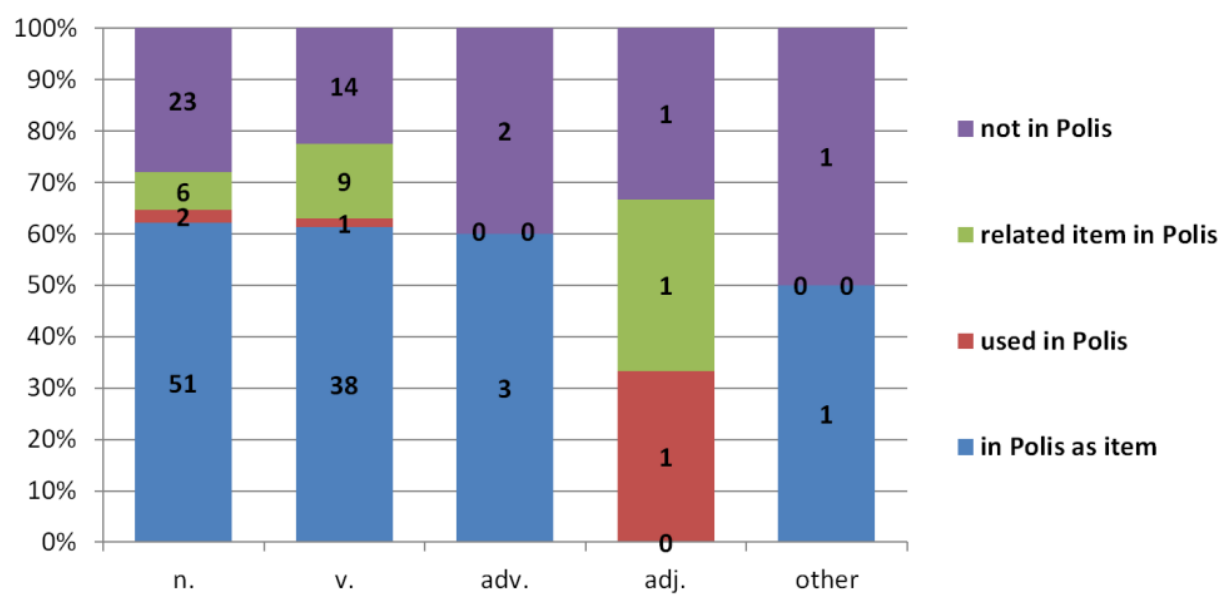

Figure 4: Common Butaye lemmata vs. Polis items: POS distribution (with the number of actual occurrences in the sample shown in the histograms)

Astonishingly, when it comes to the main word classes - nouns, verbs and adverbs - Polis seems to have been exceptionally consistent. While $87 \%$ of Butaye's material was directly included for the main lemmata overall, the distribution for these main lemmata across nouns, verbs and adverbs is respectively $88 \%, 87 \%$ and $86 \%$. Likewise, while $60 \%$ of Butaye's material was directly included for the common lemmata overall, the distribution for these common lemmata across nouns, verbs and adverbs is respectively $62 \%, 61 \%$, and $60 \%$. The values for the other word classes, as may be derived from the number of actual occurrences shown in the histograms of Figure 3 and Figure 4, are too low to have any statistical value. These tests, then, not only show that Polis approached the compilation of his dictionary with military precision, but also and more importantly that he truly managed to capture the general-language lexicon of Kintandu as well as the more peripheral one (in the pre-grammatical section).

The answer to the question "Does it work?" is thus a resounding "Yes." At the same time, it is clear that his approach is thoroughly user-unfriendly for any real-world dictionary user. So what could have been Polis's underlying motives? We try to answer this in the next section.

\subsection{Polis's underlying motives}

Polis begins the introduction to his dictionary with the following paragraph, which in truth should be seen as a teaser, as its contents only make sense once one has painstakingly studied his dictionary: 
Les présentes listes ne sont pas un dictionnaire; elles n'en sont que la préparation. Elles constituent un instrument de travail; elles permettent la recherche systématique des formes manquantes; elles rendent plus aisée la comparaison des formes entre elles, en comparaison verticale des mots d'une même racine, en comparaison horizontale d'un même échelon dans les racines différentes; plus aisée aussi la comparaison avec les correspondants dans des dialectes et des langues apparentés; lesquelles comparaisons permettront de préciser le sens des éléments. [The present lists are not a dictionary; they are but their groundwork. They constitute a tool; they allow for the systematic search of the missing forms; they facilitate the comparison of the forms amongst one another, by means of a vertical comparison for the words with the same roots, and by means of a horizontal comparison for the same paradigm applied to different roots; they also facilitate the comparison with cognates in related dialects and languages; all of which will enable one to clarify the sense of the items.] (Polis 1938: i)

Even though Polis himself prefers not to see his work as a dictionary (yet), we have chosen to do so, as any modern dictionary definition would recognise his work to be exactly that; for instance: "a dictionary may be defined as a lexicographic reference work that has been designed to fulfil one or more functions, contains lexicographic data supporting the function(s), and contains lexicographic structures that combine and link the data in order to fulfil the function(s)" (Nielsen and Mourier 2007: 121). The main function of Polis's dictionary is to arrive at the best possible clarification of the various senses of an item. The lexicographic structures Polis developed for this goal have been expounded on at length in this article. With them, Polis firstly claims that "they allow for the systematic search of the missing forms". Although Polis has not succeeded in pinpointing all the items of Kintandu, his approach could certainly have revealed virtually all - probably given more time and a larger team, as it is known that no one person knows all the words and all their senses of a language. It is now indeed entirely feasible to run through the different formulas, to complete them where necessary, and to add the missing items.

Polis's second claim in the quoted opening paragraph summarises his core motive, namely to "facilitate the comparison of the forms amongst one another, by means of a vertical comparison for the words with the same roots, and by means of a horizontal comparison for the same paradigm applied to different roots". Unfortunately, the concept 'root' should not be understood in a true linguistic sense here, but even his blind, mechanical approach to vary $\mathrm{CV}(\mathrm{C})$ clusters and to combine them with affixes will obviously bring related material together. Take for instance the ZaZ cluster shown in Addendum 2 and summarised in Table 6. Going up and down vertically indeed reveals items that are likely related morphologically, such as -zyanzamene 'be straight' and nnzyaasi 'a straight thing', dinzanza 'small boat' and nzaanza 'whale boat, steel boat', nzaanza 'line' and zaanzama 'be in line, to make a line', zaanzaba 'to crawl (snakes, insects, ...)', zaanzala 'to crawl; ...?' and bizaanzala 'that which crawls (insects, ants)', etc. Recalling that the pre-grammatical material actually belongs with the main material, one should also extent the vertical discovery path from ZaZ to Zaz, 
shown in Addendum 4 and summarised in Table 8, whereupon one may for instance want to link mazaaza 'hoarse' in Part II with zazaza 'of trembling (arrow, lightning, dance, voice)' in Part I. The horizontal discovery path Polis suggests simply refers to the application of Steps 1 to 3 of the Horizontal Base: these steps are brought into position for each and every $\mathrm{CV}(\mathrm{C})$ structure, so cross-comparing the results will ultimately lead to the discovery of the morphological rules of the language.

Polis's third claim in support for his approach refers to the fact that his lists "facilitate the comparison with cognates in related dialects and languages". This aspect is actually not well developed, and is certainly not unique to his approach. References to other KLC varieties and even other languages have indeed been included (see the paragraph following the variation discussed in (5) to (8) in Section 2 above), but they are not the result of treating those other varieties and languages in the way Polis does.

Should one now take Polis's suggestion seriously and proceed with the compilation of a 'classical' dictionary based on his 'raw material'? This could certainly be a worthwhile (and challenging) venture, but it is our contention that a digitised and searchable version of his work as it stands is far more intellectually stimulating to interact with. Already, this unique source joins the ranks of only a few other lexicographical reference works which challenge preconceived metalexicographical notions. This in itself makes Polis's manuscript one to cherish.

\subsection{Test 3: Keywords in Polis as compared to Butaye}

Tests 1 and 2 dealt with macrostructural issues, so in this last section of the practical evaluation we propose an attempt to qualify the microstructure by computational means. Due to the idiosyncratic orthography used by Polis, any automated method faces an uphill struggle. However, the microstructure is also full of French (whose orthography has eagerly been guarded by the French Academy since the mid-seventeenth century), and thereby provides a way out. We propose to look at the French translations in order to know more about the Kintandu contents throughout the dictionary. In actual fact we will also look at the Kintandu in the process, but we do not expect the results for it to be very revealing. We are especially interested in knowing in what way the microstructural contents of Polis differ from those of Butaye.

We proceeded as follows: a text corpus was prepared containing the full text of Polis, bar the introduction, and another text corpus was prepared consisting of the full text of the Kintandu-French direction from Butaye. Both corpora thus consisted of material in Kintandu and French. Wordlists were drawn up for each text corpus, the result of which was a list of all the Kintandu and French words in the respective texts, together with the frequencies for each of those words as used in the respective dictionaries. The two frequency lists were then compared to one another, using the KeyWords function of WordSmith 
Tools (Scott 1996-2015). The overall statistics for these two text corpora are given in Table 10, from which it may be seen that both behave similarly: for each 1000 words added, Polis contains an average of 55.65 unseen words, while Butaye contains an average of 56.64 unseen words. The difference is just a single word, so Polis is only slightly more repetitive (or less original in its variation of word choice).

Table 10: Overall statistics for the Polis and Butaye text corpora

\begin{tabular}{llccll}
\hline & $\begin{array}{l}\text { Items (Polis) } \\
\text { Lemma signs (Butaye) }\end{array}$ & Tokens & Types & $\begin{array}{l}\text { STTR } \\
(1000)\end{array}$ & STTR std. dev. \\
\hline Polis & $\pm 12,000$ & 319,552 & 47,603 & 55.65 & 45.26 \\
Butaye & $\pm 8,300$ & 107,662 & 24,108 & 56.64 & 42.49 \\
\hline
\end{tabular}

(with STTR = standardised type-token ratio; std. dev. = standard deviation)

For a word to be considered a keyword in Polis, it had to occur at least three times in his dictionary. WordSmith Tools's KeyWords function calculates socalled keyness values, for which we used the log-likelihood statistical test and set the probability to $\leq 0.000001$, meaning that each keyword's appearance had a chance of only one in a million of not being statistically significant (Taljard and De Schryver 2002: 52). Abbreviations and the dictionaries' metalanguage were pruned from the resulting keyword list, as were function words, and for Kintandu also the keywords which are the result of the different spellings. The keyword list was divided into a French and Kintandu section, and each of these was again divided according to positive and negative keyness values. Positive keywords occur more often in Polis than would be expected by chance in comparison with Butaye; the occurrence of negative keywords is the reverse. In short, then, we trust that this method will allow us to characterise the microstructure of Polis's dictionary in comparison to Butaye's.

Rather than to now present long lists of words with their respective frequencies in the two text corpora, together with their actual keyness values and probabilities, we have opted for four word clouds generated with Wordle (Feinberg 2008-14), as what interests us here is to get an instant picture of the differences. ${ }^{20}$ The relative size of the keywords shown in the word clouds is in proportion to their keyness values, and they have mostly been arranged in alphabetical progression (the standard A-to- $Z$ that is, not Polis's ordering).

From Figure 5 it is immediately clear that the most outstanding concepts in Polis are actually nondescript, as they refer to generic objects, animals and people: 'thing' (chose), 'animal, beast' (bête), 'child' (enfant), 'kid, child' (gamin), 'people' (gens), 'issues' (affaires), and 'kind, type, species (of)' (sorte (de)). When the concepts become descript they refer to non-verbal communication, strong feelings, or issues to do with face: 'look, appearance' (allure), 'feeling' (sensation), 'heart' (coeur), 'gesture' (geste), 'intensely' (intensément), 'body' (corps), 'rhythm' (rythme), 'empty' (vide), 'eyes' (yeux), 'mouth' (bouche), and 'strongly' (fortement). 


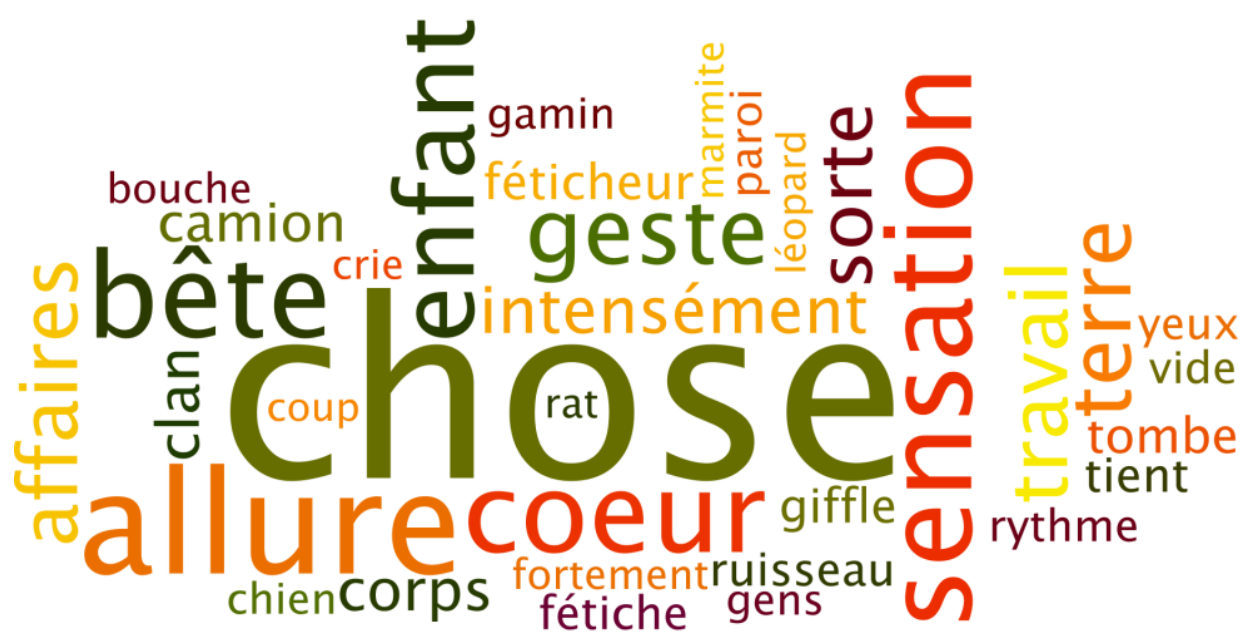

Figure 5: French positive keywords in Polis as compared to Butaye

Next up are those concepts that connect the Bantandu to mother earth, their social structures, and their close or cult animals: 'earth' (terre), 'stream, brook' (ruisseau), 'wall' (paroi), 'clan' (clan), 'fetish-priest' (féticheur), 'fetish' (fétiche), 'dog' (chien), 'rat' (rat), and 'leopard' (léopard). The words which refer to daily activities that stand out in Polis compared to Butaye include: 'job, work' (travail), 'slap, smack' (giffle), 'blow' (coup), 'fall' (tombe), 'hold' (tient), and 'shout, scream' (crie), as well as 'truck' (camion) and 'cooking pot' (marmite).

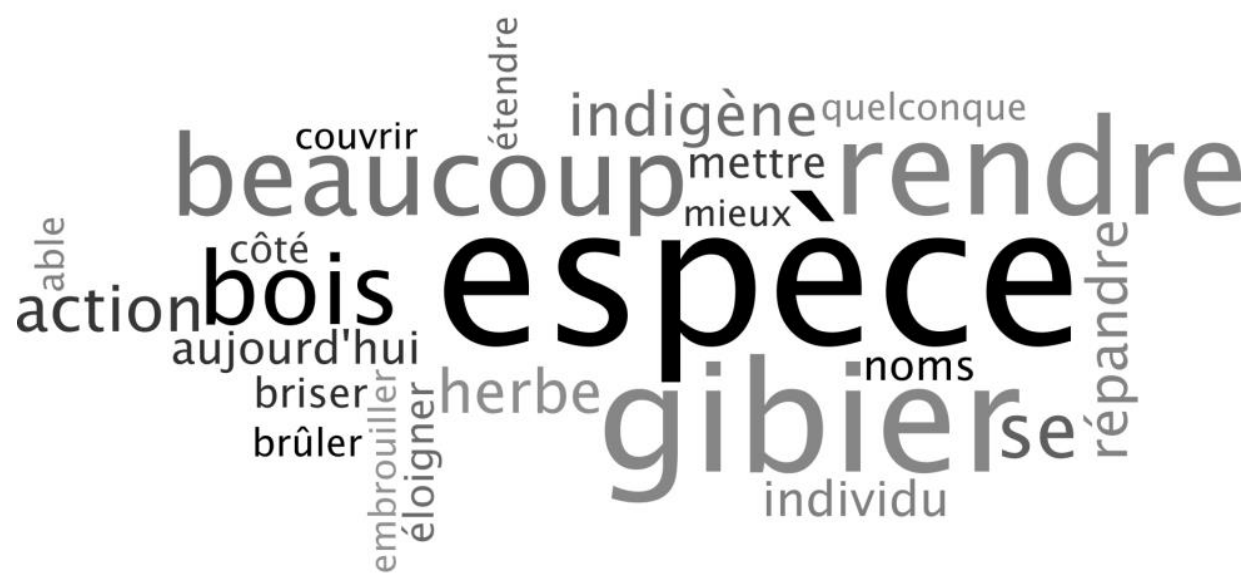

Figure 6: French negative keywords in Polis as compared to Butaye 
Figure 6 is the inverse of Figure 5 in that it shows us the concepts and words which Polis does not often use compared to Butaye. The nondescript words favoured by Butaye are simply the higher-register versions of some of those of Polis: 'species' (espèce), 'game, prey' (gibier), 'names' (noms) and 'any, some' (quelconque). The connection with mother earth is represented in Butaye by 'wood' (bois) and 'grass' (herbe). The activities underrepresented by Polis compared to Butaye are: 'to give back' (rendre), 'act' (action), 'to spill' (répandre), 'to put' (mettre), 'to move away' (éloigner), 'to break, to crush' (briser), 'to burn' (brûler), 'to spread out' (étendre), 'to muddle up, to tangle up' (embrouiller), and 'to cover' (couvrir). Characterisations are also often more specific and more individualistic in Butaye: 'a lot' (beaucoup), 'native, indigenous' (indigène), 'individual' (individu), 'today' (aujourd'hui), 'side' (côté), and 'better' (mieux), as well as '-self, each other' (se) and 'able (to)' (pouvoir (être)).

Overall, then, one may state that the material in Polis is closer to nature; wilder, less-polished and less-precise in its word use and activities described; deals with the deeper culture; and places more weight on the need to live in harmony, while condoning violence, stressing the importance to keep face, and avoiding the singling out of the individual.

Considering the limitations placed on an analogous exercise for the Kintandu words used throughout both dictionaries, Figure 7 confirms rather than disputes these findings.

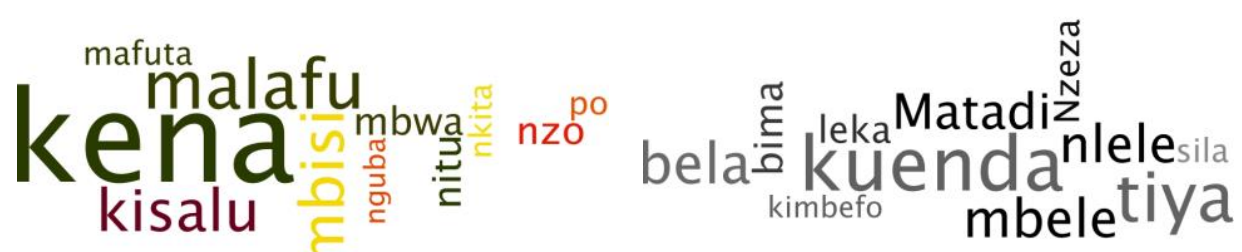

Figure 7: Kintandu positive (left) and negative (right) keywords in Polis as compared to Butaye

The positive keywords in Kintandu include: 'palm wine' (malafu), 'animal; meat' (mbisi), 'job, work' (kisalu), 'body; colour; form' (nitu), 'house' (nzo), 'dog' (mbwa), 'oil' (mafuta), 'fetish' (nkita), and 'peanut' (nguba). The fact that the ideophones 'of nothing' (kena) and 'of sound' (po) have a strong showing here, once more indicates the virtual absence of this word class from Butaye.

Kintandu words underused in Polis compared to Butaye include: 'to walk, to go' (kuenda), 'fire; heat' (tiya), 'to blame' (bela), 'knife' (mbele), 'material, fabric' (nlele), 'Matadi' (Matadi), 'things' (bima), 'to lie down' (leka), 'Nzeza (an indigenous 'saint')' (Nzeza), 'to put on' (sila), and 'illness' (kimbefo).

These few Kintandu keywords suggest a far more local concern in Polis than in Butaye, and related to this, Polis seems to refrain from over-comparing with the outside world: he simply lives among the Bantandu and describes 
what he notices from within the culture. Butaye, on the other hand, tries to bridge cultures, and looks at the Bantandu as an outsider. From the perspective of the user, Butaye's is the more user-friendly approach. From the perspective of the original culture, Polis's is the truest approach.

\section{Polis's Lexique and the most innovative outer access structure of any Bantu dictionary}

We set out to present a little-known dictionary manuscript for Kikongo, and showed that its contents are so unique that it more than deserves to be known and consulted as a dictionary in its own right. The material for this dictionary was brought together about a century ago, and typed up on over 700 pages in 1938 in Leuven, by the Jesuit missionary Charles Polis. Only a few of the stencil duplicated copies are still extant, and their readability is variable, but the data has now been digitised and is available for computerised searches. Polis worked in the Lower Congo region, east of the Inkisi River, and all the evidence - both dictionary-external and especially dictionary-internal - converges to pinpoint the particular variety described in the work as Kintandu, an eastern KLC (i.e., Kikongo Language Cluster) variety.

Our analysis of the structure of Polis's dictionary revealed a highly complex approach to the macrostructure, consisting of a Vertical Base + Horizontal Base. In simple terms, the Vertical Base is the sequence of all possible $\mathrm{CV}(\mathrm{C})$ clusters in the language. These clusters are listed in a non-standard ordering, which makes an index to the work highly desirable (for which see Addendum 1). These clusters vaguely resemble word roots. The Vertical Base consists of three steps. Step 1 is concerned with combinations of palatalization, labialization and prenasalization of each $\mathrm{CV}(\mathrm{C})$ cluster (for which codes are used, as seen in Table 2). Step 2 signposts the main word classes (base verbs, base nouns, derived forms (verbs, nouns, and others), and varia), which leads to differential variation in Step 3: noun class prefixes for the nouns (for which see Table 3), and extensions for the derived forms (for which see Table 4). The whole work is also divided into a short pre-grammatical section, Part I, which mainly deals with ideophones and derivations thereof, and the main section for all the other word classes, Part II. The macrostructure in Part I uses a simplified version of that from Part II. The same is true for the microstructure, where Part I mimics and simplifies what is done in Part II. On the whole, the focus in the microstructure is on presenting evidence (example phrases, collocations, etc.) together with translations into French, rather than on generic translation equivalents. Compared to the highly structured macrostructure, the microstructure is rather flat. The mediostructure mainly connects the relevant bits from Part II with those from Part I.

In the lexicographical appreciation we detailed how Polis must have interacted with his native-speaker collaborators, noting their every comment and hesitation, and also how he tried to differentiate between his main variety 
Kintandu and the neighbouring variety Kimbata. We further indicated how the main components of the traditional dictionary were nonetheless also covered in Polis's idiosyncratic dictionary: comments on form, comments on semantics, etymology, usage notes (in the extended microstructure), labels, and also encyclopaedic excursions into the culture and history of the Bantandu.

In the metalexicographical analysis we argued that even the latest definition for the concept 'macrostructure' that has emanated from the General-Theoryof-Lexicography school may not be correct. The sequence of lemma signs which constitute the macrostructure of Polis's dictionary consist of the combinations of the Horizontal Base + Vertical Base in each case, and thus necessarily imbed word class information and morphological information right into the very heart of the lemma signs, and hence also into the very heart of the macrostructure. There is no escaping this, and the insistence on assigning the comments on form to the microstructure is untenable. We further showed that in Polis's dictionary, the outer access structure and macrostructure coincide, and that while Polis makes especially use of dictionary-internal principles for the linear sequence of the access text elements, there isn't much structure in the inner access structure. As to the nature of the access route, once a user succeeds in reaching the entry they are looking up, the need to map meaning onto use takes over - a very modern lexicographic concept indeed (cf. Hanks 2002).

In the practical evaluation we first suggested that Polis and his team must have tried out well over 300000 combinations as candidate word forms, to eventually keep about 12000 'valid' items (i.e., real words) as the focus of their lexicographical descriptions. Three tests accompanied this evaluation, all involving Polis's dictionary on the one hand, and a contemporary Kintandu dictionary by Butaye (1909) on the other. These tests confirmed Polis to be an absolutely unique source: just $16 \%$ of the material from Butaye could not be found in Polis at all, while as much as $38 \%$ to $46 \%$ of the material from Polis could not be found in Butaye. Polis is especially strong on the so-called pregrammatical forms (i.e., ideophones, but also words for sounds and exclamations), and generally focuses more on the Bantandu in situ, while Butaye tends to contrast the Bantandu with the outside world. These subtle differences were revealed by means of a keyword study of the full Kintandu-French texts of these two dictionaries, the results of which were illustrated in the form of word clouds (for which see Figures 5 through 7).

From all of the above it should thus be clear that in addition to its intrinsic value as a highly informative lexicographic resource about a Kikongo variety for which there is otherwise very little data available, Polis's most important contribution to the lexicographic community at large is that he designed a truly unique outer access structure which forces all those interested in lexicographic theorising to go back to their drawing boards. In more practical terms, and returning to our three opening questions, we are now in a position to provide answers to them: (1) "Could this outer access structure be applied to all Bantu languages?" Yes, no question; but it can immediately be pointed out that if it 
were done with more linguistic insight and if the usual alphabetical ordering were used, a far better product would be the result. (2) "Is this outer access structure perhaps universal?" No, not in its present form, given the approach assumes open syllable structures, more specifically CVCV sequences, and includes Bantuesque features like a system of noun classes and (verbal) extensions. (3) "Could such an outer access structure perhaps be a solution for all non-corpus-based lexicographic endeavours?" The question is thus whether an - obviously language-dependent - atomic approach could be designed whereby all types of permutations are tried out in order to 'find' all the words of a language's lexicon. This certainly seems feasible theoretically, but in this day and age of large electronic corpora we see no need for it. Polis's attempt, however, is testimony to what some were capable of in the pre-corpus era, including in the absence of the tens of thousands of paper slips which were otherwise common in the lexicographic backrooms of the time. Polis truly came up with a system whereby he could, without access to any draft material, work through the alphabet and hardly miss any word - literally conjuring up a language out of thin air.

\section{Acknowledgements}

The research for this article was funded by Starting Grant No. 284126 of the European Research Council and by the Special Research Fund of Ghent University.

\section{Endnotes}

1. Each of the sections of the manuscript is dated, as is the introductory material, with dates ranging from March 21, 1938 up to October 9, 1938 - see Table 1. Three of those dates are also accompanied by "Louvain", French for the city of Leuven.

2. Van de Casteele (1968: col. 827-828) mentions eight fascicules, as does the earlier Daeleman (1966: 7), but it must have been nine based on the current binding of the instalments as seen in the extant copies.

3. For readability of all cited material from Polis (1938), we have added formatting (bold, italics, underlining, proper spacing, etc.) as well as translations into English (between square brackets). Obvious typos have also silently been corrected. Some inconsistencies were left as is, however, such as the inconsistent notation of vowel length (e.g., mpyaata vs. mpyata), the use of 'qqun', 'qqn.' and 'qqn' as abbreviations for 'quelqu'un', etc. Sample pages from the actual manuscript may be seen in Addenda 2 and 3.

4. Frequency counts are lower-bound values, meaning that there may be more occurrences (which we haven't spotted).

5. 'BLR' stands for the Bantu Lexical Reconstructions database (Bastin et al. 2002), and the integer following it is the index number in that database. The abbreviation $\mathbf{N}$ stands for a syllabic homorganic nasal. 
6. Likely using the heavily reworked version by Van Wing and Penders (1928), cf. De Kind et al. (2012) for more information on this source.

7. By considering the subsequent steps of the outer access route, this infelicity may at least be explained, however.

8. However, for the plural class 10 the pronominal prefix (PP) zi- is used as label, rather than $\mathrm{N}$-, which leads to an alternative interpretation: the labels at the nouns show the plural PPs. This is indeed useful information, as PPs are used to form "connectives, substitutives, possessives, precessives, determinants, interrogatives, demonstratives and numerals" (Daeleman 1966: 212, our translation) with those nouns, but why show plurals, especially considering the fact that nouns are typically presented and illustrated in their singular forms in the text that follows?

9. For the variation seen in Kikongo/Kintandu at classes 1,3 and 4, as well as class 7, the reader is referred to the detailed exposition in Bostoen and De Schryver (2015).

10. Unfortunately, Polis does not draw this convention to its logical conclusion, as he doesn't use double nasals for the object concord of class 1, as in "bantombwele kuna gaata mu kufuundisa, on le fit monter au village pour l'accuser (chez le chef)" [they made him go up to the village to accuse him (at the chief's place)] (Part II, p. 427), where it should have been banntombwele for bantombwele.

11. There are some small errors on this level of the ordering, however. Question marks are also used to indicate uncertainty with regard to class membership.

12. Observe that there are some small errors on this level of the ordering as well.

13. Except for the term 'imperfective' (Nurse and Philippson 2006: 190-192), the terminology used here is that of Daeleman (1966), with the 'rollative' our coinage based on his discussion on p. 179.

14. Although there is a cross-reference at the reference position YI, PREGR. in the ZaZ cluster, there is no corresponding reference address in the Zaz cluster. Recall (see Table 1) that ZaZ was typed in before Zaz, which may explain this infelicity. Other similar dead cross-references from fascicule 4 onwards must be seen as errors though.

15. In at least one instance Daeleman $(1966: 175,190)$ copied over such a Dutch paraphrase: "spartelen om iets te bekomen" [to flounder in order to obtain something] (Part II, p. 336).

16. Observe that there is no cross-reference from the cluster SeT to the pre-grammatical cluster Set. This seems to be part of a more general issue; as such explicit cross-references (using $c f r$ antea [cf. previous]) seem to suddenly stop being used after KeF (Part II, p. 322).

17. Recall, however, cf. note 3 , that such typographical markers were added for the quoted material in this article, and that (most) errors were also corrected.

18. The differences in spelling will become clear from the data shown in Addenda 5 and 6 .

19. Observe that this use is the opposite of their function in the early OED, where they indicate words which are "alien or not yet naturalized" (Murray 1888: xxvi). See also Ogilvie (2008).

20. For another use of word clouds in metalexicography, see De Schryver (2012: 471-473). In practical lexicography, word clouds have been proposed (e.g., Bowker 2012: 384-385), but they have not actually been used to date. The closest to them are the wordmaps found in Wordnik (McKean et al. 2009-15), an extension of Dream no. 17 (De Schryver 2003: 165-166). 


\section{References}

Bastin, Y., A. Coupez, E. Mumba and T.C. Schadeberg (Eds.). 2002. Bantu Lexical Reconstructions 3 / Reconstructions lexicales bantoues 3. Tervuren: Royal Museum for Central Africa. Available online at http://www.africamuseum.be/collections/browsecollections/humansciences/blr.

Bentley, W.H. 1887. Dictionary and Grammar of the Kongo Language, as Spoken at San Salvador, the Ancient Capital of the Old Kongo Empire, West Africa / Compiled and Prepared for the Baptist Mission on the Kongo River, West Africa. London: Baptist Missionary Society; Trübner \& Co.

Bentley, W.H. 1895. Appendix to the Dictionary and Grammar of the Kongo Language, as spoken at San Salvador, the Ancient Capital of the Old Kongo Empire, West Africa / Compiled and Prepared for the Baptist Mission on the Kongo River, West Africa. London: Baptist Missionary Society; Kegan Paul, Trench, Trübner \& Co.

Bittremieux, L. 1922. Mayombsch idioticon, Deel I-II (Congo-Bibliotheek 10-11). Gent: Drukkerij Erasmus.

Bittremieux, L. 1927. Mayombsch idioticon, Deel III: Verbeteringen en Aanvullingen, Plantenkundige Woordenlijsten en Zakenregister (Congo-Bibliotheek 21). Brussels: Drukkerij Essorial.

Bogaards, P. 1990. Où cherche-t-on dans le dictionnaire? International Journal of Lexicography 3(2): 79-102.

Boone, O. 1973. Carte ethnique de la République du Zaïre, quart sud-ouest (Annales — Série in- $8^{\circ}$ Sciences humaines 78). Tervuren: Royal Museum for Central Africa.

Bostoen, K. and G.-M. de Schryver. 2015. Linguistic Innovation, Political Centralization and Economic Integration in the Kongo Kingdom: Reconstructing the Spread of Prefix Reduction. Diachronica 32(2): 139-185 + 13 pages of supplementary material online.

Bostoen, K., O. Ndonda Tshiyayi and G.-M. de Schryver. 2013. On the Origin of the Royal Kongo Title ngangula. Africana Linguistica 19: 53-83.

Bowker, L. 2012. Meeting the Needs of Translators in the Age of e-Lexicography: Exploring the Possibilities. Granger, S. and M. Paquot (Eds.). 2012. Electronic Lexicography: 379-397. Oxford: Oxford University Press.

Butaye, R. 1909. Dictionnaire kikongo-français, français-kikongo. Roulers: Jules De Meester.

Butaye, R. 1910. Grammaire congolaise. Roulers: Jules De Meester.

Daeleman, J. 1966. Morfologie van naamwoord en werkwoord in het Kongo (Ntandu) met ontleding van het foneemsysteem. Unpublished Ph.D. dissertation. Leuven: Katolieke Universiteit te Leuven.

Daeleman, J. 1983. Les réflexes du proto-bantu en ntándu (dialecte kóongo). Faïk-Nzuji Madiya, C. and E. Sulzmann (Eds.). 1983. Mélanges de culture et de linguistique africaines publiés à la mémoire de Leo Stappers: 331-397. Berlin: Dietrich Reimer Verlag.

De Kind, J., G.-M. de Schryver and K. Bostoen. 2012. Pushing Back the Origin of Bantu Lexicography: The Vocabularium Congense of 1652, 1928, 2012. Lexikos 22: 159-194.

Delplace, E. 1895. Éléments de la langue congolaise, suivis d'un choix de phrases graduées et de deux vocabulaires. Bruges: Desclée, De Brouwer et Cie.

De Schryver, G.-M. 2003. Lexicographers' Dreams in the Electronic-dictionary Age. International Journal of Lexicography 16(2): 143-199.

De Schryver, G.-M. 2008. A New Way to Lemmatize Adjectives in a User-friendly Zulu-English Dictionary. Lexikos 18: 63-91.

De Schryver, G.-M. 2009. The Lexicographic Treatment of Ideophones in Zulu. Lexikos 19: 34-54.

De Schryver, G.-M. 2010. Revolutionizing Bantu Lexicography - A Zulu Case Study. Lexikos 20: 161-201. 
De Schryver, G.-M. 2012. Trends in Twenty-five Years of Academic Lexicography. International Journal of Lexicography 25(4): 464-506 + 42 pages of supplementary material online.

De Schryver, G.-M. 2013. Tools to Support the Design of a Macrostructure. Gouws, R.H., U. Heid, W. Schweickard and H.E. Wiegand (Eds.). 2013. Dictionaries. An International Encyclopedia of Lexicography. Supplementary Volume: Recent Developments with Focus on Electronic and Computational Lexicography (Handbooks of Linguistics and Communication Science, HSK 5.4): 1384-1395. Berlin: Walter de Gruyter.

De Schryver, G.-M., R. Grollemund, S. Branford and K. Bostoen. 2015. Introducing a State-of-theart Phylogenetic Classification of the Kikongo Language Cluster. Africana Linguistica 21: 87162.

De Schryver, G.-M. and D.J. Prinsloo. 2000a. Electronic Corpora as a Basis for the Compilation of African-language Dictionaries, Part 1: The Macrostructure. South African Journal of African Languages 20(4): 291-309.

De Schryver, G.-M. and D.J. Prinsloo. 2000b. Electronic Corpora as a Basis for the Compilation of African-language Dictionaries, Part 2: The Microstructure. South African Journal of African Languages 20(4): 310-330.

De Schryver, G.-M. and D.J. Prinsloo. 2001. Towards a Sound Lemmatisation Strategy for the Bantu Verb through the Use of Frequency-based Tail Slots - With Special Reference to Cilubà, Sepedi and Kiswahili. Mdee, J.S. and H.J.M. Mwansoko (Eds.). 2001. Makala ya kongamano la kimataifa Kiswahili 2000. Proceedings: 216-242, 372. Dar es Salaam: TUKI, Chuo Kikuu cha Dar es Salaam.

De Schryver, G.-M. and A. Wilkes. 2008. User-friendly Dictionaries for Zulu: An Exercise in Complexicography. Bernal, E. and J. DeCesaris (Eds.). 2008. Proceedings of the XIII EURALEX International Congress (Barcelona, 15-19 July 2008) (Sèrie Activitats 20): 827-836. Barcelona: Institut Universitari de Lingüística Aplicada, Universitat Pompeu Fabra.

Doke, C.M. 1935. Bantu Linguistic Terminology. London: Longmans, Green \& Co.

Feinberg, J. 2008-14. Wordle - Beautiful Word Clouds. Available online at: http://www.wordle. net/.

Gillet, J. and É. Pâque. 1910. Plantes principales de la région de Kisantu : Leur nom indigène, leur nom scientifique, leurs usages (Annales du musée du Congo belge / Botanique - Série V - Bas- et Moyen-Congo / Notes botaniques sur la région du Bas- et Moyen-Congo - Fascicule 1). Brussels: Ministère des Colonies.

Gouws, R.H. 2012. Theoretical Lexicography and the International Journal of Lexicography. International Journal of Lexicography 25(4): 450-463.

Gouws, R.H. 2014. Makrostruktuuraanpassings vanaf gedrukte na e-woordeboeke. Tydskrif vir Geesteswetenskappe 54(3): 481-504.

Gouws, R.H. and D.J. Prinsloo. 1998. Cross-referencing as a Lexicographic Device. Lexikos 8: 17-36.

Gouws, R.H. and D.J. Prinsloo. 2010. Thinking out of the Box - Perspectives on the Use of Lexicographic Text Boxes. Dykstra, A. and T. Schoonheim (Eds.). 2010. Proceedings of the XIV Euralex International Congress (Leeuwarden, 6-10 July 2010): 501-511. Leeuwarden: Fryske Akademy.

Hanks, P. 2002. Mapping Meaning onto Use. Corréard, M.-H. (Ed.). 2002. Lexicography and Natural Language Processing. A Festschrift in Honour of B.T.S. Atkins: 156-198. s.1.: Euralex.

Hausmann, F.J. and H.E. Wiegand. 1989. Component Parts and Structures of General Monolingual Dictionaries: A Survey. Hausmann, F.J., O. Reichmann, H.E. Wiegand and L. Zgusta (Eds.). 1989. Wörterbücher / Dictionaries / Dictionnaires. Ein internationales Handbuch zur Lexikographie / An International Encyclopedia of Lexicography / Encyclopédie internationale de lexicographie. Erster 
Teilband / First Volume / Tome Premier: 328-360. Berlin: Walter de Gruyter.

Kalonji, M.T.Z. 1993. Le lexicographie bilingue en Afrique francophone : l'example français-cilubà. Paris: Éditions L'Harmattan.

KongoKing Fieldwork. 2012. Linguistic fieldwork undertaken by Proff. K. Bostoen and G.-M. de Schryver, as well as their students J. De Kind and S. Dom, from August 4 to September 14, 2012, on ten Kikongo varieties spoken in the Lower Congo Province of the Democratic Republic of the Congo. Available online at: http://kongoking.org/fieldwork-linguistics-2012.html.

Laman, K.E. 1936. Dictionnaire kikongo-français, avec une étude phonétique décrivant les dialectes les plus importants de la langue dite kikongo (Institut royal colonial belge, Section des sciences morales et politiques, Mémoires - Collection in- $8^{\circ}$, Tome II). Brussels: Georges van Campenhout.

Makaya Lutumba, C. 1999. Éléments différentiels du ntandu et du manianga, dialectes kongo. Unpublished M.A. dissertation. Kinshasa: Institut Pédagogique National.

Makolo Miaka, J. 2000. Éléments de dialectologie kongo : esquisse comparative du kintandu, kiyombe et kimanyanga. Unpublished M.A. dissertation. Kinshasa: Institut Pédagogique National.

Mbatha, M.O. 2006. Isichazamazwi sesiZulu. Pietermaritzburg: New Dawn Publishers.

McKean, E., G. Barrett and O. Montoya. 2009-15. Wordnik — The World's Biggest Online English Dictionary. Available online at: https://www.wordnik.com/.

Murray, J.A.H. 1888. A New English Dictionary on Historical Principles: Founded Mainly on the Materials Collected by the Philological Society ... with the Assistance of Many Scholars and Men of Science. Volume I. A and B. Oxford: Clarendon Press.

Nielsen, S. and L. Mourier. 2007. Design of a Function-based Internet Accounting Dictionary. Gottlieb, H. and J.E. Mogensen (Eds.). 2007. Dictionary Visions, Research and Practice: Selected Papers from the 12th International Symposium on Lexicography, Copenhagen 2004 (Terminology and Lexicography Research and Practice 10): 119-135. Amsterdam: John Benjamins.

Nurse, D. and G. Philippson. 2006. Common Tense-Aspect Markers in Bantu. Journal of African Languages and Linguistics 27(2): 155-196.

Ogilvie, S. 2008. The Mysterious Case of the Vanishing Tramlines: James Murray's Legacy and the 1933 OED Supplement. Dictionaries: Journal of the Dictionary Society of North America 29: 1-22.

Polis, C. 1938. Lexique kikongo-français (manuscript in nine fascicules, stencil duplicated). Leuven.

Polis, C. 1942. Bij de Bakongo van Mbata. Aequatoria 5(3-4): 85-87.

Prinsloo, D.J. 2014. A Critical Evaluation of the Paradigm Approach in Sepedi Lemmatisation The Groot Noord-Sotho Woordeboek as a Case in Point. Lexikos 24: 251-271.

Prinsloo, D.J. and G.-M. de Schryver. 1999. The Lemmatization of Nouns in African Languages with Special Reference to Sepedi and Cilubà. South African Journal of African Languages 19(4): 258-275.

Rundell, M. 2012. It Works in Practice but Will it Work in Theory? The Uneasy Relationship between Lexicography and Matters Theoretical. Fjeld, R.V. and J.M. Torjusen (Eds.). 2012. Proceedings of the 15th EURALEX International Congress, 7-11 August, 2012, Oslo: 47-92. Oslo: Department of Linguistics and Scandinavian Studies, University of Oslo.

Scott, M. 1996-2015. WordSmith Tools. Available online at: http://www.lexically.net/wordsmith/.

Swartenbroeckx, P. 1973. Dictionnaire kikongo et kituba-français : vocabulaire comparé des langages Kongo traditionnels et véhiculaires (Ceeba Publications Série III, Vol. 2). Bandundu: Centre d'études ethnolinguistiques Bandundu.

Taljard, E. and G.-M. de Schryver. 2002. Semi-automatic Term Extraction for the African Lan- 
guages, with Special Reference to Northern Sotho. Lexikos 12: 44-74.

Van de Casteele, J. 1968. POLIS (Charles), Jésuite (Anvers, 1.11.1885 — Léopoldville, 27.6.1943). Jadot, J.-M. (Ed.). 1968. Biographie belge d'outre-mer, Vol. VI: col. 826-828. Brussels: Académie royale des sciences d'outre-mer.

Van Gheel, J. 1652. Vocabularium Latinum, Hispanicum, e Congense. Ad Usum Missionariorû transmittendorû ad Regni Congo Missiones (manuscript kept in the Biblioteca nazionale centrale di Roma: Fondi minori 1896, Mss. Varia 274).

Van Wing, J. and C. Penders. 1928. Le plus ancien dictionnaire bantu / Het oudste Bantu-woordenboek. Vocabularium P. Georgii Gelensis (Bibliothèque Congo / Congo Bibliotheek 27). Louvain: J. Kuyl-Otto.

Varantola, K. 2002. Use and Usability of Dictionaries: Common Sense and Context Sensibility? Corréard, M.-H. (Ed.). 2002. Lexicography and Natural Language Processing. A Festschrift in Honour of B.T.S. Atkins: 30-44. s.l.: Euralex.

Vermeersch, G. 1922. Dictionnaire tshiluba-français. Brussels: Librairie Albert Dewit.

Wiegand, H.E. 1989. Aspekte der Makrostruktur im allgemeinen einsprachigen Wörterbuch: Alphabetische Anordnungsformen und ihre Probleme. Hausmann, F.J., O. Reichmann, H.E. Wiegand and L. Zgusta (Eds.). 1989. Wörterbücher / Dictionaries / Dictionnaires. Ein internationales Handbuch zur Lexikographie / An International Encyclopedia of Lexicography / Encyclopédie internationale de lexicographie. Erster Teilband / First Volume / Tome Premier: 371-409. Berlin: Walter de Gruyter.

Wiegand, H.E. 1996. Über die Mediostrukturen bei gedruckten Wörterbüchern. Zettersten, A. and V.H. Pedersen (Eds.). 1996. Symposium on Lexicography VII. Proceedings of the Seventh International Symposium on Lexicography, May 5-6, 1994 at the University of Copenhagen (Lexicographica Series Maior 76): 11-43. Tübingen: Max Niemeyer.

Wiegand, H.E. and S. Beer. 2013. Access Structures in Printed Dictionaries. Gouws, R.H., U. Heid, W. Schweickard and H.E. Wiegand (Eds.). 2013. Dictionaries. An International Encyclopedia of Lexicography. Supplementary Volume: Recent Developments with Focus on Electronic and Computational Lexicography (Handbooks of Linguistics and Communication Science, HSK 5.4): 110-149. Berlin: Walter de Gruyter.

Wiegand, H.E., S. Beer and R.H. Gouws. 2013. Textual Structures in Printed Dictionaries: An Overview. Gouws, R.H., U. Heid, W. Schweickard and H.E. Wiegand (Eds.). 2013. Dictionaries. An International Encyclopedia of Lexicography. Supplementary Volume: Recent Developments with Focus on Electronic and Computational Lexicography (Handbooks of Linguistics and Communication Science, HSK 5.4): 31-73. Berlin: Walter de Gruyter.

Wiegand, H.E., M. Beißwenger, R.H. Gouws, M. Kammerer, A. Storrer and W. Wolski (Eds.). 2010. Wörterbuch zur Lexikographie und Wörterbuchforschung / Dictionary of Lexicography and Dictionary Research. Band 1: Systematische Einführung, A-C mit englishen Übersetzungen der Umtexte und Definitionen sowie Äquivalenten in neun Sprachen / Volume 1: Systematic Introduction, A-C with English Translations of the Outer Texts and Definitions as well as Equivalents in Nine Languages. Berlin: Walter de Gruyter.

Wiegand, H.E. and R.H. Gouws. 2013. Macrostructures in Printed Dictionaries. Gouws, R.H., U. Heid, W. Schweickard and H.E. Wiegand (Eds.). 2013. Dictionaries. An International Encyclopedia of Lexicography. Supplementary Volume: Recent Developments with Focus on Electronic and Computational Lexicography (Handbooks of Linguistics and Communication Science, HSK 5.4): 73-110. Berlin: Walter de Gruyter. 
Addendum 1: Vertical Base, or $\mathrm{CV}(\mathrm{C})$ sequence, of the macrostructure in the Lexique kikongo-français by Charles Polis (1938) [corrections and erroneous positions are marked in red]

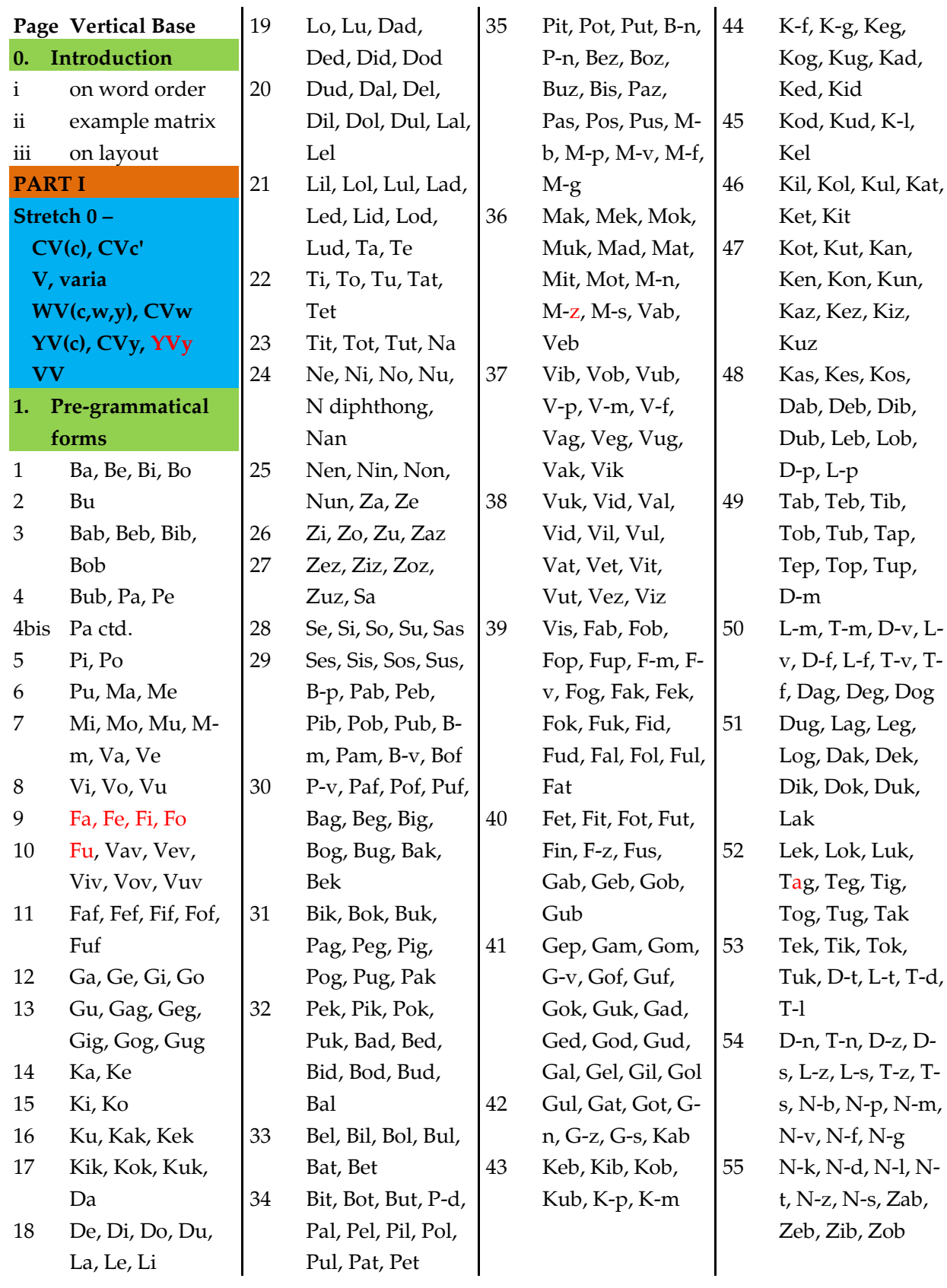




\begin{tabular}{|c|c|c|c|c|c|c|c|}
\hline \multirow[t]{4}{*}{56} & Zub, Sab, Seb, & 3 & $\mathrm{BaB}$ & 45 & $\ldots$ & 86 & Le, Li, Lo, Lu, \\
\hline & Sib, Sob, S-p, Z- & 4 & $\ldots$ & 46 & $\mathrm{Fe}$ & & Lau, DaD \\
\hline & m, S-m, S-v, S-f, & 5 & $\ldots$ & 47 & $\mathrm{Fi}, \mathrm{Fo}, \mathrm{Fu}, \mathrm{Foy}$ & 87 & $\ldots$ \\
\hline & Zag & 6 & $\ldots$ & 48 & $\mathrm{FaF}, \mathrm{FeF}$ & 88 & $\mathrm{DaL}$ \\
\hline \multirow[t]{3}{*}{57} & Zeg, Zug, Zak, & 7 & $\ldots$ & 49 & FiF, FoF & 89 & $\mathrm{LaL}$ \\
\hline & Seg, Sig, Sak, & 8 & $\ldots$ & 50 & $\mathrm{FuF}$ & 90 & $\mathrm{LaD}$ \\
\hline & Sek, Sik, Sok, Suk & 9 & $\ldots$ & 51 & $\mathrm{Ga}, \mathrm{Ge}$ & 91 & $\ldots$ \\
\hline \multirow[t]{4}{*}{58} & Zad, Zed, Zid, & 10 & $\ldots$ & 52 & Gi, Go, Gu, Gay & 92 & $\ldots$ \\
\hline & Zud, Zal, Zel, Zi, & 11 & Be & 53 & $\mathrm{GaG}$ & 93 & LaD, DeD \\
\hline & Zol, Zul, Zat, Zit, & 12 & $\mathrm{BeB}$ & 54 & $\ldots$ & 94 & DeL \\
\hline & Zot, Zut, Sad & 13 & $\ldots$ & 55 & $\mathrm{GeG}$ & 95 & LeL \\
\hline \multirow[t]{3}{*}{59} & Sed, Sod, Sud, & 14 & $\mathrm{Bi}, \mathrm{BiB}$ & 56 & $\ldots$ & 96 & LeD \\
\hline & Sal, Sel, Sol, Sul, & 15 & $\ldots$ & 57 & GiG, GoG & 97 & $\ldots$ \\
\hline & Sat, Set, Sot, Z-n & 16 & Bo & 58 & $\ldots$ & 98 & DiD \\
\hline \multirow[t]{2}{*}{60} & S-n, Z-s, S-s, a, e, & 17 & BoB & 59 & $\mathrm{GuG}$ & 99 & DiL \\
\hline & $\mathrm{i}, \mathrm{o}$ & 18 & $\ldots$ & 60 & $\ldots$ & 100 & LiL, LiD, DoD \\
\hline \multirow[t]{2}{*}{61} & $\mathrm{u}$, varia, $\mathrm{Wa}, \mathrm{Wi}$, & 19 & $\ldots$ & 61 & Ка & 101 & DoL, LoL, LoD \\
\hline & Wo, Wu & 20 & $\mathrm{Bu}, \mathrm{BuB}$ & 62 & $\ldots$ & 102 & DuD \\
\hline \multirow[t]{5}{*}{62} & W-b, Wag, Weg, & 21 & $\ldots$ & 63 & $\mathrm{Ke}, \mathrm{Ki}$ & 103 & DuL, LuL \\
\hline & Wog, W-k, W-d, & 22 & $\ldots$ & 64 & Ko & 104 & $\mathrm{LuD}$ \\
\hline & Wal, Wil, Wol, & 23 & $\ldots$ & 65 & Ku, Kau, Kay & 105 & $\ldots$ \\
\hline & Wul, W-t, W-n, & 24 & $\ldots$ & 66 & $\mathrm{KaK}$ & 106 & Ta \\
\hline & W-z & 25 & $\ldots$ & 67 & $\ldots$ & 107 & $\ldots$ \\
\hline \multirow[t]{3}{*}{63} & W-s, W-w, W-y, & 26 & $\mathrm{~Pa}$ & 68 & $\ldots$ & 108 & $\mathrm{Te}$ \\
\hline & B-w, Ya, Ye, Yi, & 27 & $\mathrm{Pe}, \mathrm{Pi}, \mathrm{Po}, \mathrm{Pu}$ & 69 & $\ldots$ & 109 & $\mathrm{Ti}$, To \\
\hline & Yo, Yu & 28 & $\mathrm{PaP}$ & 70 & $\ldots$ & 110 & $\mathrm{Tu}$ \\
\hline \multirow[t]{4}{*}{64} & Yab, Yeb, Yub, Y- & 28bis & $\ldots$ & 71 & $\mathrm{KeK}$ & 111 & $\mathrm{TaT}$ \\
\hline & p, Y-m, Y-v, Y-f, & 29 & $\mathrm{PeP}, \mathrm{PiP}$ & 72 & $\ldots$ & 112 & $\ldots$ \\
\hline & Yag, Yeg, Yig, & 30 & $\mathrm{PoP}$ & 73 & $\mathrm{KiK}$ & 113 & $\mathrm{TeT}$ \\
\hline & Yug & 31 & $\mathrm{PuP}$ & 74 & $\ldots$ & 114 & $\mathrm{TiT}$ \\
\hline \multirow[t]{4}{*}{65} & Yak, Yek, Yik, & 32 & $\ldots$ & 75 & KoK & 115 & ToT \\
\hline & Yok, Yuk, Yad, & 33 & Ma & 76 & $\ldots$ & 116 & $\mathrm{TuT}$ \\
\hline & Yed, Yid, Yod, Y- & 34 & $\mathrm{Me}, \mathrm{Mi}, \mathrm{Mo}, \mathrm{Mu}$ & 77 & $\ldots$ & 117 & $\cdots$ \\
\hline & l, Yil & 35 & $\mathrm{MaM}, \mathrm{MeM}$ & 78 & KuK & 118 & $\ldots$ \\
\hline \multirow[t]{3}{*}{66} & Yol, Yul, Y-t, Y-n, & 36 & MiM, MoM, & 79 & $\ldots$ & 119 & $\mathrm{Na}$ \\
\hline & Y-z, Y-s, B-y, V-y, & & $\mathrm{MuM}$ & 80 & $\ldots$ & 120 & $\mathrm{Ne}$ \\
\hline & K-y, L-y, Y-y & 37 & $\mathrm{Va}$ & & Simple \& double & 121 & $\mathrm{Ni}, \mathrm{No}, \mathrm{Nu}, \mathrm{N}-\mathrm{N}$ \\
\hline 67 & diphthongs & 38 & $\mathrm{Ve}$ & & inguals & 122 & $\ldots$ \\
\hline \multicolumn{2}{|c|}{ PART II } & 39 & $\mathrm{Vi}, \mathrm{Vo}, \mathrm{Vu}$ & 81 & $\mathrm{Da}$ & 123 & $\mathrm{NeN}$ \\
\hline \multicolumn{2}{|c|}{ Stretch $1-C V(C)$} & 40 & $\mathrm{VaV}, \mathrm{VeV}$ & 82 & $\ldots$ & 124 & $\mathrm{NiN}, \mathrm{NoN}, \mathrm{NuN}$ \\
\hline & Simple \& double & 41 & $\mathrm{ViV}, \mathrm{VoV}, \mathrm{VuV}$ & 83 & $\ldots$ & 125 & $\mathrm{Za}, \mathrm{Ze}$ \\
\hline & labials & 42 & $\ldots$ & 84 & De, Di & 126 & $\mathrm{Zi}, \mathrm{Zo}, \mathrm{Zu}, \mathrm{Zau}$ \\
\hline 1 & $\mathrm{Ba}$ & 43 & $\mathrm{Fa}$ & 85 & $\mathrm{Do}, \mathrm{Du}, \mathrm{La}$ & 127 & $\mathrm{ZaZ}$ \\
\hline 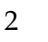 & $\ldots$ & 44 & $\ldots$ & & & 128 & ZeZ \\
\hline
\end{tabular}




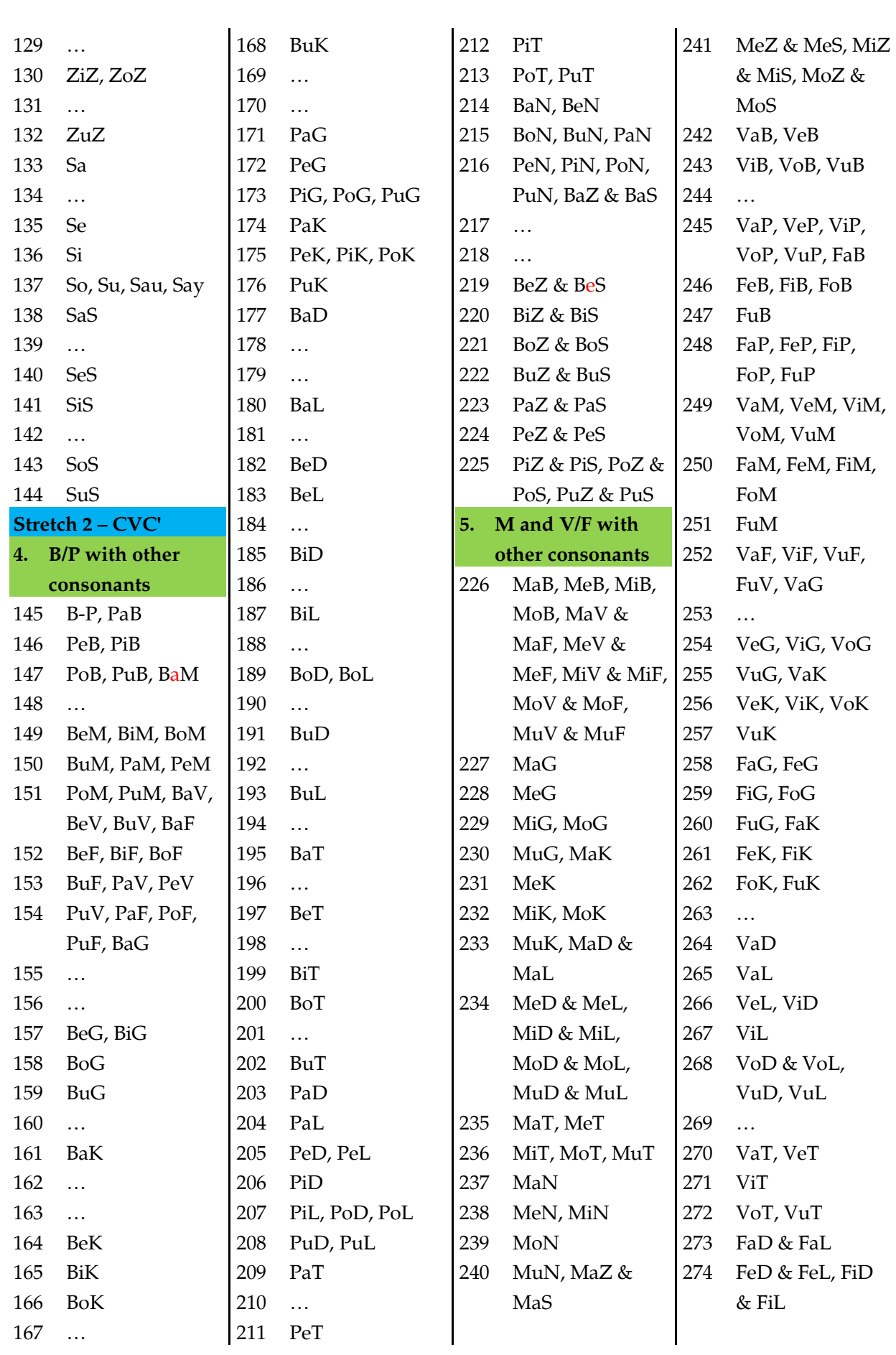




\begin{tabular}{|c|c|c|c|c|c|c|c|}
\hline \multirow[t]{2}{*}{275} & \multirow{2}{*}{$\begin{array}{l}\text { FoD \& FoL, FuD } \\
\& \mathrm{FuL}\end{array}$} & \multirow{2}{*}{$\begin{array}{l}310 \\
311\end{array}$} & $\cdots$ & 350 & $\ldots$ & \multicolumn{2}{|c|}{393 GuZ \& GuS } \\
\hline & & & $\ldots$ & 351 & $\ldots$ & 394 & $\mathrm{KaZ} \& \mathrm{KaS}$ \\
\hline 276 & $\ldots$ & 312 & $\mathrm{KaP}, \mathrm{KeP}, \mathrm{KoP}$ & 352 & $\ldots$ & 395 & $\ldots$ \\
\hline 277 & $\ldots$ & 313 & $\mathrm{KuP}, \mathrm{GaM}$ & 353 & $\mathrm{KeD} \& \mathrm{KeL}$ & 396 & $\ldots$ \\
\hline 278 & $\mathrm{FaT}$ & 314 & GeM, GoM, GuM & 354 & $\ldots$ & 397 & $\ldots$ \\
\hline 279 & $\ldots$ & 315 & $\mathrm{KaM}$ & 355 & $\ldots$ & 398 & $\ldots$ \\
\hline 280 & FeT, FiT & 316 & KeM, KiM, KoM & 356 & $\ldots$ & 399 & KeZ \& KeS \\
\hline 281 & $\ldots$ & 317 & $\mathrm{KuM}$ & 357 & $\ldots$ & 400 & $\ldots$ \\
\hline 282 & FoT, FuT & 318 & $\ldots$ & 358 & $\ldots$ & 401 & KiZ \& KiS \\
\hline 283 & $\cdots$ & 319 & $\mathrm{GaV} \& \mathrm{GaF}, \mathrm{GeV}$ & 359 & KiD \& KiL & 402 & KoZ \& KoS \\
\hline 284 & $\ldots$ & & $\& \mathrm{GeF}$ & 360 & $\ldots$ & 403 & $\ldots$ \\
\hline \multirow[t]{2}{*}{285} & \multirow{2}{*}{$\begin{array}{l}\text { VaN, VeN, ViN, } \\
\text { VoN, VuN }\end{array}$} & \multirow[t]{4}{*}{320} & $\mathrm{GiV} \& \mathrm{GiF}, \mathrm{GoV}$ & 361 & KoD \& KoL & 404 & KuZ \& KuS \\
\hline & & & $\& \mathrm{GoF}, \mathrm{GuV} \&$ & 362 & $\ldots$ & 405 & $\ldots$ \\
\hline 286 & $\mathrm{FaN}, \mathrm{FeN}, \mathrm{FiN}$ & & $\mathrm{GuF}, \mathrm{KaV}, \mathrm{KeV}$, & 363 & $\ldots$ & 406 & $\ldots$ \\
\hline 287 & FoN, FuN & & $\mathrm{KiV}, \mathrm{KoV}$ & 364 & $\ldots$ & \multirow{2}{*}{\multicolumn{2}{|c|}{$\begin{array}{l}\text { 7. D L/T with other } \\
\text { consonants }\end{array}$}} \\
\hline \multirow[t]{2}{*}{288} & VaZ \& VaS, VeZ & 321 & $\mathrm{KuV}, \mathrm{KaF}$ & 365 & $\ldots$ & & \\
\hline & $\& \mathrm{VeS}$ & 322 & $\mathrm{KeF}, \mathrm{KoF}, \mathrm{KuF}$ & 366 & $\ldots$ & 407 & $\mathrm{DaB} \& \mathrm{LaB}$ \\
\hline \multirow[t]{3}{*}{289} & ViZ \& ViS, VoZ & 323 & $\mathrm{GaK}$ & 367 & $\mathrm{KuD} \& \mathrm{KuL}$ & 408 & $\ldots$ \\
\hline & \& VoS, VuZ \& & 324 & GeK, GiK, GoK & 368 & $\ldots$ & 409 & $\ldots$ \\
\hline & VuS & 325 & GuK & 369 & $\ldots$ & 410 & DeB \& LeB \\
\hline \multirow[t]{2}{*}{290} & $\mathrm{FaZ} \& \mathrm{FaS}, \mathrm{FeZ} \&$ & 326 & $\mathrm{KaG}$ & 370 & $\ldots$ & 411 & $\ldots$ \\
\hline & $\mathrm{FeS}$ & 327 & $\ldots$ & 371 & $\ldots$ & 412 & $\ldots$ \\
\hline \multirow[t]{2}{*}{291} & FiZ \& FiS, FoZ \& & 328 & $\ldots$ & 372 & $\mathrm{KaT}$ & 413 & $\mathrm{DiB} \& \mathrm{LiB}$ \\
\hline & FoS, FuZ \& FuS & 329 & $\ldots$ & 373 & $\ldots$ & 414 & $\ldots$ \\
\hline 292 & $\ldots$ & 330 & $\mathrm{KeG}$ & 374 & $\mathrm{KeT}$ & 415 & DoB \& LoB \\
\hline \multirow[t]{2}{*}{6.} & G/K with other & 331 & $\mathrm{KiG}$ & 375 & $\ldots$ & 416 & DuB \& LuB \\
\hline & consonants & 332 & KoG & 376 & KiT & 417 & $\mathrm{DaP} \& \mathrm{LaP}, \mathrm{DeP}$ \\
\hline 293 & $\mathrm{GaB}$ & 333 & $\ldots$ & 377 & $\ldots$ & & $\& \mathrm{LeP}$ \\
\hline 294 & $\mathrm{GeB}, \mathrm{GiB}, \mathrm{GoB}$ & 334 & $\mathrm{KuG}$ & 378 & KoT & 418 & DiP \& LiP, DoP \\
\hline 295 & $\mathrm{GuB}$ & 335 & $\mathrm{GaD}$ & 379 & $\ldots$ & & \& LoP, DuP \& \\
\hline 296 & $\mathrm{GaP}, \mathrm{GeP}, \mathrm{GoP}$ & 336 & GaL \& GaD & 380 & $\mathrm{KuT}$ & & $\mathrm{LuP}$ \\
\hline 297 & $\mathrm{GuP}, \mathrm{KaB}$ & 337 & GeD \& GeL, GiD & 381 & $\ldots$ & 419 & $\mathrm{TaB}$ \\
\hline 298 & $\ldots$ & 338 & GoD \& GoL & 382 & $\mathrm{GaN}$ & 420 & $\ldots$ \\
\hline 299 & $\ldots$ & 339 & $\ldots$ & 383 & $\mathrm{GeN}, \mathrm{GiN}$ & 421 & $\ldots$ \\
\hline 300 & $\ldots$ & 340 & $\mathrm{GuD} \& \mathrm{GuL}$ & 384 & GoN, GuN, KaN & 422 & $\ldots$ \\
\hline 301 & $\ldots$ & 341 & $\mathrm{GaT}$ & 385 & $\ldots$ & 423 & $\ldots$ \\
\hline 302 & $\mathrm{KeB}$ & 342 & $\mathrm{GeT}$ & 386 & $\ldots$ & 424 & $\mathrm{TeB}$ \\
\hline 303 & $\ldots$ & 343 & GiT, GoT & 387 & $\mathrm{KeN}$ & 425 & $\mathrm{TiB}$ \\
\hline 304 & $\mathrm{KiB}$ & 344 & GuT & 388 & $\mathrm{KiN}$ & 426 & ToB \\
\hline 305 & КоB & 345 & $\mathrm{KaD} \& \mathrm{KaL}$ & 389 & $\mathrm{KoN}$ & 427 & $\mathrm{TuB}$ \\
\hline 306 & $\ldots$ & 346 & $\ldots$ & 390 & $\mathrm{KuN}, \mathrm{GaZ} \& \mathrm{GaS}$ & 428 & $\ldots$ \\
\hline 307 & $\mathrm{KuB}$ & 347 & $\ldots$ & 391 & GeZ \& GeS & 429 & $\ldots$ \\
\hline 308 & $\ldots$ & 348 & $\ldots$ & 392 & GiZ \& GiS, GoZ & 430 & $\mathrm{TaP}, \mathrm{TeP}$ \\
\hline 309 & $\ldots$ & 349 & $\ldots$ & & $\& \mathrm{GoS}$ & 431 & TiP, ToP, TuP \\
\hline
\end{tabular}




\begin{tabular}{|c|c|c|c|c|c|c|c|}
\hline 432 & DaM \& LaM & 467 & $\mathrm{TaK}$ & 496 & $\mathrm{NaB}, \mathrm{NeB}, \mathrm{NiB}$ & 528 & $\ldots$ \\
\hline \multirow[t]{2}{*}{433} & LeM, DiM, DoM & 468 & $\ldots$ & 497 & $\mathrm{NoB}, \mathrm{NuB}, \mathrm{NaP}$, & 529 & SeB \\
\hline & $\&$ LoM & 469 & $\mathrm{TeK}$ & & $\mathrm{NeP}, \mathrm{NiP}, \mathrm{NoP}$ & 530 & $\mathrm{SiB}$ \\
\hline \multirow[t]{2}{*}{434} & DuM \& LuM, & 470 & $\ldots$ & & $\mathrm{NuP}$ & 531 & SoB \\
\hline & $\mathrm{TaM}$ & 471 & TiK, ToK & 498 & NaM, NeM, NiM & 532 & $\mathrm{SuB}$ \\
\hline 435 & TeM & 472 & $\ldots$ & 499 & NoM, NuM, NaV & 533 & $\mathrm{SaP}$ \\
\hline 436 & TiM, ToM & 473 & TuK & & $\& \mathrm{NaF}, \mathrm{NeV} \&$ & 534 & $\mathrm{SeP}, \mathrm{SiP}, \mathrm{SoP}$ \\
\hline 437 & TuM & 474 & $\mathrm{DaT} \& \mathrm{LaT}$ & & $\mathrm{NeF}, \mathrm{NoV} \& \mathrm{NoF}$ & & SuP \\
\hline \multirow[t]{3}{*}{438} & D-V \& L-V, DaF & 475 & DeT \& LeT, DiT, & 500 & $\mathrm{NuV} \& \mathrm{NuF}$ & 535 & $\mathrm{ZaM}$ \\
\hline & \& LaF, DeF \& & & DoT \& LoT & & $\mathrm{NaG}$ & 536 & ZeM, ZiM \\
\hline & LeF & 476 & DuT \& LuT & 501 & $\ldots$ & 537 & $\mathrm{ZoM}, \mathrm{ZuM}, \mathrm{SaM}$ \\
\hline \multirow[t]{3}{*}{439} & DiF, DoF \& LoF, & 477 & $\mathrm{TaD} \& \mathrm{TaL}$ & 502 & $\ldots$ & 538 & SeM, SiM \\
\hline & $\mathrm{DuF} \& \mathrm{LuF}, \mathrm{TaV}$ & 478 & $\ldots$ & 503 & $\mathrm{NeG}$ & 539 & SoM, SuM \\
\hline & $\& \mathrm{TaF}$ & 479 & $\ldots$ & 504 & $\ldots$ & 540 & $\ldots$ \\
\hline \multirow[t]{3}{*}{440} & $\mathrm{TeV} \& \mathrm{TeF}, \mathrm{TiV}$ & 480 & $\ldots$ & 505 & $\mathrm{NiG}$ & 541 & $\mathrm{ZaV} \& \mathrm{ZaF} \&$ \\
\hline & $\& \mathrm{TiF}, \mathrm{ToV} \&$ & 481 & $\ldots$ & 506 & NoG & & $\mathrm{SaV} \& \mathrm{SaF}, \mathrm{ZoV}$ \\
\hline & ToF & 482 & $\mathrm{TeD} \& \mathrm{TeL}$ & 507 & $\mathrm{NuG}$ & & $\& \mathrm{ZoF} \& \mathrm{SoV} \&$ \\
\hline 441 & $\mathrm{TuV} \& \mathrm{TuF}, \mathrm{DaG}$ & 483 & $\ldots$ & 508 & $\ldots$ & & SoF \\
\hline & $\& \mathrm{LaG}$ & 484 & TiD \& TiL, ToD & 509 & $\mathrm{NaK}$ & 542 & $\mathrm{ZuV} \& \mathrm{ZuF} \&$ \\
\hline 442 & $\ldots$ & & $\& \mathrm{ToL}$ & 510 & $\mathrm{NeK}$ & & $\mathrm{SuV} \& \mathrm{SuF}, \mathrm{ZaG}$ \\
\hline 443 & DeG \& LeG & 485 & $\ldots$ & 511 & $\mathrm{NiK}$ & 543 & $\ldots$ \\
\hline 444 & $\ldots$ & 486 & $\mathrm{TuD} \& \mathrm{TuL}$ & 512 & NoK & 544 & $\mathrm{ZeG}$ \\
\hline 445 & $\ldots$ & 487 & $\ldots$ & 513 & $\mathrm{NuK}$ & 545 & $\mathrm{ZiG}$ \\
\hline 446 & $\ldots$ & 488 & DaN \& LaN, & 514 & $\mathrm{NaD} \& \mathrm{NaL}$ & 546 & ZoG \\
\hline 447 & DiG & & DeN \& LeN, & & $\mathrm{NeD} \& \mathrm{NeL}$ & 547 & $\mathrm{ZuG}$ \\
\hline 448 & DoG \& LoG & & DoN \& LoN, & & NoD \& NoL, & 548 & $\mathrm{ZaK}$ \\
\hline 449 & $\ldots$ & & DuN \& LuN, & & $\mathrm{NuD} \& \mathrm{NuL}$ & 549 & $\ldots$ \\
\hline 450 & DuG \& LuG & & TaN, TeN, TiN & & $\mathrm{NaT}$ & 550 & ZeK \\
\hline 451 & $\mathrm{DaK} \& \mathrm{LaK}$ & 489 & ToN, TuN & 515 & $\ldots$ & 551 & $\mathrm{ZiK}$ \\
\hline 452 & $\ldots$ & 490 & DaZ \& DaS \& & 516 & $\mathrm{NeT}, \mathrm{NiT}$ & 552 & ZoK \\
\hline 453 & DeK \& LeK & & LaZ \& LaS & 517 & NoT, NuT, NaZ & 553 & $\mathrm{ZuK}$ \\
\hline 454 & $\ldots$ & 491 & DeZ \& DeS \& & & $\& \mathrm{NaS}$ & 554 & $\mathrm{SaG}$ \\
\hline 455 & $\ldots$ & & LeZ \& LeS & 518 & NeZ \& NeS, NiZ & 555 & $\ldots$ \\
\hline 456 & $\mathrm{DiK}$ & 492 & DiZ \& DiS, DoZ & & $\& \mathrm{NiS}$ & 556 & $\mathrm{SeG}$ \\
\hline 457 & DoK \& LoK & & \& DoS \& LoZ \& & 519 & NoZ \& NoS & 557 & $\ldots$ \\
\hline 458 & $\ldots$ & & LoS & 520 & $\mathrm{ZaB}$ & 558 & $\mathrm{SiG}$ \\
\hline 459 & DuK \& LuK & 493 & DuZ \& DuS \& & 521 & $\ldots$ & 559 & SoG \\
\hline 460 & $\cdots$ & & LuZ \& LuS & 522 & $\mathrm{ZeB}$ & 560 & $\mathrm{SuG}$ \\
\hline 461 & $\mathrm{TaG}$ & 494 & TaZ \& TaS, TeZ & $522 \mathrm{bis}$ & s $\mathrm{ZiB}$ & 561 & $\mathrm{SaK}$ \\
\hline 462 & $\ldots$ & & $\& \mathrm{TeS}$ & 523 & $\mathrm{ZoB}$ & 562 & $\ldots$ \\
\hline 463 & $\mathrm{TeG}, \mathrm{TiG}$ & 495 & TiZ \& TiS, ToZ \& & 524 & $\mathrm{ZuB}$ & 563 & $\ldots$ \\
\hline 464 & ToG & & ToS, TuZ \& TuS & 525 & $\mathrm{SaB}$ & 564 & $\ldots$ \\
\hline 465 & $\mathrm{TuG}$ & 8. & $\mathrm{~N}$ and $\mathrm{Z} / \mathrm{S}$ with & 526 & $\ldots$ & 565 & SeK \\
\hline 466 & $\ldots$ & & ther consonants & 527 & $\ldots$ & 566 & $\ldots$ \\
\hline
\end{tabular}




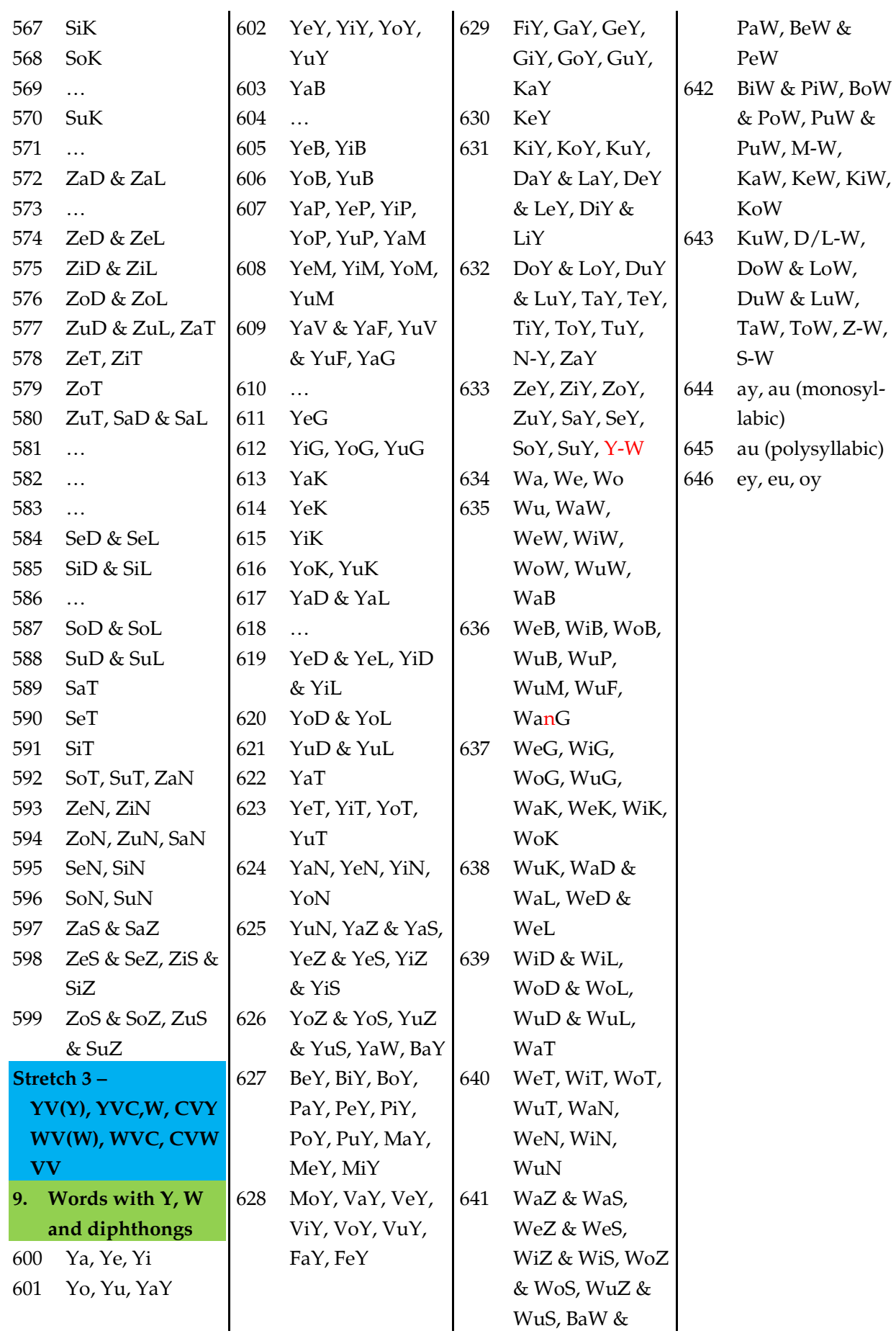


http://lexikos.journals.ac.za

The Lexique kikongo-français by Charles Polis (1938)

Addendum 2: $\quad$ Sample pages from Part II of the Lexique kikongo-français by Charles Polis (1938) [cluster ZaZ; Part II, pp. 127-128]

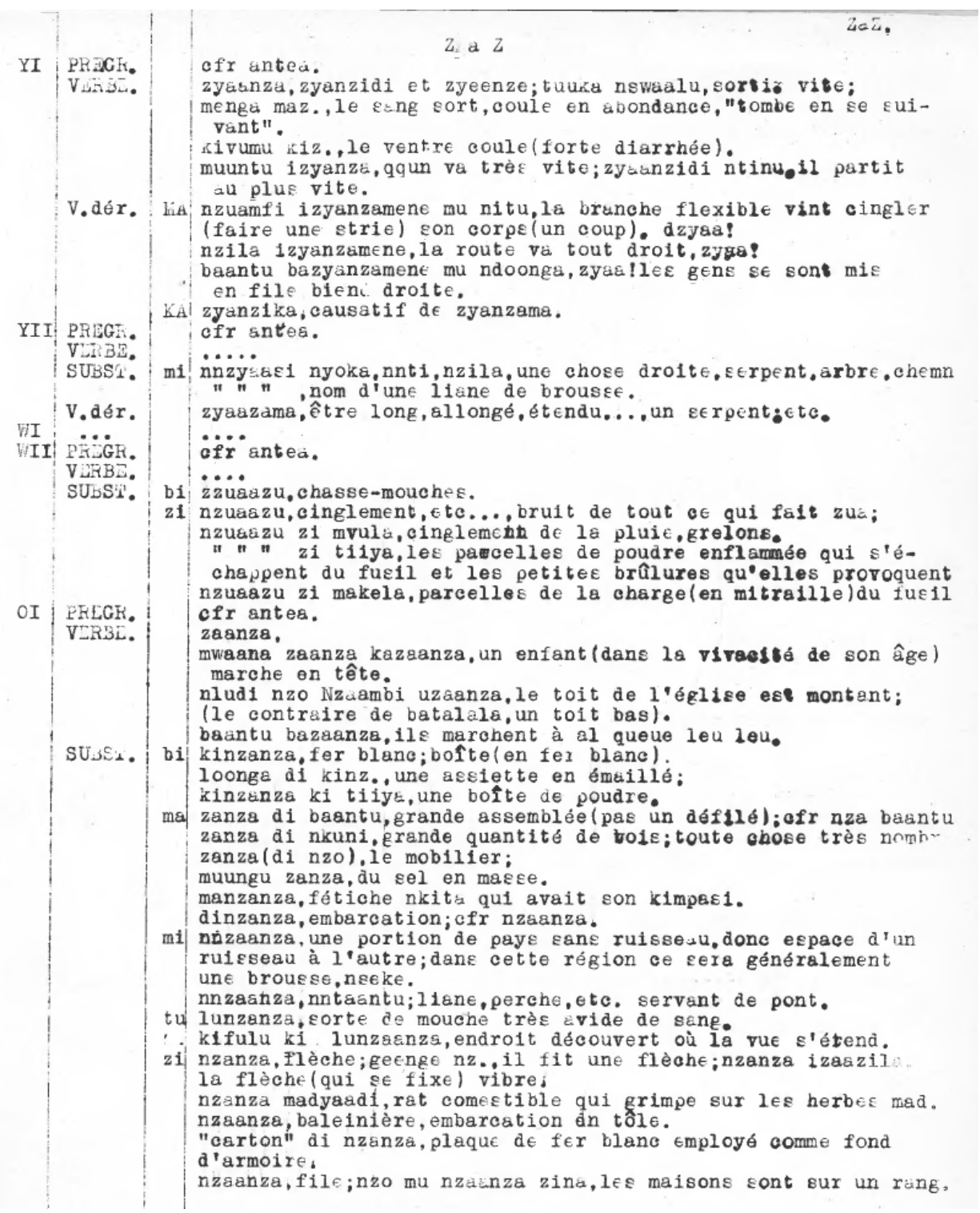


( $Z a Z$ continued, and beginning of $Z e Z$ )

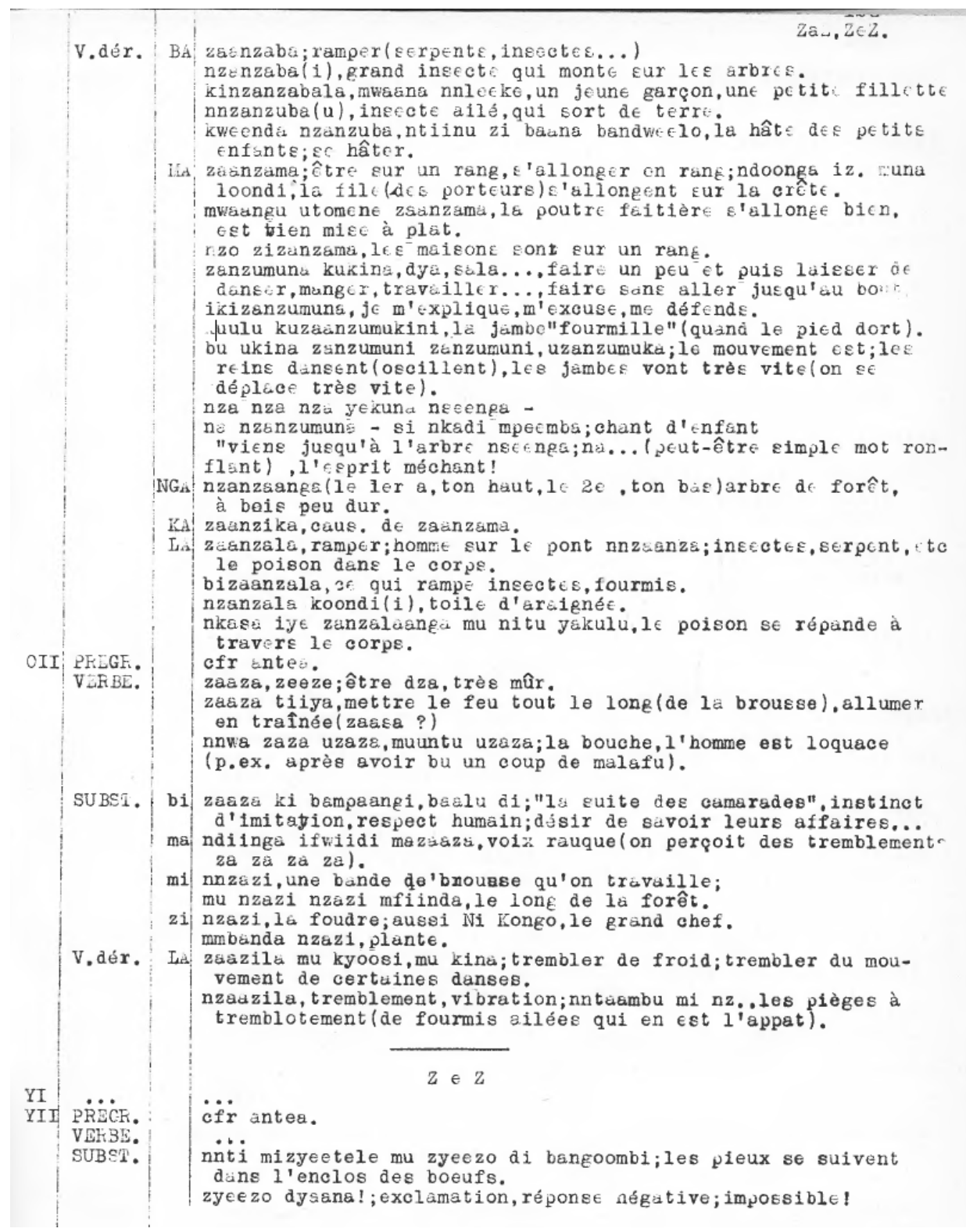


Addendum 3: $\quad$ Sample page from Part I of the Lexique kikongo-français by Charles Polis (1938) [clusters $\mathbf{N e}, \mathbf{N i}, \mathbf{N o}, \mathbf{N u}, \mathbf{N a u}$, and Nan; Part I, p. 24]

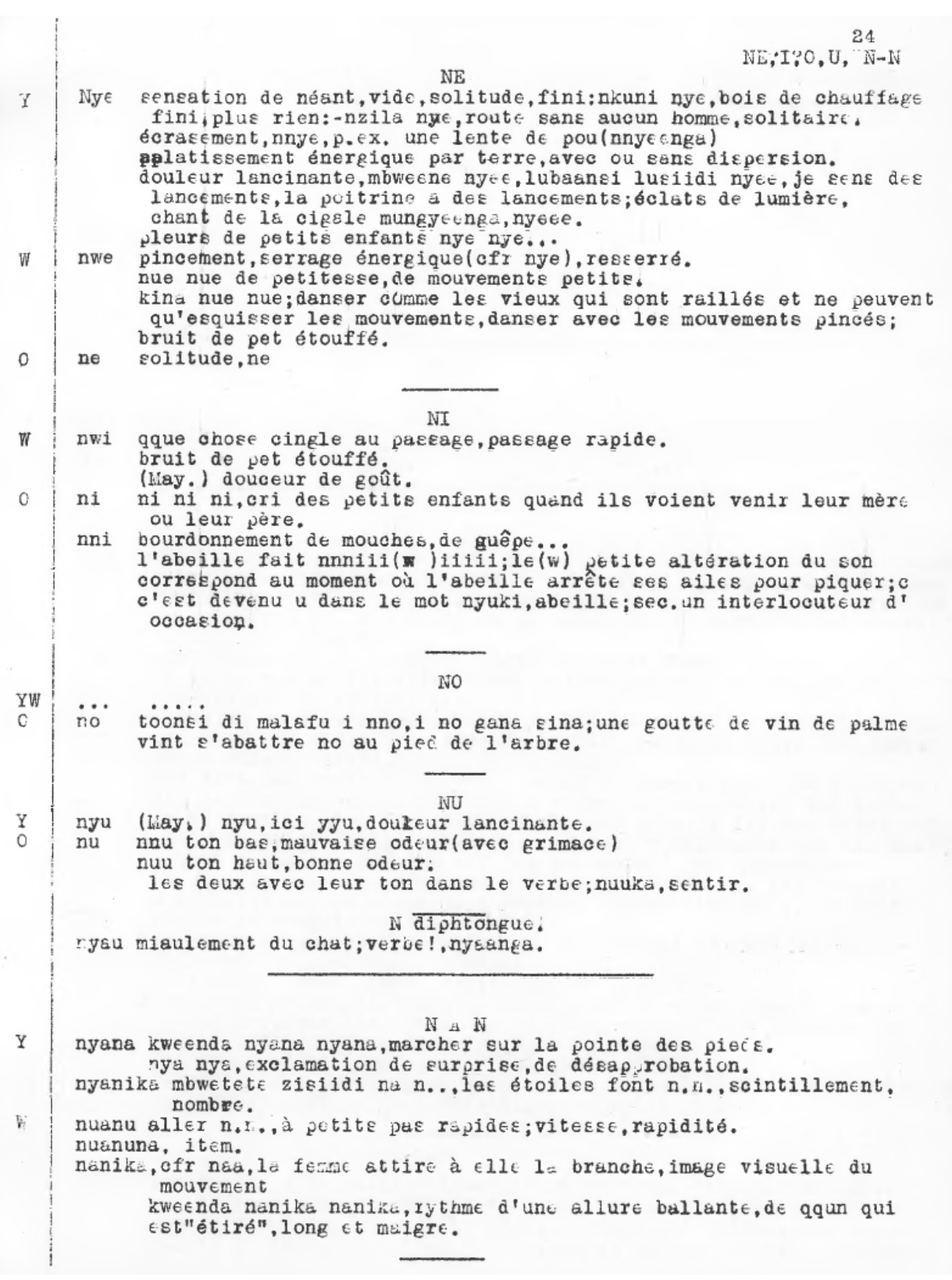


Addendum 4: The cluster Zaz in the Lexique kikongo-français by Charles Polis (1938) [Part I, p. 26]

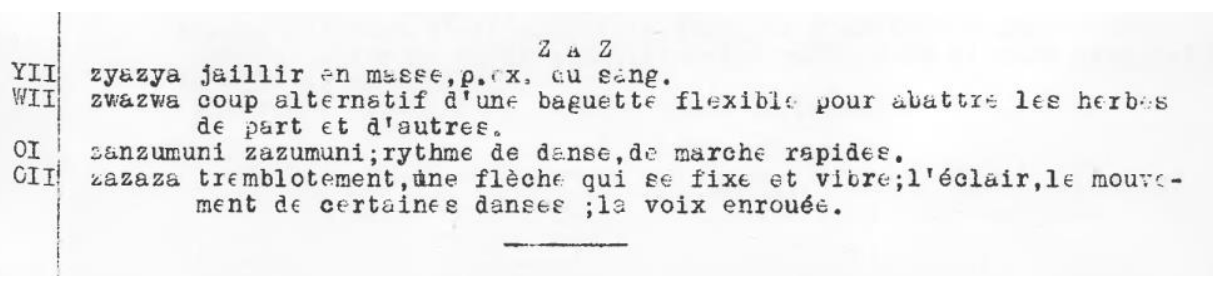

Addendum 5: $\quad$ Data for Test 1: Polis (1938) vs. Butaye (1909) [with for Butaye: $\|=$ main word; ${ }^{*}=$ dialectal form; grey $=$ the form, the meaning, or both are only approximately that/those of Polis; all translations into English are ours]

\begin{tabular}{|c|c|c|c|c|}
\hline \multicolumn{3}{|l|}{ POLIS } & \multicolumn{2}{|l|}{ BUTAYE } \\
\hline Part, p. & Item & English translation & Lemma sign & English translation \\
\hline $\mathrm{I}, 6$ & pyu & pitch-black, very dirty & $\|$ pilu, piu & black, blue \\
\hline I, 16 & kyu & $\begin{array}{l}\text { sound of throat movement } \\
\text { when swallowing }\end{array}$ & - & - \\
\hline I, 26 & $z w e$ & of thorn that enters & - & - \\
\hline $\mathrm{I}, 36$ & myaka & $\begin{array}{l}\text { sparkling, bright like var- } \\
\text { nish }\end{array}$ & miaka & itching \\
\hline I, 46 & kilaa & together! & - & - \\
\hline I, 56 & $z u b u$ & of intelligence; of vigilance & - & - \\
\hline I, 66 & yololo & $\begin{array}{l}\text { of being soaked, of being } \\
\text { drenched }\end{array}$ & - & - \\
\hline II, 9 & kibabu & $\begin{array}{l}\text { usa } \sim=\text { he puts his zeal in } \\
\ldots\end{array}$ & - & - \\
\hline II, 19 & booba & to beat & $b u b a$ & to beat \\
\hline $\begin{array}{l}\text { II, } \\
28 \text { bis }\end{array}$ & -papumuka & to beat (the wings) heavily & pápumúka & to flutter about \\
\hline II, 38 & $\begin{array}{l}\text {-vwiidi } \mathrm{Mb} ., \\
\text {-wiidi Kis. }\end{array}$ & be finished & $\begin{array}{l}{ }^{*} u w a, v w a \\
\text { B.K. (-widi) }\end{array}$ & be completed \\
\hline II, 48 & mfyaafi & armpit & $\begin{array}{c}\text { mfimfiáfi } \mathcal{E} \\
\text { nsimfiafi }\end{array}$ & armpit \\
\hline II, 58 & ngoongi & $\begin{array}{l}\text { internode (of bamboo, } \\
\text { fingers, etc.) }\end{array}$ & $\begin{array}{l}\text { ngongi, } \\
\text { ngonge }\end{array}$ & $\begin{array}{l}\text {... part of a reed between } \\
\text { the nodes }\end{array}$ \\
\hline II, 68 & $k a k a$ & to close & $\| k a k a$ & to obstruct; to close; to hit \\
\hline II, 78 & nnkookolo & song & $\begin{array}{c}\| \text { kékila } \mathcal{E} \\
\text { kokila }\end{array}$ & $\begin{array}{l}\text { to cackle, to sing like } \\
\text { cocks \& to sing (said of } \\
\text { a cock) }\end{array}$ \\
\hline
\end{tabular}




\begin{tabular}{|c|c|c|c|c|}
\hline II, 88 & daada & to beat & ${ }^{*}$ dada & to die a sudden death \\
\hline II, 98 & nnledi & educators & - & - \\
\hline II, 108 & $t a$ & $?$ & $t a$ & [various] \\
\hline II, 118 & ntuuta & quarrel & - & - \\
\hline II, 128 & zaanzaba & to crawl, to slither & ||zánzala & $\begin{array}{l}\text { to crawl, to walk like } \\
\text { insects }\end{array}$ \\
\hline II, 138 & $\begin{array}{l}\text { nsyaasi, } \\
\text { ntsyaasi }\end{array}$ & noise of a small thing & - & - \\
\hline II, 148 & bama & $\begin{array}{l}\text { do quickly (and badly); } b \text {. } \\
\text { nnsiinga = make a bad } \\
\text { knot }\end{array}$ & bama & $\begin{array}{l}\text { to shout; to tighten a knot } \\
\text { (babamini nsinga }=\text { they } \\
\text { have tightened the knot) }\end{array}$ \\
\hline II, 158 & biinga & to call, to summon & \|binga & to go and meet \\
\hline II, 168 & -bokila & to proclaim (cf. p. 75 ) & \|bókila & to call after \\
\hline II, 178 & baanda & to hit & $\|$ banda & to hit \\
\hline II, 188 & mbila & call & $\|$ mbila & call \\
\hline II, 198 & -bweetama & to crush & $\|$ bweta & to crush \\
\hline II, 208 & kimpodi & return obligation & mpodi & credit \\
\hline II, 218 & baasa & to cut, to split, to tear & $\| b a s a$ & to split, make jump \\
\hline II, 228 & maanga & $\begin{array}{l}\text { fetish to discover the magi- } \\
\text { cal cause of an illness; } \\
\text { charm to indicate the } \\
\text { guilty person }\end{array}$ & manga & $\begin{array}{l}\text { charm to uncover the } \\
\text { guilty person }\end{array}$ \\
\hline II, 238 & mweena & for 'to see' & muene & preterite of 'mona' \\
\hline II, 248 & mfubu & $\begin{array}{l}\text { makeenge ma } \sim \text { kind of } \\
\text { pandanus with which } \\
\text { mats are made }\end{array}$ & fubu & $\begin{array}{l}\text { soft stem of the sugar } \\
\text { cane, tender part of the } \\
\text { palm leaf; old basket }\end{array}$ \\
\hline II, 258 & mmfyaangu & $\begin{array}{l}\text { the tissues close to the } \\
\text { waist, the kidneys }\end{array}$ & mfiangu & $\begin{array}{l}\text { bundle of muscles in the } \\
\text { back, from top to bottom }\end{array}$ \\
\hline II, 268 & vidika & $\begin{array}{l}\text { to say something in a } \\
\text { round-about way }\end{array}$ & - & - \\
\hline II, 278 & fulukidi & regained one's senses & $\begin{array}{r}\| f u ́ l u k a \\
\quad \text { (-kidi) }\end{array}$ & $\begin{array}{l}\text { be full; dial. to come back } \\
\text { to life }\end{array}$ \\
\hline II, 288 & mmfunu & utility & mfunu & utility \\
\hline II, 298 & -kwabama & to hit while passing & - & - \\
\hline II, 308 & kuumbidi & opened the mouth & $\begin{array}{r}\| \text { kumba } \\
\text { (-bidi) }\end{array}$ & $\begin{array}{l}\text { to murmur, to make } \\
\text { noise }\end{array}$ \\
\hline II, 318 & kuma & to put on & kuma & to erect, to place, to fix \\
\hline II, 328 & keenge & $\begin{array}{l}\sim \text { kyaafu }=\text { to make a } \\
\text { bridge }\end{array}$ & $\begin{array}{l}\| \text { kanga } \\
\text { (kenge, } \\
\text { kangidi) }\end{array}$ & $\begin{array}{l}\text { to link up, to attach, to } \\
\text { close, to bandage, to } \\
\text { conclude }\end{array}$ \\
\hline II, 338 & $\begin{array}{l}\text { gyyodi } \\
\text { gyyodi }\end{array}$ & bush herb & kiodi-kiodi & $\begin{array}{l}\text { herb that grows on stony } \\
\text { terrain }\end{array}$ \\
\hline II, 348 & -kaandama & be prohibited & kandama & be withheld \\
\hline II, 358 & kedingiinza & $\begin{array}{l}\text { to pound in small double } \\
\text { beats (of the heart) }\end{array}$ & - & - \\
\hline
\end{tabular}




\begin{tabular}{|c|c|c|c|c|}
\hline II, 368 & kunduba & to move unwieldly & - & - \\
\hline II, 378 & kitumuna & $\begin{array}{l}\text { to make someone change } \\
\text { their mind }\end{array}$ & kítumuna & $\begin{array}{l}\text { to change radically, to } \\
\text { bribe, to seduce }\end{array}$ \\
\hline II, 388 & kena & to discover & * gena & to curl up \\
\hline II, 398 & kasu & $\begin{array}{l}\text { ring to keep something } \\
\text { open }\end{array}$ & - & - \\
\hline II, 408 & laamba & to knead & $\| l a m b a$ & $\begin{array}{l}\text { to cook, to steam/braise; } \\
\text { to prepare food }\end{array}$ \\
\hline II, 418 & $\begin{array}{l}\text {-leерата, } \\
\text { leempama? }\end{array}$ & $\begin{array}{l}\text { to be lying in wait, glued } \\
\text { to the floor }\end{array}$ & - & - \\
\hline II, 428 & tuumba & $\begin{array}{l}\text { to impose, to dedicate, to } \\
\text { install }\end{array}$ & $\| t u m b a$ & $\begin{array}{l}\text { to initiate, to confer, to } \\
\text { dedicate }\end{array}$ \\
\hline II, 438 & bundyaafu & gluttony, greed & - & - \\
\hline II, 448 & dingutuna & to cut off a big piece & - & - \\
\hline II, 458 & -looka & to become darker (of fruit) & ||lóka & to become dry \\
\hline II, 468 & taki & black & - & - \\
\hline II, 478 & ntwaadi & $\begin{array}{l}\text { possessed jointly (by two } \\
\text { or more) }\end{array}$ & $\| n t w a d i$ & association; in common \\
\hline II, 488 & dyaana & to make a loud noise & - & - \\
\hline II, 498 & nyama & animal, meat [recent word] & - & - \\
\hline II, 508 & nyuunguta & $\begin{array}{l}\text { confusion of a happy } \\
\text { crowd [sic] }\end{array}$ & * niunguta & $\begin{array}{l}\text { to delight, to dance out } \\
\text { of happiness }\end{array}$ \\
\hline II, 518 & $\begin{array}{l}\text { manyaanza- } \\
\text { nyaanza }\end{array}$ & mist, droplets of rain & $\begin{array}{l}\text { maniánga- } \\
\text { nianga }\end{array}$ & $\begin{array}{l}\text { a few drops of rain, light } \\
\text { and passing rain }\end{array}$ \\
\hline II, 527 & nsaamba & $\begin{array}{l}\text { palm wine drawn from the } \\
\text { male flower of this tree }\end{array}$ & nsamba & palm wine \\
\hline II, 537 & -zoomene & be ripe & zoma (-mene) & $\begin{array}{l}\text { to be yellow or soft like a } \\
\text { ripe fruit }\end{array}$ \\
\hline II, 547 & zyoonguna & to twist, to pull out & zonguna & to prick \\
\hline II, 557 & -swengila & to hurry, to hasten & - & - \\
\hline II, 567 & swiika & $\begin{array}{l}\text { to gobble up (in large } \\
\text { quantities) }\end{array}$ & - & - \\
\hline II, 577 & kinzola & snobbery, vanity & - & - \\
\hline II, 587 & nsila & strip & $\|$ nsila & line, vein, groove \\
\hline II, 597 & masuni & canine teeth & $\begin{array}{l}\text { nsunda, } \\
\text { nsundi }\end{array}$ & boar tusk, canine tooth \\
\hline II, 607 & mayùba & $\begin{array}{l}\text { old word for mantusi }= \\
\text { 'meat maggots' }\end{array}$ & - & - \\
\hline II, 617 & $\begin{array}{l}\text { dyukusu, } \\
\text { yukusu }\end{array}$ & to have eaten one's fill & - & - \\
\hline II, 627 & biiya, biiyidi & to become bad & - & - \\
\hline II, 637 & wengeenge & cartilage & - & - \\
\hline
\end{tabular}


Addendum 6: $\quad$ Data for Test 2: Butaye (1909) vs. Polis (1938) [with for Butaye: $\|$ and no shading = main words; grey = common words; for Polis: green $=$ extensions to the lemma-sign system [sic]; red $=$ errors in the lemma-sign system [sic]; all translations into English are ours]

\begin{tabular}{|c|c|c|c|c|c|}
\hline \multicolumn{4}{|c|}{ BUTAYE } & \multicolumn{2}{|l|}{ POLIS } \\
\hline Page & Lemma sign & POS & English translation & Lemma sign & Part, p. \\
\hline 1 & $\| a k a$ & adv. & yes & $\mathrm{Ka}+\mathrm{O}$, Varia & II, 63 \\
\hline 2 & aritmetika & n. & mathematics & - & - \\
\hline 3 & $\| b a b a$ & n. cl. 5 & $\begin{array}{l}\text { person who is mute } \\
\text { or stutters }\end{array}$ & $\begin{array}{l}\text { BaB + OII, SUBST., } \\
\text { bi }\end{array}$ & II, 8 \\
\hline 4 & bákila & v. rel. & to take for & $\begin{array}{l}\text { BaK + OII, V.DER., } \\
\text { iLA }\end{array}$ & II, 163 \\
\hline 5 & \|bámbuka & v. m. & be reminded & $\begin{array}{l}\text { BaB + OI, V.DER., } \\
\text { KA [as baambuka] }\end{array}$ & II, 6 \\
\hline 6 & bángamísa & v. caus. & $\begin{array}{l}\text { to cause an } \\
\text { oppressed state }\end{array}$ & - & - \\
\hline 7 & $\| b a u$ & $\begin{array}{l}\text { pron. \& } \\
\text { adj.cl. } 2\end{array}$ & they; their & $a u+B,--$ & II, 644 \\
\hline 8 & bémbama & v. i. & be bent, folded & $\begin{array}{l}\text { BeB + OI, V. DER., } \\
\text { MA }\end{array}$ & II, 13 \\
\hline 9 & $\|$ beto, betu & $\begin{array}{l}\text { pron. \& } \\
\text { adj. cl. } 2\end{array}$ & we; our & - & $\mathrm{Y}$ [as beeto] \\
\hline 10 & bikáku & n. cl. 8 & congestion & $\begin{array}{l}\text { KaK + OII, SUBST., } \\
\text { bi }\end{array}$ & II, 68 \\
\hline 11 & \|bindama & v. m. & be closed & $\begin{array}{l}\text { BiD + OI, V.DER., } \\
\text { aMA [as biindama] }\end{array}$ & II, 186 \\
\hline 12 & bítana & v. rec. & to catch one another & - & - \\
\hline 13 & \|bôla & n. cl. 5 & onion & $\begin{array}{l}\text { BoL + OII, SUBST., } \\
\text { ma [as boola] }\end{array}$ & II, 190 \\
\hline 14 & $\begin{array}{l}\text { bonsikila, } \\
\text { bonsukila }\end{array}$ & v. i. & to insist & $\begin{array}{l}\text { BoZ \& BoS + WII, } \\
\text { V.DER., iKA }\end{array}$ & II, 221 \\
\hline 15 & \|buau & adv. & like this & $\begin{array}{l}\text { au }+\mathbf{B}, \mathbf{b u} \text { [as bwau; } \\
\text { but not with main } \\
\text { meaning] }\end{array}$ & II, 644 \\
\hline 16 & buingi & $\begin{array}{l}\text { adj. \& } \\
\text { adv. }\end{array}$ & a lot & - & $\begin{array}{l}\mathrm{Y} \text { [as } \\
\text { bubwiingi] }\end{array}$ \\
\hline 17 & ||búkumúka & v. m. & $\begin{array}{l}\text { be destroyed; be } \\
\text { overturned }\end{array}$ & $\begin{array}{l}\text { BuK + OII, V.DER., } \\
\text { uMA }\end{array}$ & II, 170 \\
\hline 18 & bumbangu & n. cl. 14 & craft knowledge & - & - \\
\hline 19 & \|buna & v. tr. & to skin & BuN + O, VERBE & II, 215 \\
\hline 20 & bundumba & n. cl. 14 & standing of a girl & - & - \\
\hline 21 & $\| b u s i$ & n. cl. 5 & wad of a gun & $\begin{array}{l}\text { BuZ \& BuS + OII, } \\
\text { SUBST. [as buusi] }\end{array}$ & II, 222 \\
\hline
\end{tabular}




\begin{tabular}{|c|c|c|c|c|c|}
\hline 22 & buyúmbulu & n. cl. 14 & big stupidity & $\begin{array}{l}\text { Yub + I, } \mathbf{5} \text { [as } \\
\text { yuumbulu] }\end{array}$ & $\mathrm{I}, 64$ \\
\hline 23 & $\|$ dâka & v. i. & $\begin{array}{l}\text { to split/crack; to } \\
\text { shatter }\end{array}$ & $\begin{array}{l}\text { DaK \& LaK + OII, } \\
\text { VERBE }\end{array}$ & II, 451 \\
\hline 24 & diadia & n. cl. 5 & tall bush & - & $\mathrm{Y}$ [as dyadya] \\
\hline 25 & $\|$ diata & v. i. & to walk & $\begin{array}{l}\text { DaT \& LaT + YII, } \\
\text { VERBE [as dyaata] }\end{array}$ & II, 474 \\
\hline 26 & diéngasa & v. tr. & to make turn & $\begin{array}{l}\text { DeG \& LeG + YI, } \\
\text { V.DER., aSA [as } \\
\text { dyengasa] }\end{array}$ & II, 443 \\
\hline 27 & $\|$ dila & v. i. & to cry/weep & $\mathrm{DiL}+\mathrm{O}, \mathrm{VERBE}$ & II, 99 \\
\hline 28 & dinkúndi(a) & n. cl. 5 & $\begin{array}{l}\text { sp. of climbing } \\
\text { plant }\end{array}$ & - & - \\
\hline 29 & ||dóngumúka & v. m. & to emerge & - & - \\
\hline 30 & $e$ & $\begin{array}{l}\text { quest. } \\
\text { part.; } \\
\text { affirm. } \\
\text { part. }\end{array}$ & $? ; !$ & - & - \\
\hline 31 & $\| f i-$ & $\begin{array}{l}\text { dim. } \\
\text { pref. }\end{array}$ & $\begin{array}{l}\text { a little bit, a small } \\
\text { amount }\end{array}$ & Fi + O, SUBST., FI & II, 47 \\
\hline 32 & fídila & v. rel. & to lead to & $\begin{array}{l}\text { FiD \& FiL + OII, } \\
\text { V.DER., iLA }\end{array}$ & II, 275 \\
\hline 33 & $\|$ fioti & adv. & a little & $\begin{array}{l}\text { FoT + YII, VARIA [as } \\
\text { fyote] }\end{array}$ & II, 282 \\
\hline 34 & fókuka & v. m. & $\begin{array}{l}\text { be folded; be multi- } \\
\text { plied }\end{array}$ & $\begin{array}{l}\text { FoK + OII, V.DER., } \\
\text { uKA }\end{array}$ & II, 262 \\
\hline 35 & $\|$ fula & v. tr. & $\begin{array}{l}\text { to conclude; to } \\
\text { forge; to blow }\end{array}$ & $\begin{array}{l}\text { FuD \& FuL + OII, } \\
\text { VERBE [as fula and } \\
\text { fuula] }\end{array}$ & II, 276 \\
\hline 36 & fúmbama & v. m. & be curved & $\begin{array}{l}\text { FuB + OI, V.DER., } \\
\text { aMA [as -fuubama; a } \\
\text { typo] }\end{array}$ & II, 247 \\
\hline 37 & \|fúnguna & v. tr. & to confess & $\begin{array}{l}\text { FuG + OI, V.DER., } \\
\text { uNA }\end{array}$ & II, 260 \\
\hline 38 & futana & v. tr. & be vexed & - & - \\
\hline 39 & $\|$ fwanasa & v. caus. & to make equal & $\begin{array}{l}\text { FaN + W, V.DER., } \\
\text { aSA }\end{array}$ & II, 286 \\
\hline 40 & $g a$ & v. i. & to produce (fruit) & $\mathrm{Ga}+\mathrm{O}, \mathrm{VERBE}$ & II, 51 \\
\hline 41 & $\begin{array}{l}\| \text { gala-nti, gadi- } \\
n t i\end{array}$ & n. cl. 7 & carpenter & - & - \\
\hline 42 & gangama & v. m. & to be in order & $\begin{array}{l}\text { GaG + OI, V.DER., } \\
\text { MA }\end{array}$ & II, 54 \\
\hline 43 & || gedila & v. rel. & be clean/pure & $\begin{array}{l}\text { GeD \& GeL + OII, } \\
\text { V.DER., iLA }\end{array}$ & II, 337 \\
\hline
\end{tabular}


http://lexikos.journals.ac.za

The Lexique kikongo-français by Charles Polis (1938)

\begin{tabular}{|c|c|c|c|c|c|}
\hline 44 & $\begin{array}{l}\text { gelele, gelele- } \\
\text { gelele }\end{array}$ & inv. & purity & Gel & I, 41 \\
\hline 45 & $\| g o, g o g o$ & $\begin{array}{l}\text { adv.; } \\
\text { conj. }\end{array}$ & $\begin{array}{l}\text { here/there; if, } \\
\text { when; or }\end{array}$ & - & - \\
\hline 46 & gólakána & v. poss. & $\begin{array}{l}\text { be able to be pulled; } \\
\text { to slip }\end{array}$ & $\begin{array}{l}\text { GoL + OII, V.DER., } \\
\text { aKA }\end{array}$ & II, 339 \\
\hline 47 & \|gongi & n. cl. 5 & ball (of food) & $\begin{array}{l}\text { GoG + O, SUBST., } \\
\text { ma [as goongi] }\end{array}$ & II, 57 \\
\hline 48 & guga & n. cl. 5 & $\begin{array}{l}\text { space between two } \\
\text { objects }\end{array}$ & - & - \\
\hline 49 & \|gulusa & v. caus. & to save & $\begin{array}{l}\text { GuD + OII, V.DER., } \\
\text { uSA }\end{array}$ & II, 341 \\
\hline 50 & Iezu Kristu & n. & Jesus Christ & - & - \\
\hline 51 & $\| k a b a$ & v. tr. & to give, to share & KaB + OII, VERBE & II, 300 \\
\hline 52 & kakala & v. i. & $\begin{array}{l}\text { to slip, to } \\
\text { worm/inch }\end{array}$ & - & - \\
\hline 53 & \|kádila & v. rel. & $\begin{array}{l}\text { to stay for; to be } \\
\text { with }\end{array}$ & $\begin{array}{l}\text { KaD \& KaL + OII, } \\
\text { V.DER., iLA }\end{array}$ & II, 352 \\
\hline 54 & kambalala & v. i. & $\begin{array}{l}\text { be at fault; to over- } \\
\text { shoot }\end{array}$ & $\begin{array}{l}\text { KaB + OI, V.DER., } \\
\text { aLA }\end{array}$ & II, 299 \\
\hline 55 & \|kándikíla & v. tr. & to prohibit & - & $\begin{array}{l}\text { Y [at kadila, } \\
\text { p. II, 352] }\end{array}$ \\
\hline 56 & kani & adv. & not yet; not; or & $\mathrm{KaN}+\mathrm{O}$, VARIA & II, 385 \\
\hline 57 & $\| k a t i-k a t i$ & adv. & in the middle & $\begin{array}{l}\text { KaT + OII, Varia [as } \\
\text { kati kati] }\end{array}$ & II, 373 \\
\hline 58 & kekumuna & v. tr. & be thirsty & $\begin{array}{l}\text { KeK + OII, V.DER., } \\
\text { uMA [as 'to clear } \\
\text { one's throat'] }\end{array}$ & II, 72 \\
\hline 59 & \|kenga & v. i. & $\begin{array}{l}\text { to stop doing, to } \\
\text { renounce }\end{array}$ & $\begin{array}{l}\text { KeG + OI, VERBE [as } \\
\text { keenga] }\end{array}$ & II, 330 \\
\hline 60 & kétalála & v. i. & to hold on; to insist & $\begin{array}{l}\text { KeT + OII, V.DER., } \\
\text { aLA }\end{array}$ & II, 376 \\
\hline 61 & $\| k i a, k i y a$ & v. i. & to clear up & $\begin{array}{l}\text { Ka + Y, VERBE [as } \\
k y a]\end{array}$ & II, 61 \\
\hline 62 & kiatumuna & v. tr. & $\begin{array}{l}\text { to place a crowd in } \\
\text { rows }\end{array}$ & - & - \\
\hline 63 & ||kibota & n. cl. 7 & club, bludgeon & - & - \\
\hline 64 & kidíla & n. cl. 7 & stock of goods & $\mathrm{DiL}+\mathrm{O}$, SUBST., bi & II, 99 \\
\hline 65 & $\| k i f u$ & n. cl. 7 & $\begin{array}{l}\text { quality, character; } \\
\text { vice, error }\end{array}$ & Fu + O, SUBST., bi & II, 47 \\
\hline 66 & kigana & v. refl. & to sacrifice oneself & - & - \\
\hline 67 & \|kikálulu & n. cl. 7 & residence; character & $\begin{array}{l}\text { KaD \& KaL + OII, } \\
\text { V.DER., uLA }\end{array}$ & II, 352 \\
\hline 68 & kikongi & n. cl. 7 & small duck & $\begin{array}{l}\text { KoG + OI, SUBST., } \\
\text { bi }\end{array}$ & II, 332 \\
\hline
\end{tabular}


124 Gilles-Maurice de Schryver

\begin{tabular}{|c|c|c|c|c|c|}
\hline 69 & $\| k i k w a$ & n. cl. 7 & potato; big tuber & Ka + W, SUBST., bi & II, 61 \\
\hline 70 & kileso ki muini & n. cl. 7 & $\begin{array}{l}\text { dazzling ray of } \\
\text { light }\end{array}$ & - & - \\
\hline 71 & $\|$ kimbefo & n. cl. 7 & illness & $\begin{array}{l}\text { BeF + OII, SUBST., } \\
\text { bi [as kimbeefo] }\end{array}$ & II, 152 \\
\hline 72 & kimbundu & adv. & as a whole & $\begin{array}{l}\text { BuD + OI, SUBST., } \\
\text { bi [as (ki)buundu] }\end{array}$ & II, 191 \\
\hline 73 & \|kimosi & n. cl. 7 & unity & $\begin{array}{l}\text { MoZ \& MoS + OI, } \\
\text { VARIA }\end{array}$ & II, 241 \\
\hline 74 & $\begin{array}{l}\text { kimpólokósu, } \\
\text { kimpolongoso }\end{array}$ & n. cl. 7 & cavity & $\begin{array}{l}\text { PoL + OII, V.DER., } \\
\text { NGA }\end{array}$ & II, 208 \\
\hline 75 & $\|$ kindiku & n. cl. 7 & friendship & $\begin{array}{l}\text { DiK + OII, SUBST., } \\
\text { bi }\end{array}$ & II, 456 \\
\hline 76 & kingándi & n. cl. 7 & whatchamacallit & GaD + OI, VARIA & II, 335 \\
\hline 77 & \|kinkála & n. cl. 7 & kick & $\begin{array}{l}\text { KaD \& KaL + OII, } \\
\text { SUBST., bi }\end{array}$ & II, 350 \\
\hline 78 & kinkutula & adj. & that opens by itself & - & $\begin{array}{l}\text { - [but verb } \\
\text { is in, p. II, } \\
\text { 382] }\end{array}$ \\
\hline 79 & $\|$ kintete & $\begin{array}{l}\text { n. cl. } 7 \\
\text { adv. }\end{array}$ & priority; first & - & Y [as ntete] \\
\hline 80 & kintwema & n. cl. 7 & breathlessness & - & - \\
\hline 81 & $\|$ kiôlólo & n. cl. 7 & cry; applause & $\begin{array}{l}\text { KoD \& KoL + YII, } \\
\text { V.DER., uLA [as } \\
\text { kyololo] }\end{array}$ & II, 361 \\
\hline 82 & kisania & n. cl. 7 & $\begin{array}{l}\text { small tree with } \\
\text { beautiful white } \\
\text { flowers and good } \\
\text { wood }\end{array}$ & SaN + O, SUBST., bi & II, 594 \\
\hline 83 & $\|$ kisina & n. cl. 7 & origin & $\mathrm{SiN}+\mathrm{O}, \mathrm{SUBST} ., \mathrm{bi}$ & II, 595 \\
\hline 84 & kiswamu & n. cl. 7 & hiding-place & $\begin{array}{l}\text { SaM + W, V.DER., } \\
\text { uNA [as kiswaamunu] }\end{array}$ & II, 538 \\
\hline 85 & $\|$ kiteso & n. cl. 7 & measure, model & $\begin{array}{l}\text { TeZ \& TeS + OII, } \\
\text { SUBST., bi [as kiteeso] }\end{array}$ & II, 495 \\
\hline 86 & kítumúka & v. m. & $\begin{array}{l}\text { to undergo a radical } \\
\text { change }\end{array}$ & $\begin{array}{l}\text { KiT + OII, V.DER., } \\
\text { uMA }\end{array}$ & II, 378 \\
\hline 87 & \|kivúmu & n. cl. 7 & stomach & VuM + O, SUBST., bi & II, 249 \\
\hline 88 & kiyaka & n. cl. 15 & assumption & - & - \\
\hline 89 & \|kizanu, kizalu & n. cl. 7 & insubordination & - & $\begin{array}{l}\text { — [but verb } \\
\text { is in, p. II, } \\
\text { 593] }\end{array}$ \\
\hline 90 & kobe & n. cl. 5 & strong man & - & - \\
\hline 91 & $\|$ kodila & v. rel. & $\begin{array}{l}\text { to pull for; be } \\
\text { strong at }\end{array}$ & $\begin{array}{l}\text { KoD \& KoL + OII, } \\
\text { V.DER., iLA }\end{array}$ & II, 366 \\
\hline
\end{tabular}


http://lexikos.journals.ac.za

The Lexique kikongo-français by Charles Polis (1938)

\begin{tabular}{|c|c|c|c|c|c|}
\hline 92 & kómakána & v. i. & $\begin{array}{l}\text { be additionally } \\
\text { added }\end{array}$ & - & - \\
\hline 93 & \|kondisa & v. tr. & $\begin{array}{l}\text { to make chase; to } \\
\text { subtract }\end{array}$ & $\begin{array}{l}\text { KoD \& KoL + OI, } \\
\text { V.DER., iSA [as } \\
\text {-koondisa] }\end{array}$ & II, 363 \\
\hline 94 & konko & n. cl. 7 & angle & $\begin{array}{l}\text { KoK + OI, SUBST., } \\
\text { bi [as ikoonko] }\end{array}$ & II, 75 \\
\hline 95 & $\| k u, k u k u, k u n a$ & $\begin{array}{l}\text { adv.; } \\
\text { dem.; } \\
\text { prep. }\end{array}$ & $\begin{array}{l}\text { here/there; } \\
\text { this/that; by, for, } \\
\text { towards }\end{array}$ & $\begin{array}{l}\text { Ku + O, VARIA; } \\
\text { KuK + OII, VARIA }\end{array}$ & II, 65; II, 80 \\
\hline 96 & kúbakána & v. poss. & to be able to err & $\begin{array}{l}\text { KuB + OII, V.DER., } \\
\text { aKA }\end{array}$ & II, 310 \\
\hline 97 & \|kúfama & v. m. & be short & $\begin{array}{l}\text { KuF + OII, V.DER., } \\
\text { aMA }\end{array}$ & II, 323 \\
\hline 98 & kukusu & adv. & $\begin{array}{l}\text { kituka } \sim=\text { be full of } \\
\text { mud }\end{array}$ & - & - \\
\hline 99 & ||kúlumúka & v. m. & to go down & $\begin{array}{l}\text { KuD \& KuL + OII, } \\
\text { V.DER., uMA }\end{array}$ & II, 370 \\
\hline 100 & kúmbalála & v. i. & to be abundant & $\begin{array}{l}\text { KuB + OI, V.DER., } \\
\text { aLA }\end{array}$ & II, 309 \\
\hline 101 & \|kundá & adv. & far, high, deep & $\begin{array}{l}\text { KuD \& KuL + OI, } \\
\text { SUBST., mi [as n. } \\
\text { nnkuunda] }\end{array}$ & II, 367 \\
\hline 102 & kúnkúfi & adv. & $\begin{array}{l}\text { very/too close, too } \\
\text { short }\end{array}$ & - & - \\
\hline 103 & \|kútuka & v. m. & to undo & $\begin{array}{l}\text { KuT + OII, V.DER., } \\
\text { uKA }\end{array}$ & II, 381 \\
\hline 104 & kwámína & v. rel. & to persevere in & $\begin{array}{l}\text { KaM + W, V.DER., } \\
\text { iNA }\end{array}$ & II, 315 \\
\hline 105 & $\| k w i k a$ & v. tr. & $\begin{array}{l}\text { to switch on, to } \\
\text { arrange }\end{array}$ & $\begin{array}{l}\text { KiK + WII, VERBE } \\
\text { [as kwiika] }\end{array}$ & II, 73 \\
\hline 106 & labidika & v. i. & to launch, to throw & $\begin{array}{l}\text { BaB \& LaB + OII, } \\
\text { V.DER., iLA }\end{array}$ & II, 409 \\
\hline 107 & ||lalánsa & n. cl. 5 & orange (tree) & $\begin{array}{l}\text { LaL + OII, SUBST., } \\
\text { ma [as mlaala] }\end{array}$ & II, 89 \\
\hline 108 & lâmbidíka & v. tr. & to lay on its side & $\begin{array}{l}\text { BaB \& LaB + OI, } \\
\text { V.DER., aLA }\end{array}$ & II, 408 \\
\hline 109 & ||lángidíla & v. rel. & $\begin{array}{l}\text { to watch, to keep an } \\
\text { eye on }\end{array}$ & $\begin{array}{l}\text { DaG \& LaG + OI, } \\
\text { V.DER., iLA }\end{array}$ & II, 442 \\
\hline 110 & laza & n. cl. 5 & empty words & - & - \\
\hline 111 & \|lela & v. i. & be slippery & LeL + OII, VERBE & II, 95 \\
\hline 112 & lembanzau & n. cl. 7 & $\begin{array}{l}\text { wild pomegranate } \\
\text { tree; fetish palm }\end{array}$ & - & - \\
\hline 113 & |lenga & v. i. & $\begin{array}{l}\text { to walk, be on the } \\
\text { way }\end{array}$ & $\begin{array}{l}\text { DeG \& LeG + OI, } \\
\text { VERBE }\end{array}$ & II, 444 \\
\hline
\end{tabular}




\begin{tabular}{|c|c|c|c|c|c|}
\hline 114 & lensi & n. cl. 5 & bitter taste & $\begin{array}{l}\text { DeZ \& DeS \& LeZ \& } \\
\text { LeS + OI, SUBST., } \\
\text { ma }\end{array}$ & II, 491 \\
\hline 115 & \|lolula & v. tr. & to forgive & - & $\begin{array}{l}\text { — [but loluka } \\
\text { 'be pardoned' } \\
\text { is in, p. II, 101] }\end{array}$ \\
\hline 116 & lóngakana & v. i. & $\begin{array}{l}\text { to be prone to } \\
\text { instruction }\end{array}$ & - & $\begin{array}{l}\text { - [but } \\
\text { longuka 'be } \\
\text { instructed' is } \\
\text { in, p. II, 449] }\end{array}$ \\
\hline 117 & \|lotó & n. cl. 11 & spoon & To + O, SUBST., tu & II, 109 \\
\hline 118 & lubasa lu nima & n. cl. 11 & backbone & - & $\begin{array}{l}\text { Y [pp. II, 139; } \\
\text { II, 432; II, 615] }\end{array}$ \\
\hline 119 & \|lufwá & n. cl. 11 & death & $\mathrm{Fa}+\mathrm{W}, \mathrm{SUBST} ., \mathrm{tu}$ & II, 45 \\
\hline 120 & lugambuku & n. cl. 11 & $\begin{array}{l}\text { space, distance; } \\
\text { retreat }\end{array}$ & - & $\begin{array}{l}\text { - [but verb } \\
\text {-gaambuku is } \\
\text { in, p. II, 293] }\end{array}$ \\
\hline 121 & ||lukáya & n. cl. 11 & leaf & $\mathrm{KaY}+\mathrm{O}$, SUBST., tu & II, 630 \\
\hline 122 & lukúba & n. cl. 11 & pillow & $\begin{array}{l}\text { KuB + OII, SUBST., } \\
\text { tu }\end{array}$ & II, 310 \\
\hline 123 & $\| l u m b a$ & v. tr.; v. i. & $\begin{array}{l}\text { to drop violently; to } \\
\text { move forward }\end{array}$ & $\begin{array}{l}\text { DuB \& LuB + OI, } \\
\text { VERBE }\end{array}$ & II, 416 \\
\hline 124 & lumoko & n. cl. 11 & chatter, gossip & $\begin{array}{l}\text { MoK + OII, SUBST., } \\
\text { bi \& ma [as moko \& } \\
\text { mamoko] }\end{array}$ & II, 232 \\
\hline 125 & \|lunga & v. tr.; v. i. & $\begin{array}{l}\text { to keep; be correct, } \\
\text { be perfect }\end{array}$ & $\begin{array}{l}\text { DuG \& LuG + OI, } \\
\text { VERBE }\end{array}$ & II, 450 \\
\hline 126 & lunsamba & n. cl. 11 & edible mushroom & $\begin{array}{l}\text { SaB + OI, SUBST., } \\
\text { bu [as bunsambi] }\end{array}$ & II, 526 \\
\hline 127 & |lusendo & n. cl. 11 & thorn & $\begin{array}{l}\text { SeD \& SeL + OI, } \\
\text { SUBST., tu [as } \\
\text { luseende] }\end{array}$ & II, 584 \\
\hline 128 & lutangu & n. cl. 11 & $\begin{array}{l}\text { reading, enumera- } \\
\text { tion }\end{array}$ & TaG + OI, SUBST., tu & II, 462 \\
\hline 129 & $\| l u z i k u$ & n. cl. 11 & funeral & $\begin{array}{l}\text { ZiK + OII, SUBST., } \\
\text { tu }\end{array}$ & II, 551 \\
\hline 130 & lwákila & v. rel. & to arrive at & - & $\begin{array}{l}\text { - [but base } \\
\text { verb -lwaaka } \\
\text { 'to arrive' is } \\
\text { in, p. II, } 451]\end{array}$ \\
\hline 131 & \|mádia & n. cl. 15 & food & $\begin{array}{l}\text { Da }+ \text { Y, SUBST., bi } \\
\text { [as kindya, kidya] }\end{array}$ & II, 82 \\
\hline 132 & mafubu & n. cl. 6 & $\begin{array}{l}\text { marrow of palm } \\
\text { leaves }\end{array}$ & $\begin{array}{l}\text { FuB + OII, SUBST., } \\
\text { ma }\end{array}$ & II, 247 \\
\hline
\end{tabular}


http://lexikos.journals.ac.za

The Lexique kikongo-français by Charles Polis (1938)

\begin{tabular}{|c|c|c|c|c|c|}
\hline 133 & \|makábu & n. cl. 6 & present, gift & $\begin{array}{l}\text { KaB + WII, SUBST., } \\
\text { ma [as makwaabu] }\end{array}$ & II, 297 \\
\hline 134 & makésa & n. cl. 6 & soldiers, army & $\begin{array}{l}\text { KeS + OII, SUBST., } \\
\text { ma [as kesa] }\end{array}$ & II, 401 \\
\hline 135 & $\|$ makutu & n. cl. 6 & ears & $\begin{array}{l}\text { KuT + OII, SUBST., } \\
(\mathrm{ku})\end{array}$ & II, 381 \\
\hline 136 & maléla & n. cl. 6 & $\begin{array}{l}\text { small pagnes (front } \\
\text { and back) }\end{array}$ & $\begin{array}{l}\text { LeL + OII, SUBST., } \\
\text { ma [as maleela] }\end{array}$ & II, 95 \\
\hline 137 & $\|$ mampa & n. cl. 6 & bread & $\begin{array}{l}\mathbf{P a}+\mathbf{O}, \mathbf{S U B S T} ., \mathbf{m a} \\
\text { [as dimpa] }\end{array}$ & II, 26 \\
\hline 138 & manganana & v. i. & $\begin{array}{l}\text { to hold one's chest } \\
\text { in front }\end{array}$ & $\begin{array}{l}\text { MaG + OI, V.DER., } \\
\text { aNA }\end{array}$ & II, 228 \\
\hline 139 & $\|$ manta, mata & v. & to $c \operatorname{limb}$ & MaT + OII, VERBE & II, 235 \\
\hline 140 & masekwasa & n. cl. 6 & sparrows & $\begin{array}{l}\text { ZoK + OII, V.DER., } \\
\text { aSA [as mazokaasi, } \\
\text { masekwasi] }\end{array}$ & II, 553 \\
\hline 141 & $\|$ maté & n. cl. 6 & saliva, mucus & $\begin{array}{l}\text { Te + O, SUBST., ma } \\
{[\text { as } t e]}\end{array}$ & II, 108 \\
\hline 142 & mavwangi & n. cl. 6 & bushes in a wood & $\begin{array}{l}\text { VaG + WI, SUBST., } \\
\text { ma, i }\end{array}$ & II, 253 \\
\hline 143 & ||mazóno & n. cl. 6 & $\begin{array}{l}\text { yesterday, an } \\
\text { earlier day }\end{array}$ & $\begin{array}{l}\text { ZoN + O, SUBST., } \\
\text { ma [as zono, mazoono] }\end{array}$ & II, 594 \\
\hline 144 & mbamu & n. cl. 9 & $\begin{array}{l}\text { abuser of power, } \\
\text { exploiter }\end{array}$ & $\begin{array}{l}\text { BaM + O, SUBST., zi } \\
\text { [as mbaamu, and } \\
\text { meaning shift] }\end{array}$ & II, 148 \\
\hline 145 & $\| m b a s i, m b a z i$ & n. cl. 7 & $\begin{array}{l}\text { tomorrow, a future } \\
\text { day }\end{array}$ & $\begin{array}{l}\text { BaZ \& BaS + OII, } \\
\text { VARIA }\end{array}$ & II, 218 \\
\hline 146 & $m b e m b a-m b e m b a$ & n. cl. 9 & butterflies & $\begin{array}{l}\text { BeB + OI, SUBST., tu } \\
\text { [as lumbemba mbemba] }\end{array}$ & II, 13 \\
\hline 147 & $\|$ mbeni & n. cl. 9 & enemy & $\begin{array}{l}\text { BeN + O, SUBST., zi } \\
\text { [as mbeeni] }\end{array}$ & II, 214 \\
\hline 148 & mbílama & n. cl. 9 & $\begin{array}{l}\text { abundance, multi- } \\
\text { plication }\end{array}$ & $\begin{array}{l}\text { BiL + OII, V.DER., } \\
\text { aMA [as perfect verb } \\
\text {-bilamene] }\end{array}$ & II, 188 \\
\hline 149 & $\| m b o k o$ & n. cl. 9 & bought peace & $\begin{array}{l}\text { BoK + OII, SUBST., } \\
\text { zi, o }\end{array}$ & II, 167 \\
\hline 150 & $m b o t a$ & n. cl. 9 & hard-wood tree & $\begin{array}{l}\text { BoT + OII, SUBST., } \\
\text { zi }\end{array}$ & II, 201 \\
\hline 151 & $\|$ mbulu-mbulu & n. cl. 9 & $\begin{array}{l}\text { small black fly; } \\
\text { black soldier }\end{array}$ & BuL + SUBST., zi & II, 194 \\
\hline 152 & mbundu & n. cl. 3 & $\begin{array}{l}\text { short grass; big } \\
\text { crowd }\end{array}$ & $\begin{array}{l}\text { BuD + OI, SUBST., } \\
\text { ma, IIu [as buundu] }\end{array}$ & II, 191 \\
\hline 153 & \|lmbweta & n. cl. 9 & ball, sphere & $\begin{array}{l}\text { BeT + WII, SUBST., } \\
\text { zi [as mbweeta] }\end{array}$ & II, 197 \\
\hline
\end{tabular}




\begin{tabular}{|c|c|c|c|c|c|}
\hline 154 & mengi & adj. cl. 6 & a lot & - & - \\
\hline 155 & $\| m f i k u$ & n. cl. 9 & $\begin{array}{l}\text { age of wine; power } \\
\text { of food; low price }\end{array}$ & $\begin{array}{l}\text { FiK + OII, SUBST., } \\
\text { mi \& zi [as mmfiku \& } \\
m f i k u]\end{array}$ & II, 261-2 \\
\hline 156 & mfuki & n. cl. 3 & $\begin{array}{l}\text { small civet; pain } \\
\text { radiance }\end{array}$ & $\begin{array}{l}\text { FuK + OII, SUBST., } \\
\text { mi \& zi }\end{array}$ & II, 263 \\
\hline 157 & $\| m f u n d u$ & $\begin{array}{l}\text { n. cl. } 3 ; \mathrm{n} . \\
\text { cl. } 9\end{array}$ & lawsuit; secret & $\begin{array}{l}\text { FuD \& FuL + OI, } \\
\text { SUBST., mi [as } \\
\text { mmfuundu] }\end{array}$ & II, 275 \\
\hline 158 & $m f w a$ & n. cl. 9 & death & Fa + W, SUBST., zi & II, 45 \\
\hline 159 & $\|$ miáya & n. cl. 4 & yawning & $\begin{array}{l}\text { MaY + WII, SUBST., } \\
\text { mi [as mmwaayi] }\end{array}$ & II, 627 \\
\hline 160 & minuta & n. cl. 3 & minute & - & - \\
\hline 161 & $\|$ mongo & n. cl. 3 & mountain & $\begin{array}{l}\text { MoG + OI, SUBST., } \\
\text { mi [as moongo] }\end{array}$ & II, 230 \\
\hline 162 & mpambu & n. cl. 9 & bifurcation & $\begin{array}{l}\text { PaB + OI, SUBST., u } \\
\text { [as mpaambu] }\end{array}$ & II, 145 \\
\hline 163 & $\| m p e m b a$ & n. cl. 9 & $\begin{array}{l}\text { white clay (used to } \\
\text { whitewash) }\end{array}$ & $\begin{array}{l}\text { PeB + OI, SUBST., zi } \\
\text { [as mpeemba] }\end{array}$ & II, 146 \\
\hline 164 & mpímbidi & n. cl. 9 & $\begin{array}{l}\text { flower of the } \\
\text { banana tree }\end{array}$ & PiB + OI, SUBST., zi & II, 146 \\
\hline 165 & $\| m p u k u$ & n. cl. 9 & rat & $\begin{array}{l}\text { PuK + OII, SUBST., } \\
z i, u\end{array}$ & II, 177 \\
\hline 166 & \|mputulukesi & n. cl. 1 & Portuguese & $\begin{array}{l}\text { PuT + OII, SUBST., } \\
\text { zi }\end{array}$ & II, 214 \\
\hline 167 & ||muánga & n. cl. 3 & sting, venom & $\begin{array}{l}\text { MaG + WI, SUBST., } \\
\text { mi [as mmwaanga] }\end{array}$ & II, 227 \\
\hline 168 & muila & n. cl. 3 & estuary & $\begin{array}{l}\text { MiD \& MiL + OII, } \\
\text { V.DER., iLA [as } \\
\text { mwiidila, mwiila] }\end{array}$ & II, 234 \\
\hline 169 & ||mumpani & n. cl. 3 & pagan, heathen & PaN + O, SUBST., mi & II, 215 \\
\hline 170 & mungwalanga & n. cl. 3 & any tall tree & - & - \\
\hline 171 & \|muéso & n. cl. 3 & whistling & - & $\begin{array}{l}\text { - [as } m u- \\
\text { mpyooso on } \\
\text { p. II, 225] }\end{array}$ \\
\hline 172 & moubi, mouya & n. cl. 3 & $\begin{array}{l}\text { excellent rattan to } \\
\text { weave baskets }\end{array}$ & VuY + SUBST., zi & II, 628 \\
\hline 173 & $\| m v u t u$ & n. cl. 9 & return, answer & $\begin{array}{l}\text { VuT + OII, SUBST., } \\
\text { zi }\end{array}$ & II, 272 \\
\hline 174 & mvwototo & n. cl. 9 & plain (food) & - & - \\
\hline 175 & ||nánama & v. m. & $\begin{array}{l}\text { be tight, tall and } \\
\text { thin }\end{array}$ & $\begin{array}{l}\mathrm{NaN}+\mathrm{O}, \text { V.DER., } \\
\text { aMA }\end{array}$ & II, 123 \\
\hline 176 & nangimisa & v. caus. & $\begin{array}{l}\text { to bother, to offend, } \\
\text { to annoy }\end{array}$ & $\begin{array}{l}\text { NaG + OI, V.DER., } \\
\text { uMA }\end{array}$ & II, 502 \\
\hline
\end{tabular}


http://lexikos.journals.ac.za

The Lexique kikongo-français by Charles Polis (1938)

\begin{tabular}{|c|c|c|c|c|c|}
\hline 177 & \|ndala & n. cl. 9 & $\begin{array}{l}\text { palm leaf; sleep; } \\
\text { alarm }\end{array}$ & DaL + O, SUBST., zi & II, 88 \\
\hline 178 & ndédila & n. cl. 9 & strip of cloth/paper & - & $\begin{array}{l}\text { - [other } \\
\text { word: } \\
\text { nzyaadi on p. } \\
\text { II, 572] }\end{array}$ \\
\hline 179 & ||ndíkila & n. cl. 9 & $\begin{array}{l}\text { action to feed with; } \\
\text { poison }\end{array}$ & $\begin{array}{l}\text { DiK + OII, V.DER., } \\
\text { iLA }\end{array}$ & II, 457 \\
\hline 180 & ndoka & n. cl. 9 & rain & $\begin{array}{l}\text { DoK \& LoK + OII, } \\
\text { SUBST., zi }\end{array}$ & II, 458 \\
\hline 181 & $\| n d \hat{u} k a$ & n. cl. 9 & caution, care; stink & $\begin{array}{l}\text { DuK \& LuK + OII, } \\
\text { SUBST., zi [as } \\
\text { nduuka] }\end{array}$ & II, 460 \\
\hline 182 & ndwanisa & n. $\mathrm{cl} .9$ & attack & - & - \\
\hline 183 & $\| n g a n d u$ & n. cl. 9 & crocodile & $\begin{array}{l}\text { GaD + OI, SUBST., } \\
\text { zi [as ngaandu] }\end{array}$ & II, 335 \\
\hline 184 & ngau, ngawa & n. cl. 9 & palm tree bird & au (monosyllabic) & II, 644 \\
\hline 185 & $\| n g o$ & n. cl. 9 & leopard & Go + O, SUBST., zi & II, 52 \\
\hline 186 & ngonda & $\begin{array}{l}\text { n. cl. 9; } \\
\text { adj. }\end{array}$ & murder; bloody & - & $\begin{array}{l}\text { - [but } \\
\text {-goonda 'to } \\
\text { kill' is in, p. II, } \\
338 \text { ] }\end{array}$ \\
\hline 187 & $\| n g u k a$ & n. cl. 3 & caterpillar & $\begin{array}{l}\text { GuK + OII, SUBST., } \\
\text { mi [as } n n g u k a]\end{array}$ & II, 325 \\
\hline 188 & ngunsa & n. cl. 1 & prophet & - & - \\
\hline 189 & \|niakuna & v. tr. & to chew & $\mathrm{N}-\mathrm{k}+\mathrm{YII}$ & I, 55 \\
\hline 190 & niémita & v. tr. & to pinch & $\begin{array}{l}\text { NeM + Y, V.DER., } \\
\text { iTA [as nyeemita] }\end{array}$ & II, 498 \\
\hline 191 & $\|$ nioka & n. cl. 9 & snake & $\begin{array}{l}\text { NoK + YII, SUBST., } \\
\text { zi [as nyoka] }\end{array}$ & II, 512 \\
\hline 192 & nkâdidi & $\begin{array}{l}<\mathrm{v} . \\
\text { (pret. < } \\
\text { kala) }\end{array}$ & $\begin{array}{l}\text { I denied; I don't } \\
\text { want }\end{array}$ & $\begin{array}{l}\mathrm{KaD} \& \mathrm{KaL}+\mathrm{OII}, \\
\text { VERBE }\end{array}$ & II, 349 \\
\hline 193 & ||nkama & n. cl. 9 & $\begin{array}{l}\text { hundred; act of } \\
\text { dyking up; hus- } \\
\text { band/spouse; dyke }\end{array}$ & $\begin{array}{l}\text { KaM + O, SUBST., zi } \\
\& \text { bi \& mi }\end{array}$ & II, 315 \\
\hline 194 & $n k a n g a$ & n. cl. 9 & $\begin{array}{l}\text { hand of bananas; } \\
\text { act of binding; quail }\end{array}$ & $\begin{array}{l}\text { KaG + OI, SUBST., zi } \\
\text { [as nkaanga] }\end{array}$ & II, 329 \\
\hline 195 & \|nkási & n. cl. 9 & $\begin{array}{l}\text { fraction of a num- } \\
\text { ber }\end{array}$ & $\begin{array}{l}\text { KaZ \& KaS + OII, } \\
\text { SUBST., mi [as } \\
\text { nnkasi] }\end{array}$ & II, 398 \\
\hline 196 & $n k e f o, n k e f u a$ & n. cl. 9 & spicy (pepper) & $\begin{array}{l}\text { KeF + OII, SUBST., } \\
\text { zi }\end{array}$ & II, 322 \\
\hline 197 & \|nkeni(a) & n. cl. 9 & corn & KeN + O, SUBST., zi & II, 388 \\
\hline
\end{tabular}




\begin{tabular}{|c|c|c|c|c|c|}
\hline 198 & nkila & n. cl. 3 & tail & $\begin{array}{l}\text { KiD \& KiL + OII, } \\
\text { SUBST., mi [as } \\
\text { nnkila] }\end{array}$ & II, 361 \\
\hline 199 & ||nkókila & n. cl. 9 & $\begin{array}{l}\text { evening; cock's } \\
\text { singing; act of } \\
\text { attracting with a } \\
\text { hook }\end{array}$ & $\begin{array}{l}\text { KoK + OII, V.DER., } \\
\text { iLA [as nkookila] }\end{array}$ & II, 77 \\
\hline 200 & nkondi & $\begin{array}{l}\text { n. cl. } 1 \& \\
\text { 9; n. cl. } 9\end{array}$ & hunter; fetish & $\begin{array}{l}\text { KoD \& KoL + OI, } \\
\text { SUBST., zi [as } \\
\text { nkoondi] }\end{array}$ & II, 363 \\
\hline 201 & $\| n k u f i$ & n. cl. 9 & salutation & $\begin{array}{l}\text { KuF + OII, SUBST., } \\
\text { ma [as makufi, kufi] }\end{array}$ & II, 322 \\
\hline 202 & nkumba & n. cl. 3 & navel & $\begin{array}{l}\text { KuB + OI, SUBST., } \\
\text { mi [as nnkumba] }\end{array}$ & II, 308 \\
\hline 203 & $\| n k u s u$ & n. cl. 9 & parrot & $\begin{array}{l}\text { KuS + OII, SUBST., } \\
\text { zi }\end{array}$ & II, 405 \\
\hline 204 & $n k w a m u$ & $\begin{array}{l}\text { n. cl. 9; } \\
\text { adj. }\end{array}$ & $\begin{array}{l}\text { duration; continu- } \\
\text { ous }\end{array}$ & $\begin{array}{l}\text { KaM + W, SUBST., } \\
\text { tu [as lukwaamu] }\end{array}$ & II, 315 \\
\hline 205 & \|nlele & n. cl. 3 & $\begin{array}{l}\text { cloth, pagne made } \\
\text { out of cloth }\end{array}$ & $\begin{array}{l}\text { LeL + OII, SUBST., } \\
\text { mi [as nnleele] }\end{array}$ & II, 95 \\
\hline 206 & nluku & n. cl. 3 & young breasts & $\begin{array}{l}\text { DuK \& LuK + OII, } \\
\text { SUBST., ? [as nnluku] }\end{array}$ & II, 460 \\
\hline 207 & $\| n s a$ & n. cl. 9 & greyish antelope & Sa + O, SUBST., zi & II, 135 \\
\hline 208 & nsaku & n. cl. 9 & old thing & - & - \\
\hline 209 & $\begin{array}{l}\text { Insampatu, } \\
\text { nsampitu, } \\
\text { nsamputu }\end{array}$ & n. cl. 9 & shoe & - & $\begin{array}{l}\mathrm{Y} \text { [and } \\
\text { nsabaatu is } \\
\text { also in, p. II, } \\
\text { 529] }\end{array}$ \\
\hline 210 & nsau & n. cl. 9 & pilot, ferryman & Sau + mi [as nnsau] & II, 137 \\
\hline 211 & $\| n s i$ & n. cl. 9 & $\begin{array}{l}\text { floor, region, coun- } \\
\text { try }\end{array}$ & Si + O, SUBST., zi & II, 136 \\
\hline 212 & nsila moula & n. cl. 9 & heavy rain & - & - \\
\hline 213 & $\| n s o k i$ & $\begin{array}{l}\text { n. cl. } 3 ; \mathrm{n} . \\
\text { cl. } 9\end{array}$ & $\begin{array}{l}\text { mistake; ramrod; } \\
\text { long type of grass }\end{array}$ & $\begin{array}{l}\text { SoK + OII, SUBST., } \\
\text { mi \& tu [as nnsoki \& } \\
\text { lusoki] }\end{array}$ & II, 569 \\
\hline 214 & nsóngisa & n. cl. 9 & act of redressing & - & $\begin{array}{l}\text { - [but base } \\
\text { verb soonga } \\
\text { 'to be } \\
\text { straight' is } \\
\text { in, p. II, 559] }\end{array}$ \\
\hline 215 & $\| n s u k a$ & n. cl. 9 & end & $\begin{array}{l}\text { SuK + OII, SUBST., } \\
\text { zi }\end{array}$ & II, 571 \\
\hline 216 & nsungu & n. cl. 9 & worry & - & $\begin{array}{l}\text { - [but base } \\
\text { verb suunga }\end{array}$ \\
\hline
\end{tabular}




\begin{tabular}{|c|c|c|c|c|c|}
\hline & & & & & $\begin{array}{l}\text { 'to worry } \\
\text { about' is in, } \\
\text { p. II, 560] }\end{array}$ \\
\hline 217 & $\| n s w a l u$ & n. cl. 3 & speed & $\begin{array}{l}\text { SaL \& SaD + OII, } \\
\text { SUBST., mi [as } \\
\text { nnswaala] }\end{array}$ & II, 581 \\
\hline 218 & ntamba & n. cl. 9 & offer & - & $\begin{array}{l}\text { - [but verb } \\
\text { is in, p. II, } \\
419 \text { ] }\end{array}$ \\
\hline 219 & $\| n t e b a$ & n. cl. 9 & mud & $\begin{array}{l}\text { TeB + OII, SUBST., } \\
\text { zi }\end{array}$ & II, 425 \\
\hline 220 & nteti-mbisi & n. cl. 1 & butcher & - & - \\
\hline 221 & $\begin{array}{l}\text { \|ntomboka, } \\
\text { ntombuka }\end{array}$ & n. cl. 9 & ascension & - & $\begin{array}{l}\mathrm{Y} \text { [p. II, 314; } \\
\text { and verb is } \\
\text { in, p. II, 426] }\end{array}$ \\
\hline 222 & ntoya & n. cl. 9 & $\begin{array}{l}\text { bird of the banana } \\
\text { tree }\end{array}$ & ToY + O, SUBST., zi & II, 632 \\
\hline 223 & $\| n t \hat{t} t u$ & n. cl. 3 & bottle; opening & $\begin{array}{l}\text { TuT + OII, SUBST., } \\
\text { mi [as nntuutu] }\end{array}$ & II, 117 \\
\hline 224 & $\begin{array}{l}\text { nungumuka, } \\
\text { nungumuna }\end{array}$ & v. tr. & to push hard & $\begin{array}{l}\text { NuG + OI, V.DER., } \\
\text { uMA }\end{array}$ & II, 508 \\
\hline 225 & ||nyalu & n. cl. 9 & row, layer & $\begin{array}{l}\text { YaD \& YaL + II, } \\
\text { SUBST., zi }\end{array}$ & II, 617 \\
\hline 226 & nzalala & n. cl. 9 & haste & $\begin{array}{l}\text { ZaD \& ZaL + OII, } \\
\text { V.DER., aLA [as } \\
\text { zalala] }\end{array}$ & II, 574 \\
\hline 227 & $\| n z a z a$ & n. cl. 9 & vessel, ship & $\begin{array}{l}\mathrm{ZaZ}+\text { OI, SUBST., zi } \\
\text { [as nzaanza] }\end{array}$ & II, 127 \\
\hline 228 & nzikisa & n. $\mathrm{cl} .9$ & check, proof & - & $\begin{array}{l}\text { - [but verb } \\
\text { is in, p. II, } \\
552 \text { ] }\end{array}$ \\
\hline 229 & $\| n z o$ & n. cl. 9 & house & Zo + O, SUBST., zi & II, 126 \\
\hline 230 & $\begin{array}{l}\text { nzo zi matubu } \\
\text { tatu }\end{array}$ & n. cl. 10 & $\begin{array}{l}\text { two pagnes sewn } \\
\text { together }\end{array}$ & $\begin{array}{l}\text { Zo + O, SUBST., zi } \\
\text { [as nzo tubu] \& TuB + } \\
\text { OII, SUBST., ? [as } n z o \\
t u b u \text { ] }\end{array}$ & $\begin{array}{l}\text { II, } 126 \& \text { II, } \\
429\end{array}$ \\
\hline 231 & $\| n z u z i$ & n. cl. 9 & "tiger cat" & $\begin{array}{l}\text { ZuZ + OII, SUBST., } \\
\text { zi }\end{array}$ & II, 132 \\
\hline 232 & pala & v. i. & to make jealous & PaL + OII, VERBE & II, 204 \\
\hline 233 & $\|$ pii, pidi & n. cl. 5 & silence & $\mathrm{Pi}+\mathrm{O} ; \mathrm{P}-\mathrm{d}, \mathrm{OII}$ & $\mathrm{I}, 5 ; \mathrm{I}, 34$ \\
\hline 234 & pupula & v. i. & to stay up & - & - \\
\hline 235 & $\| s a b i$ & n. cl. 5 & cork & $\begin{array}{l}\text { SaB + OII, SUBST., } \\
\text { zi [as nsabi] }\end{array}$ & II, 528 \\
\hline 236 & sakula & v. tr. & to weed & $\begin{array}{l}\text { SaK + OII, V.DER., } \\
\text { uLA }\end{array}$ & II, 564 \\
\hline
\end{tabular}




\begin{tabular}{|c|c|c|c|c|c|}
\hline 237 & \|sampula & v. tr. & to carry over & $\begin{array}{l}\text { SaP + OI, V.DER., } \\
\text { uLA [as saampula] }\end{array}$ & II, 533 \\
\hline 238 & sangalakasa & v. i. & to mix & - & $\begin{array}{l}\text { — [but base } \\
\text { verb -saanga } \\
\text { 'to mix' is in, } \\
\text { p. II, 554] }\end{array}$ \\
\hline 239 & \|sasuka & v. m. & to hurry & $\begin{array}{l}\text { SaS + OII, V.DER., } \\
\text { u-- }\end{array}$ & II, 140 \\
\hline 240 & seke, seki & n. cl. 5 & small bush sparrow & $\begin{array}{l}\text { SeK + OII, SUBST., } \\
\text { ma }\end{array}$ & II, 466 \\
\hline 241 & \|sénguka & v. m. & $\begin{array}{l}\text { be put face-up, be } \\
\text { discovered }\end{array}$ & $\begin{array}{l}\text { SeG + OI, V.DER., } \\
\text { uKA [as seenguka] }\end{array}$ & II, 557 \\
\hline 242 & siatunina & v. rel. & to inject in & - & $\begin{array}{l}\text { - [but verb } \\
\text {-syatula 'to } \\
\text { spurt out' is } \\
\text { in, p. II, 590] }\end{array}$ \\
\hline 243 & $\| \operatorname{simba}$ & v. tr. & to hold & SiB + OI, VERBE & II, 530 \\
\hline 244 & síngamísa & v. caus. & $\begin{array}{l}\text { to make sure st. is } \\
\text { straight }\end{array}$ & - & $\begin{array}{l}\text { - [but verb } \\
\text {-siingama 'to } \\
\text { be straight' is } \\
\text { in, p. II, 558] }\end{array}$ \\
\hline 245 & || sókama & v. m. & be rare & - & - \\
\hline 246 & sómbuka & v. m. & to jump & $\begin{array}{l}\text { SoB + OI, V.DER., } \\
\text { uKA [as soombuka] }\end{array}$ & II, 531 \\
\hline 247 & \|sótuka & v. m. & to get lost & $\begin{array}{l}\text { SoT + OII, V.DER., } \\
\text { uKA }\end{array}$ & II, 592 \\
\hline 248 & sukulu & n. cl. 5 & $\begin{array}{l}\text { corner behind the } \\
\text { door }\end{array}$ & - & - \\
\hline 249 & \|sumuka & v. m. & $\begin{array}{l}\text { to transgress, to } \\
\text { commit a sin }\end{array}$ & $\begin{array}{l}\text { SuM + O, V.DER., } \\
\text { uKA }\end{array}$ & II, 540 \\
\hline 250 & sunsimika & v. tr. & to swallow whole & - & - \\
\hline 251 & \|swétama & v. m. & be thin, be narrow & $\begin{array}{l}\text { SeT, WII, V.DER., } \\
\text { aMA [as sweetama] }\end{array}$ & II, 591 \\
\hline 252 & taka & n. cl. 7 & $\begin{array}{l}\text { fork (used to hold } \\
\text { thieves) }\end{array}$ & $\begin{array}{l}\text { TaK + OII, SUBST., } \\
\text { ma }\end{array}$ & II, 467 \\
\hline 253 & ||táluka & v. m. & be spread & $\begin{array}{l}\text { TaL + OII, V.DER., } \\
\text { uKA }\end{array}$ & II, 481 \\
\hline 254 & tanda-tanda & n. cl. 7 & $\begin{array}{l}\text { extreme thinness, } \\
\text { wasting away }\end{array}$ & $\begin{array}{l}\text { TaD \& TaL + OI, } \\
\text { SUBST., mu }\end{array}$ & II, 478 \\
\hline 255 & $\|$ tâta & n. cl. 1 & father; chief & $\begin{array}{l}\text { TaT + OII, SUBST., } \\
\text { ba [as taata] }\end{array}$ & II, 111 \\
\hline 256 & tebisa & v. caus. & to fill to the brim & - & Y [p. II, 574] \\
\hline 257 & \|teluka & v. m. & $\begin{array}{l}\text { be removed from } \\
\text { the fire }\end{array}$ & $\begin{array}{l}\text { TeL + OII, V.DER., } \\
\text { uKA }\end{array}$ & II, 483 \\
\hline
\end{tabular}


http://lexikos.journals.ac.za

The Lexique kikongo-français by Charles Polis (1938)

\begin{tabular}{|c|c|c|c|c|c|}
\hline 258 & tengama & v. m. & $\begin{array}{l}\text { to accumulate (in a } \\
\text { pool of water) }\end{array}$ & $\begin{array}{l}\text { TeG + OI, V.DER., } \\
\text { aMA }\end{array}$ & II, 463 \\
\hline 259 & $\|$ tiaka & v. tr. & to spill, to pour & $\begin{array}{l}\text { TaK + YII, VERBE [as } \\
\text { tyaaka] }\end{array}$ & II, 467 \\
\hline 260 & tikita & n. cl. 5 & knife & $\begin{array}{l}\text { TiK + OII, V.DER., } \\
\text { iTA }\end{array}$ & II, 471 \\
\hline 261 & $\|$ titila & v. rel. & $\begin{array}{l}\text { to shake because of, } \\
\text { to be afraid of }\end{array}$ & - & $\begin{array}{l}\text { - [but base } \\
\text { verb -tiita 'to } \\
\text { tremble' is } \\
\text { in, p. II, 115] }\end{array}$ \\
\hline 262 & tokolo & n. cl. 5 & jaw & $\begin{array}{l}\text { ToK + OII, V.DER., } \\
\text { aLA [as matookolo] }\end{array}$ & II, 472 \\
\hline 263 & \|tona & v. i. & to understand & - & Y [p. II, 490] \\
\hline 264 & tótakána & v. i. & to converge & - & - \\
\hline 265 & $\|$ tubuka & v. m. & be pierced & $\begin{array}{l}\text { TuB + OII, V.DER., } \\
\text { uKA }\end{array}$ & II, 429 \\
\hline 266 & túkula, dukula & v. i. & to move, to shake & $\begin{array}{l}\text { TuK + OII, V.DER., } \\
\text { uLA }\end{array}$ & II, 474 \\
\hline 267 & \|tumbuka & v. m. & $\begin{array}{l}\text { to manifest; to stop } \\
\text { dripping }\end{array}$ & $\begin{array}{l}\text { TuB + OI, V.DER., } \\
\text { uKA [as tuumbuka] }\end{array}$ & II, 428 \\
\hline 268 & tungalakala & v. i. & $\begin{array}{l}\text { to interlace, to } \\
\text { intertwine }\end{array}$ & - & $\begin{array}{l}\text { - [but verb } \\
\text { tungalaka is } \\
\text { in, p. II, 466] }\end{array}$ \\
\hline 269 & $\| t u t i$ & n. cl. 5 & cloud & $\begin{array}{l}\text { TuT + OII, SUBST., } \\
\text { ma }\end{array}$ & II, 117 \\
\hline 270 & twenga & n. cl. 5 & young shoot & $\begin{array}{l}\text { TeG + WI, SUBST., } \\
\text { bi [as tweengi] }\end{array}$ & II, 463 \\
\hline 271 & \|uele & $<\mathrm{v}$ & he/she is gone & - & $\mathrm{Y}$ \\
\hline 272 & vika & v. aux. & $\begin{array}{l}\text { (marks an immi- } \\
\text { nent action) }\end{array}$ & ViK + OII, VERBE & II, 256 \\
\hline 273 & \|vitika & v. tr. & to lower, to bow & $\begin{array}{l}\text { ViT + OII, V.DER., } \\
\text { iKA }\end{array}$ & II, 272 \\
\hline 274 & vúmana & v. rec. & $\begin{array}{l}\text { to respect one } \\
\text { another }\end{array}$ & - & $\begin{array}{l}\text { - [but noun } \\
\text { luvuma } \\
\text { 'respect' is } \\
\text { in, p. II, 249] }\end{array}$ \\
\hline 275 & ||vunga & n. cl. 5 & any cover & $\begin{array}{l}\text { VuG + OI, SUBST., } \\
\text { ma [as vuunga] }\end{array}$ & II, 255 \\
\hline 276 & vúzana & v. i. & $\begin{array}{l}\sim \operatorname{mbundu}=\text { to feel } \\
\text { nauseous }\end{array}$ & $\begin{array}{l}\text { VuZ \& VuS + OI, } \\
\text { V.DER., aNA [as } \\
\text { vuunzana] }\end{array}$ & II, 290 \\
\hline 277 & $\begin{array}{l}\text { |lvwansa, } \\
\text { vwanza }\end{array}$ & v. i. & $\begin{array}{l}\text { to damage, to oblit- } \\
\text { erate, to dirty }\end{array}$ & $\begin{array}{l}\text { VaZ \& VaS, WI, } \\
\text { VERBE [as vwaanza] }\end{array}$ & II, 288 \\
\hline
\end{tabular}




\begin{tabular}{|c|c|c|c|c|c|}
\hline 278 & $w a$ & v. tr. & $\begin{array}{l}\text { to hear; to under- } \\
\text { stand; (completed } \\
\text { action) }\end{array}$ & Wa, VERBE & II, 634 \\
\hline 279 & \|wena & v. i. & to stop, to leave & $\begin{array}{l}\text { WeN + VERBE [as } \\
\text { weena] }\end{array}$ & II, 640 \\
\hline 280 & yabakana & v. rec. & $\begin{array}{l}\text { to talk a lot } \\
\text { amongst one } \\
\text { another }\end{array}$ & - & - \\
\hline 281 & |lyálumuna & v. tr. & to unroll, to spread & $\begin{array}{l}\text { YaD \& YaL + II, } \\
\text { V.DER., uMA }\end{array}$ & II, 618 \\
\hline 282 & yanga & v. tr. & to heat & YaG + I, VERBE & II, 609 \\
\hline 283 & Iyaya & n. cl. 1 & grandmother & $\begin{array}{l}\text { YaY + OII, SUBST., } \\
\text { ba }\end{array}$ & II, 601 \\
\hline 284 & yekikila & v. tr. & $\begin{array}{l}\text { to stand/lean } \\
\text { against st. }\end{array}$ & $\begin{array}{l}\text { YeK + II, V.DER., } \\
\text { iKA [as 'to stop; to } \\
\text { keep'] }\end{array}$ & II, 614 \\
\hline 285 & $\|$ yemba & v. tr. & to steal & $\begin{array}{l}\text { YeB + I, VERBE [as } \\
\text { yeemba 'to leave'] }\end{array}$ & II, 605 \\
\hline 286 & yensula & v. tr. & to open wide & - & - \\
\hline 287 & Iyikama & v. m. & be added & $\begin{array}{l}\text { YiK + II, V.DER., } \\
\text { aMA }\end{array}$ & II, 615 \\
\hline 288 & yindumuna & v. rev. & to make forget & - & - \\
\hline 289 & $\|$ yobila & v. i. & to take a bath & $\begin{array}{l}\text { YoB + II, V.DER., } \\
\text { iLA }\end{array}$ & II, 606 \\
\hline 290 & yukula & v. i. & $\begin{array}{l}\text { to make light with a } \\
\text { torch }\end{array}$ & - & $\begin{array}{l}\text { - [but a } \\
\text { homonym is } \\
\text { in, p. II, 616] }\end{array}$ \\
\hline 291 & |lyúngana & v. i. & to wander & $\begin{array}{l}\text { YuG + I, V.DER., } \\
\text { aNA }\end{array}$ & II, 613 \\
\hline 292 & zakila, zakimina & v. rel. & to tremble & $\begin{array}{l}\text { ZaK + OII, V.DER., } \\
\text { aMA }\end{array}$ & II, 549 \\
\hline 293 & $\| z a u l a$ & v. tr. & to draw, to pump & $\begin{array}{l}\text { au (polysyllabic) + } \\
\text { Z-L }\end{array}$ & II, 645 \\
\hline 294 & $\begin{array}{l}\text { zeleniana, } \\
\text { zelengana, } \\
\text { zelangana }\end{array}$ & v. i. & $\begin{array}{l}\text { be exhausted, be } \\
\text { weak }\end{array}$ & $\begin{array}{l}\text { ZeD \& ZeL + OII, } \\
\text { V.DER., aNGA [as } \\
\text {-zelangana] }\end{array}$ & II, 575 \\
\hline 295 & \|zíama & v. m. & be buried & $\begin{array}{l}\text { ZaM + Y, VERBE [as } \\
\text { zyaama] }\end{array}$ & II, 535 \\
\hline 296 & $z i k u-z i k u$ & adv. & just & $\begin{array}{l}\text { ZiK + OII, VARIA } \\
\text { [as ziku ziku] }\end{array}$ & II, 551 \\
\hline 297 & ||zingisa & v. caus. & $\begin{array}{l}\text { to make last, to } \\
\text { make live }\end{array}$ & - & $\begin{array}{l}\text { — [but base } \\
\text { verb is in, } p \text {. } \\
\text { II, 545] }\end{array}$ \\
\hline
\end{tabular}


http://lexikos.journals.ac.za

The Lexique kikongo-français by Charles Polis (1938)

\begin{tabular}{|c|c|c|c|c|c|}
\hline 298 & ziúngalakána & v. i. & $\begin{array}{l}\text { to whirl around, to } \\
\text { surround }\end{array}$ & $\begin{array}{l}\text { ZuG + YI, V.DER., } \\
\text { aLA [as -zyunga- } \\
\text { lakana] }\end{array}$ & II, 547 \\
\hline 299 & ||zole & num. & two & - & $\mathrm{Y}$ \\
\hline 300 & $z u n d u$ & n. cl. 5 & giant frog & $\begin{array}{l}\text { ZuD \& ZuL + OI, } \\
\text { SUBST., ma [as } \\
\text { zuundu] }\end{array}$ & II, 577 \\
\hline 301 & \|babila & v. tr. & $\begin{array}{l}\text { to flap, to flutter; to } \\
\text { dance }\end{array}$ & $\begin{array}{l}\text { BaB + OII, V.DER., } \\
\text { iLA }\end{array}$ & II, 10 \\
\hline 302 & bondengila & v. i. & $\begin{array}{l}\text { to resonate far } \\
\text { away }\end{array}$ & - & - \\
\hline 303 & $\|$ dombo & n. cl. 5 & $\begin{array}{l}\text { a single bar of brass } \\
\text { (which serves as } \\
\text { money) }\end{array}$ & - & - \\
\hline 304 & gakula & v. tr. & to deceive & - & $\begin{array}{l}\text { - [but a } \\
\text { homonym is } \\
\text { in, p. II, 323] }\end{array}$ \\
\hline 305 & $\| k i b i d i$ & n. cl. 7 & $\begin{array}{l}\text { place where one } \\
\text { rets (soaks) manioc }\end{array}$ & - & - \\
\hline 306 & kintuku & n. cl. 7 & charm, fetish & - & - \\
\hline 307 & \|sunguta & v. i. & to $\operatorname{limp}$ & $\begin{array}{l}\text { SuG + OI, V.DER., } \\
\text { uTA [as suunguta] }\end{array}$ & II, 561 \\
\hline 308 & vonga, fonga & v. i. & $\begin{array}{l}\text { to sit oneself, be } \\
\text { seated }\end{array}$ & VoG + OI, VERBE & II, 254 \\
\hline
\end{tabular}

- Abbreviations in the POS (part of speech) column, using Butaye's terminology: <= derived from ...; adj. = adjective; $a d v .=$ adverb; affirm. = affirmative; $a u x .=$ auxiliary; caus. $=$ causative $(-$ is-) $; c l .=$ class; conj. $=$ conjunction; dem. $=$ demonstrative; $\operatorname{dim} .=$ diminutive; $i$. $=$ intransitive; $i n v .=$ invariable; $m .=-\mathrm{uk}-,-\mathrm{am}-; n .=$ noun; $n u m .=$ numeral; part. $=$ particle; poss. $=$ possibility $(-$ akan-); pref. $=$ prefix $;$ prep.$=$ preposition; pret. $=$ preterite; pron . $=$ pronoun; quest. $=$ question; rec. $=$ reciprocal $(-$ an- $) ;$ refl. $=$ reflexive $(\mathrm{ki}-, \mathrm{i}-) ;$ rel. $=$ relative (-il-, -in-); rev. = reversive (-un-); tr. = transitive; $v$. = verb.

- The noun class numbers in the POS column reflect those of Butaye (and include errors), but were transposed to their modern equivalents.

- In the last column $\mathrm{Y}=$ yes, meaning that while the word may not be an item, it is still used in Polis. 